\title{
DENISE CASATT
}

\section{Viagem ao outro Um estudo sobre o encontro entre jomalista se fontes}

Dissertação a presentada à Área de Concentração Jomalismo e Editoração da Escola de Comunicações e Artes da Universidade de São Paulo, como exigência parcial para obtenção do Título de Mestre em Ciências da Comunicação, sob orientação do Prof. Dr. Edvaldo Pereira Lima.

São Paulo

2006 


\section{DENISE CASATT}

\section{Viagem ao outro \\ Em busca de um encontro genuíno entre jomalistase fontes}

Dissertação a presentada à Área de Concentração Jomalismo e Editoração da Escola de Comunicações e Artes da Universidade de São Paulo, como exigência parcial para obtenção do Título de Mestre em Ciências da Comunicação, sob orientação do Prof. Dr. Edvaldo Pereira Lima.

São Paulo

2006 
DEFESA DA DISSERTAÇÃo VIAGEM AO OUTRO - UM ESTUDO SOBRE O ENCONTRO ENIREJ ORNAUSTAS E FONTES, DE DENISE C ASATTI

BANCA J ULGADORA

PROF. DR. EDVALDO PEREIRA LMA ORIENTADOR

SÃo PAULO (SP), DE DE 2006. 
Para

minha mãe Elza, meu pai Arlindo e

à força iluminadora que me permitiu estar aqui. 


\section{AgRADECIMENIOS}

Ao professor Edvaldo Pereira Lima, meu mentor nessa jomada de crescimento acadêmico e existencial;

A toda a minha família pelo apoio fundamental: Elza, Arlindo, J osé Carlos, Ronaldo, Cláudio, Sônia e Karina. Em especial aos meus a ma dos sobrinhos pela inspiração gra ciosa: Heloísa, Jady, Daniel e Ana Luíza;

A minha imã de coração, Carla Cristina Bojorque, interlocutora durante a escritura desta tese;

Aos colegas da estrada do J oma lismo Literário Avançado, pelos conselhos e idéias trocados ao longo de nossas reuniões, em especial Mônica Martinez (pela graça de me indicara leitura de Opening Up) e Renata Carraro;

Aos amigos que não faltaram nos últimos minutos desta tese: William Goulart da Silva, Déborah Heloísa Motooka, Thays Tateoka e a todos os outros que não cito nominalmente, mas que sempre estão por perto.

A Cláudia Bava Shinyashiki, Rosely Shinyashiki Boschini, Anderson Cerqueira Cavalcante e Margaret Miraglia por seus preciosos depoimentos.

A Roberto Shinyashiki por compartilhar sua história e pelo apoio fundamental no percurso final desta jomada.

E a todos as pessoas que um dia confiaram em mim e me relatam suas histórias. 


\section{RESUMO}

Esta dissertação discute os fenômenos que ocorrem na troca entre os jomalistas e as pessoas que namam suas histórias a eles. Ao lançar luzes sobre a viagem que cada um desses sujeitos pode fazer a partir daí, a hipótese é de que uma relação mais próxima entre jomalistas e fontes favorece a construção de uma narrativa diferenciada, que pode, inclusive, atingir um patamar artístico literário. Acompanhando a reflexão teórica, a presento uma narrativa experimental que fiz e resultou na elaboração de um perfil, seguindo as especificações do Jomalismo Literánio Avançado. Realizo deduções e reflexões, tendo como âncora o experimento de campo, buscando trazer contribuições para a prática jomalística. Por isso, a Dissertação é um trabalho qualitativo, com certo grau de característica fenomenológica. Respeitando as esferas próprias de atuação do jomalismo, busco apoiar a reflexão teónica em conceitos da filosofia, da psicologia e da estética. Proponho também que essa questão seja abordada de maneira mais consistente nos cursos de graduação, durante o processo de formação dosfuturos jomalistas.

\section{Palavras-chave}

Intersubjetividade - Jomalismo - Transformação - Fenomenologia - Jomalismo Literário Avançado

\section{ABSTRACT}

This essay disc usses the phenomena which take place on exchanges between joumalists and those who tell them their own stories. On casting a light upon the joumey that each of these individuals may make from thereon, the hypothesis is that a closer bond between joumalists and their sources favours the building of a narrative of distinction, which may also reach a literary artistic level. Following the theoretic al reflections, I hereby present a n experimental na rative I have written and which lead to the establishment of a profile in accordance with the specifications of Advanced Literary Joumalism. I have made deductions and reflections based on the field study, seeking to bring contributions to the practise of joumalism. The essay have the aspect of a qualitative study with some degree of phenomenological cha racteristics. Respecting the spheres pertinent to the conduction of joumalism, this essay seeks to uphold the theoretical reflection in philosophical, psychological and aesthetic concepts. I have also proposed that this question be addressed in the most in consistent manner in jouma lism courses, in the development process of future jouma lists.

\section{KEYWORDS}

Intersubjec tivity - J ouma lism - Tra nformation - Adva nced Litera ry J oumalism 


\section{SUMÁRIO}

\section{Antes do embarque}

De olho nos pilares corroídos

De olho nas possibilidades_ 14

Um encontro com a história__ 17

Um encontro com a antropologia 19

Um encontro com a mitologia__ 20

Um encontro com a sociologia___ 21

De olho na estrada__ 22

Uma atitude, um modo de vere reportar 23

Novos contextos, novos rumos 25

Momento da partida: uma narrativa

O homem que não pára_ 30

A cańcia essencial_ 31

O poderda solução__ 35

Os donos do futuro _ 39

Sem medo de vencer 43

O sucesso é serfeliz__ 48

Paise filhos, companheiros de viagem__ 53

Você: a alma do negócio__ 61

Mistérios do coração_ 64

Amarpode darcerto 66

A revolução doscampeões__ 70

Heróis de verdade__ 73

Contribuições encontradas durante a viagem

Berços de um contare de um escutar

Considerações metodológic as___ 83

Contribuições de Martin Buber__ 87

Contribuições de Merleau-Ponty___ 93

Contribuições de Luigi Pareyson__ 98

ContribuiçõesJ a mes W. Pennebaker__ 103

Hora do desembarque__ 110

Referênc ias bibliográficas__ 119 


\section{Antes do embarque}

Antes de começamos esta viagem, sugiro que olhemos atentamente para o ponto de partida. Compreendendo de onde viemos poderemos perceber melhor onde é possível chegare, na hora do desembarque, estaremos prontos para avaliar o que aconteceu durante o trajeto.

Se de fato nos deixamos levar pelas descobertas trazidas ao nos relacionamos com as paisagens, pessoas e emoções que surgem enquanto estamos no caminho, provavelmente voltaremos diferentes. Pois os verdadeiros viajantes, como nos diz a própria palavra que os nomeia, são seres que não estão parados, eles se movem com o mundo que os toca e pelo qual se deixam ser tocados.

Por isso, é sempre bom, antes do embarque, fazer algumas reflexões preliminares. No caso de uma Dissertação de Mestrado, é preciso falar sobre origens teóric as e explic itar em qual paradigma científic o a credita-se estar inserido.

Neste momento em que o ambiente científico convive com uma série de conceitos contraditórios, uma verdadeira crise de paradigmas, muitas noções que parecem óbvias a algumas pessoas soam como absurdas a outras. Nesse contexto complexo, dizer de onde viemos toma-se imprescindível.

\section{De olho nos pilares comoídos}

Se olharmos ao redor dessa estação de embarque chamada jomalismo, veremos que seus tradicionais pilares parecem corroídos. Conceitos, princípios e modelos que vinham sendo utilizados desde que o jomalismo surge como técnica, na virada do século XIX para o século XX, e eram considerados indiscutíveis, passaram a ser amplamente questionados em diversas esferas, especialmente no ambiente acadêmico.

Como se faz durante a construção de qualquer estação, os pilares aqui utilizados chegaram de diversas instâncias para fomar essa ba se de sustentação 
que hoje parece tão abalada. Nesse processo, a busca era por critérios que conferissem maior respeitabilidade a novo campo de conhecimento que estava se formando.

Em sua Tese de Doutorado, "A medida do olhar: objetividade e autoria na reportagem", Rogério Christofoletti faz um verdadeiro retrocesso ao tempo para mostrar a origem dessas ba ses. Ele explica que a expansão capitalista permitiu que se desenvolvesse, nos Estados Unidos e em alguns países da Europa, uma indústria de jomais estruturada para atender à crescente demanda por informações. Assim, foram desenvolvidas novas má quinas e equipa mentos, realiza da uma reengenharia nas plantas dos parques gráfic os e implantada s inúmeras modific ações no processo produtivo das notícias, tais como: padronização de uma série de procedimentos, estabelecimento de uma rotina operacional, definição de linhas editoriais e estruturas básicas para o texto jomalístico etc.

Como conseqüência dessas modificações, surgem os famosos manuais de redação e estilo enquanto consolida-se a pirâmide invertida como um importante padrão de organização das informações.

Alguns padrões de conduta vão se cristalizando entre os jomalistas e isso ajuda na definição de um ethos profissional, no desenho de um perfil mínimo deste trabalhador. Os valores morais e éticos vão emergindo: o apego à verdade, a defesa da liberdade de expressão, a preocupação com a correção da informação, uma atitude perene de desconfiança, um senso crítico frente ao mundo e às pessoas, o compromisso com a fiscalização dos poderes, a independência editorial, um contínuo questionamento sobre as versões e sobre os fatos... (CHRISTOFOLETI, 2004, p. 106)

Olhando com atenção para esses valores e padrões de conduta que vão se estabelecendo, observamosa intensa busca pela certeza, que se tomará uma das obsessões do jomalismo. Configura-se, assim, a crença de que esse novo campo de conhecimento é capaz de transmitir a o público a verdade única de um fato. É essa certeza que possibilitará ao jomalismo se fimar como um campo legítimo de 
tradução do mundo às pessoas. Afinal, tal como a ciência que instituiu a razão, o sujeito e o método científico a partir do séc. XVII, o jomalismo também faz uma rigorosa análise dos fatos, comprovando as diversas versões, de acordo com critérios como a objetividade e a imparcialidade.

Diante disso, não é demais considerar o J omalismo como um signatário do cartesianismo. O Jomalismo nasceu e se desenvolveu no rastro do capitalismo, cresceu alimentado pela forma de vida das sociedades industriais, fortaleceu-se com a organização positivista dos saberes e a madureceu com a implementação de uma racionalidade modema. A raiz cartesiana, portanto, não the é um fardo, é um traço constitutivo da sua natureza. (Ibid., p. 109)

Ou seja, quando analisamos a história da consolidação do jomalismo, compreendemos sua estreita relação com a ciência herdada de Descartes, Bacon, Galileu e Newton. Para compreendemos melhor essa ligação entre jomalismo e ciência, vamos recorrer a o livro "A janela visionária", do físico Amit Goswami, para mostrar quais são os principais dogmas que sustentam o paradigma positivofunc iona lista:

deteminismo causal - "o mundo é uma máquina deteminada, de mecanismo semelhante ao de um relógio" (p. 41);

continuidade - "hipótese de que todo movimento, ou toda mudança, é contínuo" (p. 42);

localidade - princípio que estabelece a impossibilidade de "uma ação simultânea à distância" (p. 42);

objetividade forte - idéia de que o mundo material é independente de nós, observadores;

monismo materialista e reducionismo - noção de que "todo fenômeno tem uma origem material a que pode ser reduzido" ( $p$. 42);

epifenomenalismo - compreensão de que todos os fenômenos subjetivos são fenômenos sec undários da matéria. 
Com esse breve resumo dos dogmas da ciência clássica, percebemos como, baseando-se nessas concepções científicas, construiu-se a idéia de que jomalistas são pessoas capazes de estampar a verdade na mídia. Mas esses dogmas passaram a ser questionados a partir das descobertas da física quântica. E podemos dizer que foi a partir daí que os pilares do jomalismo começaram a ser corroídos.

Em um rápido passeio pelas principais descobertas da física quântica, é fácil perceber como os dogmas da ciência clássica foram caindo por terra. Conforme explica Goswami, a física quântica estuda o comportamento dos átomos, os qua is consistem de elétrons que se movem em tomo de um núcleo a tômico.

De acordo com os primeiros estudos do físico Niels Bohr, no início do século $X X$, um elétron desaparece de uma órbita e reaparece em uma outra, sem percorrer o espaço entre elas. Com essa descoberta, demuba-se o princípio da continuidade.

Goswami relata que, mais de dez anos depois, explicou-se que a capacidade do elétron de saltar órbitas tem origem na sua natureza de onda. Sendo assim, os elétrons foram definidos como ondas de possibilidades. Mas o que significa isso?

Quando nós não estamos observando um elétron atômico, ele se toma, devido à sua interação com o campo eletromagnético, uma superposição de localização em duas (ou mais) órbitas ao mesmo tempo - ainda que em temos de possibilidade. Quando nós observamos o elétron, a possibilidade de que ele esteja em dois (ou mais) lugares se converte no ato de estar momentaneamente em um único lugar... (GOSWAMI, 2003, p. 45)

Ou seja, isso quer dizer que o homem pode prever apenas a probabilidade de o elétron estar em um detemina do local, mas não pode deteminar sua posição exata. Essa descoberta, em conjunto com o Princípio da Incerteza, formulado por Wemer Heisenberg em 1926, nuiu as bases do deteminismo. De acordo com o Princípio da Incerteza, é impossível deteminar a posição e a velocidade de um 
objeto quântico (elemento que é partícula e onda ao mesmo tempo), simultaneamente, com exatidão absoluta.

Outro princípio que a física quântica demubou é o da localidade. Estudos desenvolvidos por David Bohm e John Bell mostraram que partes de sistemas quânticos

... podem se distanciar muito, em possibilidade, uma das outras; mesmo assim, quando nós causamos um colapso numa parte, ao mensurá-la, a outra parte sofre um colapso instantaneamente, num estado que denuncia sua secreta correlação não-local. (Ibid., p. 49)

Mais surpreendente ainda foi a constatação de Bohr de que um elétron é uma onda quando é observado por um aparato de medição de ondas e não é uma onda quando observado por um aparato de medição de partículas. Ou seja, escolhemos a realidade de acordo com o modo como a encaramos, ela não é independente de nós. Com isso, questiona-se o princípio da objetividade e do epifenomenalismo, já que comprova-se que a consciência pode ter o poder de escolher a realidade material e, portanto, não pode ser apenas um epifenômeno da matéria. Indo adiante: se a consciência é não-material, nem todas as coisas fazem parte do domínio da matéria. Ou seja, cai por terra o último princípio, o do monismo materialista.

No entanto, é preciso fazer uma ressalva, pois paradigmas não vão para o lixo facilmente. Em sua Dissertação de Mestrado, "Tirando o manual do a utomático - do ma pa objetivo ao teritório transubjetivo nos caminhos do J omalismo", Patrícia Patrício afima que "uma nova visão de mundo não anula uma antiga, porém esta nunca mais será a mesma, pois que passará a ser examinada pela lente de uma outra visão de mundo." (p. 45)

Assim sendo, o que podemos deduzir para o jomalismo a partir desse passeio pela física quântica? Por que a quebra de muitos dos princípios da ciência clássica leva à corrosão dos pilares do jomalismo? Ora, porque, como já vimos, muitos 
a licerces do jomalismo têm estreita relação com a ciência clássica. Se antes acreditava-se que era possível deteminar com certeza o que era o mundo, agora já não se tem tanta certeza disso. E se nem a ciência possui mais certezas, por que elas existinam no jomalismo? Como saber se o que está na mídia é de fato a verdade? Aliás, será que existe apenasuma verdade?

Por outro lado, se a forma de efetuar a medição de um elétron já afeta seu comportamento, como sustentar que um jomalista seja objetivo ao realizar a captação dosfatosque irá relatar? Como garantir que ele não rea liza interferência alguma no próprio fato? Ah, e se nem todas as coisas fazem parte do mundo material, será que para relatar o mundo os jomalistas não deveriam também lidar com questões não materia is como as emoções?

São tantas as corrosões que podemos afimar estamos diante de uma verdadeira crise de paradigmas que atinge não apenas a ciência, mas também o jomalismo. “Mesmo não encontrando, literalmente, a expressão crise de paradigmas, podemos entender como crise esse momento de insegurança e de debate entre vá rias teorias científic as." (PATRÍc IO, 2002, p. 16)

Diante desse complexo cenário, o caminho mais plausível parece ser a realização de novas pesquisas e trabalhos no campo do jomalismo que passem a abarcar essas indagações e outras questões que, a té o momento, não tinham sido colocadas em pauta simplesmente porque pareciam já estar respondidas.

Qualquer que seja o cenário a ser enfrenta do pelo J omalismo, uma condição é subjacente: valores como objetividade e verdade precisam ser reavaliados. Não há como contomar o impasse. O J omalismo precisa enfrentar a discussão sobre sua relação como mediador social, repensando o que é um relato preciso, o que signific a reportar fatos com objetividade. Se o J omalismo se ocupa de certezas, e se as indagações acerca da participação da subjetividade emergem com força crescente, não mergulhar nesta busca pode comprometer ainda mais a função desse campo profissional. Se até mesmo os cientistas vêm mergulhando nestas escuras águas, por que jomalistas - que sempre se espelharam nos primeiros para definir método e conduta - inam se esgueirar? (C HRISTO FO LETT, 2004, p. 116) 


\section{De olho nas possibilidades}

Durante esse processo de busca pelas certezas, o jomalismo eliminou as dúvidas e tudo o que lembrasse a subjetividade de seu escopo de ação. Afinal, para garantir a correspondência entre fato e relato, muitos jomalistas a creditaram que a melhor altemativa era ser objetivo e imparcial. Em outras palavras, informar sem emoções, empregando citações diretas, citando fontes contraditórias, selecionando palavras que fossem o mais neutras possíveis, evitando o envolvimento com os acontec imentose as fontes, entre outros procedimentos.

O desejo de realismo no jomalismo, a obrigação que ele assume de daro real, levou à constituição de um sistema de técnic as que implica o uso de certos códigos, mantidos pela repetição. $O$ desejo de realismo impõe, desde a sua gênese, um jogo entre o falso e o verdadeiro. A verdade estaria nos fatos - no real concreto. Como o real concreto é aquele que se apresenta materialmente à nossa percepção, há uma deslegitimação do simbólico, que fala do impalpável. (BARROS, 2003, p. 86)

Como afima Ana Taís Martins Portanova Barros em sua Tese de Doutorado "Sob o nome de real: imaginários no jomalismo e no cotidiano", a busca pelo realismo levou o jomalismo a excluir de sua esfera de atenção tudo o que não estava materia Imente dado. Para Rogério Christofoletti, "por trás deste imperativo, está a idéia de que, se apresentada de maneira isenta e desapaixonada, a informação motiva o público a formar suas próprias opiniões" (p. 65). Assim, a objetividade seria uma tentativa de se criar um vínculo legítimo entre o jomalismo e o público. O autor relaciona outras funções subjacentes exercidas pela idéia de objetividade:

- por meio da objetividade os meios de comunicação estariam mascarando "o processo de construção social que pemitiria perceber a intemediação discursiva 
entre sujeito e realidade através da linguagem" (Sylvia Moretzsohn apud CHRISTOFOLETI, 2004, p. 83);

- convencer os leitores de "que se procura ser imparcial e objetivo, deixando a eles a escolha da afimação ma is verossímil, é um modo da empresa joma lística manter como seu público consumidor aqueles leitores que divergem da orientação editorial da public ação" (Alice Mitika Koshyia ma apud CHRISTOFO LETा, 2004, p. 88); - a objetividade também funciona como uma defesa para o jomalista contra críticas e questionamentos: "os jomalistas invocam a sua objectividade quase do mesmo modo que um camponês mediterrânico põe um colar de alhos à volta do pescoço para afastar os espíitos malignos" (Gaye Tuchman apud CHRISTOFOLETI, 2004, p. 90);

Pensando-se nessas funções e em outras mais exercidas pela idéia de objetividade, não é difíc il entender o porquê muitos joma listas são tão retic entes em aceitar a queda dessa noção e insistem em continuar a exercer a profissão da forma como sempre fizeram. Para esses jomalistas, romper a idéia de que é possível fazer um retra to fiel da realidade por meio de uma reportagem objetiva é destruir a própria essência do jomalismo.

Mas a questão é que, com o advento de descobertas que vêm abalando profundamente as raízes cartesianas que fundamentam o pensamento ocidental modemo, não podemos mais fechar nossos olhos e seguir adiante como se nada estivesse acontecendo. A boa notícia é que inúmeras pesquisas realizadas no âmbito do jomalismo e em outras esferas do conhecimento vêm abrindo novas portas para que possamos compreender o jomalismo sob uma nova perspectiva e, a os poucos, ir substituindo os a ntigos pila res corroíd os por bases ma is só lidas.

Essa nova maneira de enxergar o jomalismo o define como uma leitura possível da realidade. Nesse sentido, os produtos jomalísticos são leituras possíveis da realidade. Tratam-se de construções e não de reproduções ou retratos fiéis da realidade. "O jomalismo constrói realidades, sim, no mesmo momento em que é praticado, e isso independe do tipo de narativa: descamada ou literária, seca ou saborosa." (BARROS, 2003, p. 90) 
A reportagem, tal como um elétron, toma-se uma onda de possibilidade. E os jomalistas transformam-se em leitores do mundo, deixando de lado o penoso e pretensioso papel de ser alguém capaz de estampara verdade na mídia.

Essa mudança perspectiva é o primeiro passo para que o jomalismo desenvolva amplamente suas potencialidades. Ao reconhecer o jomalismo como uma forma de construção simbólica, reconhece-se também a existência de um sujeito construtor, de um mediador social. Isso representa uma grande oportunidade para que o jomalismo se liberte das amarras da objetividade. Afinal, quando se pensa o jomalismo como retrato fiel da realidade, todo o esforço é dingido para se esconder a existência do mediador.

É na costura do texto, na amarração das falas e descrições que se cria um efeito de objetividade, uma sensação de que os fatos falam por si mesmos. No funcionamento jomalístico, o profissional opera de uma forma que se apóia num apagamento de sujeito na rador. (CHRISTO FO LETI, 2004, p. 94)

Com a nova compreensão, todas as técnicas destina das a a pagar esse sujeito mediador tomam-se desnecessárias. Agora, o desafio é outro:

Não se trata de apresentar a realidade como ela é ao receptor, ambição objetivista, mas também não é o caso de assumir a própria subjetividade como detentora da verdade e impô-la aos outros, numa comupção do papel do autor. Pede-se ao jomalista humildade para assumir que não sabe tudo, e coragem para não se deixar tiranizar pelas exigências de objetividade que mais servem para encobrir contradições do processo de produção jomalístico do que a intenções de honestidade. Muito mais do que se manter frio diante dos fatos, a profissão de jomalista exige uma capacidade relacionadora para compreender um mundo que se apresenta complexo. (BARROS, 2003, p. 113)

Diante do grande desafio de fazer uma leitura do mundo que o considere em toda a sua complexidade, nada melhor do que contarmos com diversos aliados. É 
extremamente necessário e positivo fazer uma jomada ao encontro do que a história, a antropologia, a sociologia, a filosofia, a psicologia, enfim, as ciências humanas em geral podem trazer para contribuir com a renovação do jomalismo. Do contrário, corremos o risco de continuar a produzir um jomalismo reducionista, preso às velhas crenças deterministas.

Nós, jomalistas, esta mos demorando muito para oxigenar nossa menta lidade. A visão com que operamos ao pautar e desenvolver uma pauta tende quase sempre para o enquadramento esquemático do real, a atrofia de sua vitalidade enquanto processo. (MEDINA, 1991, p. 195-196)

A seguir, apresento pequenos exemplos de como o jomalismo teria muito a ganhar se passasse a olhar para outros campos do conhecimento em busca de respostas às suas próprias inquietações. Chamo de exemplos porque são apenas algumas conversas possíveis entre campos de saber, baseadas em um arcabouço restrito de leituras. São alguns fios soltos que, apesar de divididos em diferentes áreas do conhecimento, conversam entre si e podem ser costurados por outros pesquisadores adiante. Fios inspiradores para possíveis costuras futuras. Fios para tecer a lgumas idéias importantes antes do embarque.

\section{Um encontro com a histónia}

Conforme diz o historiador Georges Duby, em texto de outro histoniador, Jacques Le Goff (1984), a história só existe pelo discurso. E de acordo com o próprio Jacques Le Goff, um dos significados da palavra história é o de namação (1984, p.158), que pode ser um relato de fatos históricos (reais) ou somente de fatos imaginados (fábula). O jomalismo também existe pelo discurso e a narração é o que permite ao jomalista relatar o fato ou fatos objetos de sua matéria.

Os historia dores contemporâneos já assumiram que constroem, a partir de um fato, o fa to histórico. E que essas construções implic am reflexões teóricas, baseadas em hipóteses subjetivas, e empenho técnico. Por que então muitos jomalistas a inda 
se mostram tão temerosos em assumir que também constroem, a partir de um fato, o fato jomalístic o?

Talvez porque assumir essa construção signifique descer do pedestal de detentores da verdade e reconhecer o caráter de incompletude do jomalismo. Um caráter que só será reconhecido a partir do momento que o texto jomalístico conseguir transmitir tal preceito aos leitores. A partir do momento que o texto jomalístico deixar evidente que é produzido por um ser humano conseqüentemente imperfeito —, utilizando técnicas como a inserção de um narrador não onisciente no texto, abarcando emoções e impressões apreensíveis apenas a os olhos humanos etc. É assim que poderá haver uma verdadeira inclusão do humano no âmbito do jomalismo.

O historiador, ao assumir a postura de que constrói um saber que pemite ser chamado de científico sem, no entanto, dizer-se infalível, perfeito, indiscutível ou inocente, não feriu o valor científico da história. O jomalista, a o tomar uma postura de humildade, não acabará com sua legitimidade de mediador social. Pelo contrá rio, será a inda ma is legitimado ao se a presentar como um mediador-autor.

A história, ao reconhecer a construção simbólica e seus limites, ganhou a possibilidade de estar mais próxima do humano, de fazer o movimento individualcoletivo, particular-geral com mais desenvoltura. Com o jomalismo acontecerá algo similar, se empreender uma jomada tão profícua. Isso porque, a partir do reconhecimento de que é uma construção da realidade, o jomalismo deixa de enxergar tudo o que é imaterial como geme do não apreensível (tudo aquilo que não se entende e que não se pode explicar) — sendo preciso limpá-lo das histórias para que sejam perfeitas e permaneçam apenas no nível da abstração teónicocientífico. Ao compreender que é uma construção, o jomalismo poderá perceber que o ima terial, o tipic a mente humano e o partic ular são meios importantes para se chegar a geral, à quilo que é comum e compreensível à toda humanidade.

Assim, para construir sentidos mais gera is e completos, menos perenes e suscetíveis às mudanças de mentalidade que ocorrem a todo tempo, as novas orientações da histónia levam-na a ficar mais ligada à história vivida. As matérias 
jomalísticas, para deixarem de ser mera manchete esquecida quinze minutos depois do café da manhã, precisam buscar no humano, no concreto, matériaprima para sua construção. Incluir no seu diálogo mais do que os discursos das fontes oficia is e já consagradas.

O jomalista poderia agir como um historiador, que busca construir a legitimidade de sua leitura de mundo evidenciando quais discursos e documentos sua visão de mundo privilegia. Quanto mais transparentes formos em nossas construções, menos as matérias serão efêmeras.

\section{Um encontro com a antropologia}

Conforme definido pelo antropólogo argentino Néstor García Canclini, a cultura é "a produção de fenômenos que contribuem, mediante a representação ou reelaboração simbólica das estruturas materiais, para a compreensão, reprodução ou transformação do sistema social" (1983, p. 29). Se compreendemos a cultura dessa forma, podemos dizer que o jomalista é ta mbém um leitor-cultura l.

Está nas mãos desse leitor-cultural a opção de apenas administra ros sentidos vigentes ou tomar uma atitude para renová-los e reestruturá-los. No entanto, para decidir entre um desses caminhos, o jomalista precisa estar munido de ferramentas que the permitam compreender os conceitos cultura is. As teorias da cultura e uma visão compreensiva sobre a identidade cultural podem ajudar esse profissional a assumir de fato seu papel de leitor-cultural.

Além disso, o jomalista deve estar aberto para captar noções, emoções e comportamentos da sociedade em que está inserido. Para isso, precisa se sintonizar com a cultura de seu povo, percomendo o mundo com olhos de ver e não com olhos de constatar. Não basta ir à realidade colher o que já se espera e se sabe; a complexidade que nos rodeia exige um olhar de atenção especial capaz de acolher múltiplos sentidos.

Assim, um jomalista estará apto a decidir que caminho tomar (administrar, renovar ou reestruturar os sentidos) se estiver disposto a realizar um esforço de compreensão cultural da realidade. Se o objetivo for humanizar os sentidos 
produzidos pelo jomalismo, o caminho que se apresenta mais promissor é o de renovação e reestruturação dos sentidos cultura is. Seguir o caminho de administrar os sentidos vigentes é continuar a produzir, dentro do próprio jomalismo, as velhas fómulas do paradigma positivo-funcionalista, em que as complexidades do humano não têm lugarem palco.

\section{Um encontro com a mitologia}

Vejo a mitologia como um lago aberto de águas límpidas em que o jo malismo deveria beber muita s vezes. Se, como define J oseph Ca mpbell, mitologia são histórias so bre a sabedoria da vida, os mitos podem trazer sina is importantes aos jomalistas na confecção de suas matérias. Sinais que podem levar esses mediadores-autores a encontrar soluções mais eficientes para incorporar a experiência das ruas às narrativas, sem juízos de valor, mas com compreensão. Pois, o que leva as narrativas míticas a serem sempre atua is, é sua caracteństica de ser fruto da experiência e, por isso, elas têm sempre uma mensagem útil e aberta à interpretação do leitor.

Essas histórias mitológicas que, no fundo, de uma maneira bem particular e de acordo com a cultura de cada povo, acolhem um tema universal em seu interior, podem ser também uma boa fonte para aqueles jomalistas dispostos a se sintonizarem com o mundo. Ao lidar com a linguagem simbólica do mito, acredito que os jomalistas a cabam por se sensibilizar ma is perante a vida. J oseph Campbell define: "Mitos são pistas para as potenc ia lidades espintua is da vida." (1990, p. 32).

Escutar a melodia do mito implica, assim, escutar também a melodia do mundo. Para compreender um grupo social em sua profundidade, seria preciso também ouvir o som mitológico que esse grupo irradia. Ou seja, cabe ao jomalista, em sua posição de leitor-cultural, empenhar-se na identificação e na escuta dos mitos do seu povo e dos seus próprios mitos.

E este não é um trabalho em que o jomalista deve se esforçar apenas para identificar aqueles mitos que já se cristalizaram como dogmas, perdendo sua característica natural de imprecisão e ganhando contomos dramáticos. Trata-se de 
um esforço ta mbém na busca de ouvir os sons ma is submersos dessa sociedade, os quais não foram sequer enunciados.

\section{Um encontro com a sociologia}

No texto "A sociologia do Microssocial ao Macroplanetánio", Edgar Morin argumenta que, no novo paradigma da complexidade, conceitos como objetividade e subjetividade operam de maneira dialógica e não em oposição. Assim, ao pensar a impossibilidade de dissociar observador e observado, mas somente a possibilidade de distingui-los, a maior tarefa do sociológo contemporâneo consiste em se auto-relativizar, operar a auto-reflexividade e a autoc rítica.

Nesse sentido, a plena utilização da subjetividade - participação, curiosidade, interesse, afetividade, compreensão, enfim, a própria inclusão de si mesmo na narrativa - caminha em conjunto com a plena utilização da objetividade. O ma is racional aqui é o reconhecimento, por parte do sociólogo, do caráter ensaísta da sua própria produção.

Fazendo um paralelo com essas concepções, o jomalista, da mesma forma que o sociólogo, para construir uma narrativa complexa da realidade, precisa abandonar a posição desconfortável de que "diz a verdade objetivamente" e assumir o caráter de produção simbólic a relativa, colocando-se na narrativa como uma verdadeiro mediador-autor.

Não se trata aqui de propor a mudança de foco narrativo, como se uma primeira pessoa resolvesse a questão da inclusão do jomalista. A idéia é avançara discussão, estudando como seria possível construir um novo posicionamento durante a elaboração das matérias, desde a pauta, passando pela a puração das informações até a construção narrativa. Assim, o jomalismo poderia elaborar na rativas que levassem em conta as complexidades humanas da maneira mais abrangente possivel.

O argumento de que a questão da confiança e da veracidade ficaria abalada com a inserção de um posicionamento de autoria no jomalismo põe-se 
em cheque quando observamos que, na contemporaneidade, o próprio conceito de cientificidade é renovado: "Uma teoria não é científica porque é certa, mas porque se apóia em dados certos, ao passo que sua construção teórica é biodegradável (...)". (MORIN, 1998, p. 28)

Assim, nós, jomalistas, também precisamos encarar nossa produção simbólica como biodegradável e assumir a efemeridade de nossas interpretações e a permanência daquilo que menos se valoriza no jomalismo atualmente: as apurações acuradas, a capacidade de captar com compreensão tudo o que é próprio do humano. Iracional é permanecer a ver o mundo como uma dicotomia irrec onc iliável entre o subjetivo e o objetivo, excluindo-se e excluind o o outro.

\section{De olho na estrada}

Nesta estação de embarque chamada jomalismo, podemos nos deixar levar por várias estradas. Durante o meu percurso acadêmico pela graduação no Departamento de Jomalismo da Escola de Comunicações e Artes da USP, dois trabalhos universitários me marcaram: dois perfis, um sobre um porteiro e outro sobre uma secretária, elaborados para as disciplinas "Livro-reportagem l" e "Livroreportagem II", ministradas pelo professor Edvaldo Pereira Lima.

Conseqüentemente, optei por prosseguir nessa mesma estrada durante meu Trabalho de Conclusão de Curso, e construí a história de vida de uma ex-presidiária . Após o término da faculdade, continuei envolvida em contar histórias de pessoas, ao participar de um grupo de jomalistas criado, na época, pela doutoranda Andrea Pacetta de Amuda Botelho, para a realização de sua pesquisa de Doutorado. Esse grupo constituía-se de cinco jomalistas que participavam de oficinas de escrita. No final do processo, o objetivo era a produção de um perfil. Nesse caso, elaborei um texto sobre uma cobradora de ônibus.

Depois, ao entrar na pós-graduação, cursei a disciplina "Jomalismo Literário Avançado e Histónias de Vida: Uma Proposta Transdisciplinar", também ministrada 
pelo professor Edvaldo. Dessa vez, como trabalho final, apresentei o perfil de um doceiro.

Nessa rápida revisão de minha trajetónia acadêmica pelo jomalismo, fica nítida a opção de me deixar transportar pelas estradas do J omalismo Literário. Essa escolha não aconteceu por acaso. Encontrei nessa modalidade do jomalismo a mais ampla liberdade para construir minhas leituras de mundo, em uma tentativa de produzir textos de acordo com uma nova visão sobre jomalismo, inserida na crise de paradigmasa que me referi anteriomente.

Porisso, nada mais natural do que, nesta próxima viagem que percorreremos, continuar r trilhar essas mesmas estra das. Mas a final, que estradas são essas? Como elas surgiram? Por que encontrei maior liberdade por aqui? Quais são os pressupostos dos viajantes que a decidem seguir?

\section{Uma atitude, um modo de vere reportar}

De acordo com o professor Edvaldo Pereira Lima, “o Jomalismo Literánio é antes de tudo uma atitude, um modo de ver e reportar a realidade, independentemente do tipo de veículo que abriga a mensagem"1. Essa modalidade de prática jomalística começa a se desenhar a partir dos anos 1920 e 1930, quando a revista norte-americ ana "The New Yorker" passa a produzir um tipo específico de matéria jomalística chamado perfil. ${ }^{2}$

Até então, o que existiam eram iniciativas individuais em busca de produzir um jomalismo diferente do convencional. Nessas iniciativas, a principal inovação era o uso de recursos literários nas matérias jomalísticas. Foi daí que surgiu o nome J omalismo Literário. A inspiração vinha principalmente da escola do realismo social da literatura européia do século XIX, praticada por autores como Balzac e Charles Dickens, e da literatura norte-americana do século XX, cujos principais destaques foram J ohn dos Passose Emest Hemingway.

\footnotetext{
${ }^{1}$ LIMA, Edvaldo Pereira. Jomalismo Literánio no cinema. Portal TextoVivo - Na rrativas da Vida Real. Disponível em: www.textovivo.com.br. Acesso: 10/01/2005

2 LIMA, Edvaldo Pereira. Registros breves para uma história futura. Portal TextoVivo Narrativas da Vida Real. Disponível em: www.textovivo.com.br. Acesso: 25/09/2005
} 
Por volta de 1940 o J omalismo Literánio passa a ser reconhecido e praticado por um número considerável de jomalistas norte-americanos. Mas a nova modalidade vai se expandir pelo mundo e revolucionar as bases do jomalismo tradic ional nos anos de 1960 e 1970, quando surge o New J ouma lism.

... no começo dos anos 60 , uma curiosa idéia nova, quente o bastante para inflamar o ego, começou a se insinuar nos estreitos limites da statusfera das reportagens especiais. Tinha um ar de descoberta. Essa descoberta, de início modesta, na verdade, reverencial, podeńamos dizer, era que talvez fosse possível escrever joma lismo para ser... lido como um romance. (WOLFE, 2005, p. 19)

Segundo Tom Wolfe, nos primórdios do New J oumalism, o que os jomalistas desejavam era ter o privilégio de se vestir como os romancistas, os a rtistas literários dominantes daquela época. Não imaginavam o que estavam prestes a desencadear. Tom Wolfe chega a admitir que "não fazia a menor idéia de que essa histónia pudesse ter algum impacto no mundo literário ou em qualquer outra esfera, fora do pequeno mundo do jomalismo das reportagens especiais" (p. 41).

Mas os impactos foram grandes, espec ia Imente devido a:

- utilização de técnicas inovadoras de captação, como a imersão do repórter na realidade a sernarrada;

- emprego de recursos literários como diálogos, variedade de focos narrativos, a ltemância de pontos de vista e construção cena a cena, que pode ser definida como o "relato detalhado do acontecimento à medida que ele se desenvolve, desdobrando-se como em uma projeção cinematográfica."3

Diante das inovações, surgiram oposições tanto por parte de jomalistas quanto de literatos. De acordo com Tom Wolfe, muitos jomalistas não acreditavam na veracidade das cenas narradas, dos diálogos, enfim, achavam impossível captar o mundo com tantos detalhes. Já os literatos, até então tidos como os detentores exc lusivos da arte literária, sentiram-se ameaçados. 
No final da história, a pesar das o posições, o J oma lismo Literá rio consolid ou-se. No entanto, como a maioria das coisas no mundo, após um período de auge, vem a decadência. Com o passar dos anos, o New Joumalism foi perdendo a força naturalmente, não somente em decorência de críticas infundadas ou porque alguns jomalistas cometeram exageros estilístic os e reconstruíram personagens e situações de maneira duvidosa - claro que essas questões também influenciaram negativa mente -, mas especialmente porque toda a efervescência polític a e social que permitiu a ascensão dessa modalidade foi perdendo sua força. Dizendo de outro modo: os contextos mudaram e o Jomalismo Literário foi perdendo sua capacidade de renovação.

Não se deve deduzir equivocadamente, porém, que o Jomalismo Literário é exclusividade norte-americana. Aqui no Brasil tivemos um momento de apogeu de uma fase anterior, nos anos 1960 e 1970, com a magnífica epopéia da revista "Realidade" e com a menos glamorosa, mas igualmente importante produção do "Jomal da Tarde" paulista, que contou com grandes repórteres como Marcos Faerman, Femando Portela e Cláudio Bojunga. ${ }^{4}$

Assim como no Brasil, em diversos outros países latino-americanos houve produções memoráveis em Jomalismo Literário. O que ficou desse tempo de apogeu da modalida de é a certeza de que é possível fazer jomalismo sem fica mos presos à fómula do que, quem, como, onde, por quê. Ma is ainda: é possível fazer um jomalismo mais humano. Para Tom Wolfe, a partir do New Joumalism, passa-se também a pensarque a reportagem tem uma dimensão estética.

\section{Novos contextos, novos rumos}

Apesar da perda da força nos anos de 1960 a 1970, o Jomalismo Literário permaneceu vivo nos Estados Unidos. "A rigor, veículos de alcance nacional -

\footnotetext{
3 VILAS BO AS, Serg io. J oma listas-biógrafos: uma expressão de interc âmbios. Portal TextoVivo

- Narrativas da Vida Real. Disponível em: www.textovivo.com.br. Acesso: 14/08/2005
} 
como o 'New York Times', o 'The Washington Post' e o 'Los Angeles Times' - sempre mantiveram vivo algum grau de fidelidade ao Jomalismo Narrativo, mesmo nos cic los de 'baixa' dessa modalidade." 5

Aliás, nos Estados Unidos, Jomalismo Narrativo é um outro nome adotado para J oma lismo Literário. Há ta mbém quem chame essa modalidade joma lística de Literatura da Realidade, Literatura de Não-Ficção ou Creative Nonfiction.

O fato é que, recentemente, houve uma retomada do J omalismo Literário na imprensa norte-americana. Na busca por recuperar leitores, a mídia impressa voltou a apostar nas narrativas de fôlego. Em abril de 2001, resultados de uma pesquisa realizada por três instituições norte-americanas (American Society of Newspapers Editors, Newspaper Association of America e Readership Institute) mostraram que as na rativas realmente podem ser ferramentas importantes para atrair ma is leitores. Conforme relata Edvaldo Pereira Lima, a pesquisa evidenciou que "os jomais que incorporam o estilo narrativo em uma variedade de áreas temáticas são vistos como mais fáceis de ler."6

Em paralelo à essa retomada, podemos obsenvar alguns esforços na mídia brasileira em busca de textos mais arejados - merece destaque, nesse sentido, o trabalho desenvolvido pelo editor do Cademo Aliás, do jomal O Estado de S. Paulo, Fred Melo Paiva - e também o desenvolvimento de documentários com enfoque em histónias de anônimos - aqui podemos citar o trabalho de Eduardo Coutinho, Isa bel J a guaribe e J oão Moreira Salles.

No plano acadêmico, merece destaque o esforço de Edvaldo Pereira Lima no sentido de renovaras bases do J omalismo Literário no Brasil. Na evolução de sua carreira de docente e pesquisador na Escola de Comunicações e Artes da USP, após o doutorado, o professor se deparou com certas limitações do próprio

\footnotetext{
4 LIMA, Edva ld o Pereira. Registros breves para uma histónia futura. Portal TextoVivo Narrativas da Vida Real. Disponível em: www.textovivo.com.br. Acesso: 25/09/2005 5 LIMA, Edvaldo Pereira. Narrativa nos Jomais: A Experiência Americana (parte 2). Portal TextoVivo - Narrativas da Vida Real. Disponível em: www.textovivo.com.br. Acesso: $19 / 11 / 2005$
} 
Jomalismo Literário. Apesar da exuberância estilística dessa corrente e de sua aptidão para a captação cálida do real, encontrou um certo envelhecimento de sua visão de mundo. Os valores de fundo, os alicerces epistemológicos que sustenta vam o olhar do J oma lismo Literário não tinham acompanhado, na maioria dos casos, os extraordinários avanços de compreensão da realidade que as ciências de ponta haviam produzido.

Diante desse cenário, Edvaldo desenvolve um modelo diferenciado para o Jomalismo Literário, que denominou Jomalismo Literário Avançado. As bases conceituais da proposta vêm da física quântica e de muitas outras fontes tais como:

- Teoria dos Hemisférios Cerebrais: trata-se da “idéia universal de que tudo xpode ser compreendido como um sistema - conjunto de partes interdependentes a tuando de modo dinâmico." (LMA, 1998, p. 197)

- Teoria Gaia: de acordo com essa teoria, desenvolvida por James Lovelock e Lynn Margulis, "a Terra é um ser vivo, dotado de inteligência auto-reguladora que balanceia a atmosfera, os oceanos, o clima e a crosta terrestre em estado confortável para a manutenção da vida." (Ibid., p. 198)

- Teoria de Campos Morfogenéticos: baseada nos estudos de Rupert Sheldrake, sugere que "todo sistema é regido por um campo de memórias que se propagam por meio de um processo não material chamado ressonância mórfica." (Ibid., p. 197)

Com essas bases conceituais, o objetivo é que o Jomalismo Literário Avançado desperte uma nova consciência nos jomalistas. Em termos de técnicas de captação, a ênfase é nas entrevistas interativas, na observação participante e na identific ação de símbolos de status de vida.

Entende-se por entrevistas interativas, aquelas entrevistas em que acontece um diálogo possível, conceito desenvolvido pela professora Cremilda de Araújo Medina em seu livro “Entrevista. O diálogo possível." Segundo ela, o diálogo possível

${ }^{6}$ LMMA, Edvaldo Pereira. Narrativa nos Jomais: A Experiência Americana (parte 2). Portal TextoVivo - Narrativas da Vida Real. Disponível em: www.textovivo.com.br. Acesso: 
acontece quando entrevistado e entrevistador encontram-se e produzem um raro momento de humanização do contato interativo: "Tanto um como outro se modificaram, alguma coisa aconteceu que os perturbou, fez-se luz em certo conceito ou comportamento, elucidou-se deteminada autocompreensão ou compreensão do mundo" (MEDINA, 1990, p. 7).

Em termos de texto, usam-se as técnic as deriva das do new joumalism, com o intuito de equilibrar a eficiência informativa com a fluência na rativa. Para ajudar na a plicação dessa nova proposta, Edvaldo estimula a utilização de instrumentos como a Escrita Total, a J omada do Herói e as histórias de vida.

A Escrita Total é um método de produção de textos criativos, desenvolvido por Edvaldo Pereira Lima, que se utiliza de mapas mentais, visualização criativa e escrita rápida para proporcionar uma maior sensibilização dos jomalistas e para facilitar a elaboração da pauta, a realização das observações em campo e a própria produção dostextos.

A Jomada do Herói trata-se de uma proposta de estrutura namativa organizada pelo consultor de roteiro de cinema Christopher Vogler a partir de uma combinação de estudos mitológic os de J oseph Campbell e dos conhec imentos da psicologia de Carl Gustav Jung. Foi adaptada para utilização em jomalismo por Edvaldo.

Já a Histónia de Vida é um recurso de representação da realidade centrado na vida de uma pessoa ou de grupos. Nas ciências socia is, é compreendido como um método de pesquisa. No jomalismo, pode ser empregado como um suporte de pesquisa ou como principal veio narrativo. Em um contexto mais amplo, abrange biografias em um extremo e, em outro, perfis.

Quanto aoperfil trata-se de um...

...gênero que coloca em primeiro plano, preferencialmente, indivíduos e grupos socia is. No perfil busca-se construir retratos que a judem a compreender os valores, a visão de mundo, os traços de comportamento, as ações, as motivações que tomam 
cada ser humano único e ao mesmo tempo representante de uma partícula do vasto caleidoscópio narrativo que é a trajetória da humanidade na face da Terra. ${ }^{7}$

E foi elaborando perfis que passei a vislumbrar a importância de escrever histórias sobre as pessoas. Ao longo desse processo de profundo contato com os outros para a produção desses textos, comecei a perceber o quanto essa s relações me tocavam e o quanto deviam tocar essas pessoas que se dispunham a contar suas histórias para mim.

Por isso, nessa Dissertação de Mestrado, resolvi mergulhar em uma viagem mais ousada, para tentar identificar as possibilidades e limitações dessa relação que se estabelece entre o jomalista e a pessoa que se dispõem a contar suas memórias. Trata-se também de uma oportunidade para a abertura de um novo campo de estudos no jomalismo e talvez a chance de propor uma renovação do papel de jomalista na sociedade.

Pronto para a viagem? Então, seja bem-vindo!

7 LMA, Edva ldo Pereira. Jomalismo Literánio no cinema. Portal TextoVivo - Na rrativas da Vida Real. Disponível em: www.textovivo.com.br. Acesso: 10/01/2005 


\title{
Momento da partida: uma narrativa
}

\section{O homem que não pára}

\author{
“Penso que cumprir a vida seja simplesmente \\ compreendera marcha, e ir tocando em frente \\ como um velho boiadeiro levando a boiada, \\ eu vou tocando os dias pela longa estrada eu vou, \\ de estrada eu sou \\ Todo mundo ama um dia todo mundo chora, \\ Um dia a gente chega, no outro vai embora \\ Cada um de nós compõe a sua história, \\ e cada ser em si, carrega o dom de sercapaz, \\ e ser feliz" 8
}

As moléculas do ar começam a se agitar, os ruídos vão crescendo, a esca da do prédio de dois andares é tomada por um sobe e desce constante. Então, escuta-se uma gargalhada ou uma voz alta, levemente grave, falando com alguém de maneira veloz: podemos sentir as palavras correndo para se juntar a tempo de expressar os pensamentos que surgem por aquela boca em uma aparente desorganização caótica. As idéias passam a movimentar o ambiente com a mesma intensidade que ossons.

Estamos em uma das regiões ma is altas da cidade de São Paulo, em uma pequena travessa da rua Heitor Penteado, no prédio cinza da Editora Gente. Daqui de dentro, se prestamos atenção, há dias em que podemosouvir um carro de som lá fora, vendendo frutas frescas, e temos a gostosa sensação de que a metrópole ainda abriga alguns sabores do interior.

8 Da música “Tocando Em Frente", de Almir Sater. 
Mas todos os barulhos da rua parecem emudecer quando ele chega. É do primeiro andar, da sala branca de cortinas alaranjadas, que emana o agito. Ma is especificamente do homem de olhos levemente puxados, que aparenta 40 e poucos anos, mas tem 53. Dentro dele, há muitas explosões acontecendo, incômodos surg indo. É difícil manter tudo isso quieto, não é um processo do qual ele é dono. É como se algo viesse lá do fundo e passasse para o lado de fora espontaneamente, com a mesma intensidade com que nasceu.

Por isso, é impossível não notar quando ele chega: sua energia nos afeta, nos motiva a seguir adiante. Porque ele nunca pára. Ele é Roberto Shinya shiki.

\section{A cańcia essencial}

Os olhos se apertam. As marcas do tempo se evidenciam nas reentrâncias da pele próxima às pálpebras. Os dentes se mostram em um somiso, misto de a legria e tensão que toma conta dos lábios. Ele acabou de sair do camarim do Teatro das Artes, no Shopping Eldorado, em São Paulo. É 17 de novembro de 2005.

No palco, um telão passa e repassa uma mensagem para a platéia. O colorido das imagens se contrasta com o negro das cortinas que circundam o palco. Na lateral esquerda, escondido atrás das cortinas, ele observa a platéia, com seu somiso enigmático. Até que um assistente o interrompe:

—Dr. Roberto, o senhor pode passar a trás do telão e sair pelos fundos.

Ele faz um sinal negativo com a mão. Pede à Marisa, uma das secretárias da Editora, e a mim que prossigamos, saindo de fininho pela frente do palco. Como se isso bastasse para que ele se tomasse imperceptível.

Descemos os três lances de escada na frente dele, que repete o nosso gesto e pára por mais alguns segundos ali na frente, mantendo o mesmo somiso. Assiste com encanto à platéia. Para ele, o espetáculo já começou.

Há pouco tempo, diante daquelas mesmas cadeiras amarelas vazias, ele percomia o palco fazendo os últimos ajustes necessários, conferindo a apresentação em PowerPoint da palestra Heróis de Verdade, regulando a altura do 
som. Agora, as cadeiras estão tingidas com as vestes das pessoas que o esperam. Ele as observa com interesse e fascínio.

Já viu essa cena se repetir mais de 2 mil vezes, mas a sensação nunca vai embora: aquela vontade de que tudo dê certo. Adivinho que o desejo dele era permanecer ali por mais tempo. Mas em poucos segundos algumas pessoas se levantam para cumprimentá-lo. Então, ele se dinge para os fundos do teatro, onde chamará menosatenção.

Em breve, este mesmo homem sentará em um banquinho branco, diante do telão, para contar histórias do menino pobre de São Vicente, do adolescente roqueiro de Santos, do médico cirurgião, do psiquiatra, do terapeuta, do palestrante, do escritor, do pai, do marido... São muitos Robertos. Tão diferentes e tão igua is.

Todos eles viveram experiências únicas, atuando em lugares tão diversos como uma Unidade de Terapia Intensiva e um auditónio de uma empresa multinacional. Mas quando eles se unem no palco, só querem tocar os corações das pessoas. É um ímpeto de ajudar os outros, uma angústia diante do sofrimento humano, uma vontade neurótica de consertar o mundo. De acariciar.

Lembre-se de uma pessoa para quem você precisa dizer "eu te amo" ou "desculpe" e ligue para ela, agora, do celular!

Logo depois do pedido de Roberto, praticamente toda a platéia está falando ao telefone, muita gente tem lágnimas nos olhos. No entanto, essa capacidade de tocar as pessoas não se restringe aos momentos em que Roberto sobe no palco.

Durante o pouco tempo em que convivi com ele na Editora Gente - comecei a trabalhar com Roberto em agosto de 2005, ajudando a lapidar seus textos - fiquei surpresa com sua habilidade em despertar minhas reflexões, buscando me passar uma lição. Como o dia em que me disse:

Você não precisa dizer tantas vezes algo com que eu já concordei.

Um sinal de que confiava em mim, de que eu não precisava agir em defesa de meu teritório a todo o momento, com unhas e dentes, como sempre fiz. Ou 
então como daquela outra vez, em que ele me falou sobre a nossa característica comum de fazer as coisas com paixão e me alertou para o lado negativo de tanto entusiasmo, a perda de foco:

Às vezes dá vontade de dizer: manda essa mulher calar a boca, ela me enche a paciência contando detalhes do parafusinho!

Brincando, ele me deu uma lição importante, uma entre tantas outras. Carícias gratuitas, colocadas à disposição de quem está disposto a ouvi-las e a enca rar as próprias grandezase limites.

Frases assim não foram ouvidas apenas por mim. Elas marcam a vida e a memónia de quem convive com Roberto. Com Margaret Miraglia não foi diferente. Ela assessorou diretamente Roberto e comercializou suas palestras durante oito anos. Em 2005, passou a ser assistente de Operações e Recursos Humanos da Editora Gente. Morena, com seu jeito descontraído e brincalhão, ela disfarça sua timidez, que fica evidente na hora de falardas questões pessoais, quando o tom da voz toma-se mais baixo:

- Ele costuma falar que sou muito boazinha, que eu deveria mudar esse lado, ser ma is dura. Acho que antes eu passava muito a mão na cabeça das pessoas, a inda faço muito isso, mas melhorei bastante. Hoje me sinto mais dura, menos emocional, menos preocupada com a reação do outro e ma is preocupada em darum feedback para a pessoa para que ela cresça, por ma is que seja algo difícil de ser ouvido.

Meg sabe que nem sempre essas lições de Roberto vêm de uma maneira fácil, nem toda a carícia é um afago:

- Ele costuma falar que briga com quem acha que vale a pena, que vai crescer. Por mais que esteja dando uma dura na gente, chamando a nossa atenção, está tentando nos ensinar de a lgum jeito.

Um sentimento ambíguo toma conta de mim quando penso no modo como Roberto transmite ensinamentos. Às vezes, suas palavras são de uma dureza tão grande que não podemos evitar que as lágrimas invadam nosso olhos. Conviver com Roberto não é a lgo simples nem fácil. 
A imã de Roberto, Rosely Shinyashiki Boschini, atualmente uma das sócias da Editora, ta mbém coleciona em sua memória vários ensinamentos que recebeu do imão.

- Lembro que ele chegou assim, uma coisa até tonta, e disse: Rô, você tem a pema um pouco curta, já pensou que poderia usar um saltinho? Acho a té que eu não cheguei a usar imediatamente, mas a quilo fic ou na minha cabeça...

Hoje, os pés de Rosely vivem no alto. Mas não foram apenas eles que receberam a influência do imão.

- Quando eu tinha 17 anos, comecei a sentir uma dor de cabeça forte. Eu era muito apática, então o Beto chegou para os meus pais e disse: essa menina precisa de terapia!

O imão chegou até a a mumar um terapeuta para a imã. E não é que Rosely adorou a idéia! Começou a lidar melhor com suas questões e a desamarrar os nós que a prendiam.

- Meu pai preferia mil vezes que eu tivesse uma doença grave que justificasse minha dor de cabeça do que me ver toda a semana no terapeuta.

Com as descobertas rea lizadas com o a poio da terapia, Rosely resolveu fazer faculdade de arquitetura, naquele tempo, uma decisão incomum para mulheres. $\mathrm{E}$ prestou vestibular somente fora de Santos, onde morava com os pais. Foi um choque para o paie a mãe, mas ela seguiu adiante:

- Isso eu devo muito ao Roberto!

Ensinamentos assim Anderson Cerqueira Cavalcante também coleciona aos montes, em forma de inúmeras frases que ouviu a o longo dos 11 anos de convívio com Roberto. Uma dessas frases, que Roberto costuma repetir nas reuniões da Editora, é:

Você vai dar certo não porque é um gênio, mas porque os outros são muito ruins.

Ainda mantendo um jeito de menino, o mesmo de quando conheceu o médico, aos 16 anos, Anderson começou a trabalhar no Instituto Gente no início da carreira de palestrante de Roberto e atualmente é gerente geral da Editora Gente. 
Logo no início dessa parceria, Anderson cometia várias falhas, especialmente no momento de checar os itens essenciais para que os eventos promovidos por Roberto dessem certo. Sempre que alguma coisa dava errado, o garoto respondia:

- Pô, Roberto, mas eu risquei com o canetão esse item porque o cara falou que levaria lá.

Ao que Roberto respondia:

Não importa quantas vezes você passou o fax, nem quantas vezes você chutou para o gol, o importante é se a pessoa recebeu o faxe se você fezo gol!

Apesar de reconhecer que o chefe sempre foi muito exigente, Anderson admira a paciência que ele teve diante das inúmeras falhas cometidas pelo inexperiente garoto:

- Eu não sei se teria a mesma paciência.

Quando pergunto a Roberto sobre esse seu jeito natural de distribuir ensimanetose dicas, ele brinca dizendo que é exageradamente terapêutico.

Eu acho que às vezes não é legal para mim. Houve muitas pessoas que se aproveitaram disso. Muita gente se aproveita até hoje porque eu acabo sendo muito patema lista. Sou cha to, eu sei que cobro muito, mas perdôo muito os erros das pessoas. Eu fico acreditando no ser humano, estimulando ele a crescer... Isso deve me transformarem um cara muito chato, não é?

Olha, Roberto, já recebi muitas dicas em diversos ambientes de trabalho. Algumas técnicas, quase pontuais, sobre como fazer determinada tarefa de maneira mais eficiente; sacudidas que me balançaram depois que eu fiz uma grande besteira; elogios em que um chefe me dizia qua is caracteństicas eu não deveria perder ao longo da jomada. Mas nunca ganhei esses fios soltos que você me dá para que eu me costure melhor. Dá trabalho fazer remendos, talvez seja por isso que muita gente nunca se renove, mas lhe garanto que chato não é.

\section{O poder da solução}

As flores do campo, aos poucos, separaram-se do ramalhete com os gestos rápidos das mãos. Depois, foram unidas pela fita branca. Elas, que estavam ali 
apenas para enfeitar uma casa de Santos, transformaram-se para colorir o cabelo de uma mulher.

Aquelas mãos, dos imãos Rosely e Roberto Shinyashiki, nunca antes haviam passado pela experiência de lidar com flores, mas no dia 19 de dezembro de 1987, elasaprenderam ma is essa importante técnica da arte de viver.

- Quando descobri que o enfeite que eu tinha comprado em São Paulo não servia na minha cabeça e que as flores estavam murchas, foi aquela catástrofe! O meu vestido era muito simples, eu não podia gastar muito dinheiro. A única coisa engraçadinha era aquele enfeite. E em casa só tinha ficado eu e o Beto, porque ele é que ia entrar comigo na lgreja. Ainda bem que ele me falou: não se preocupe Rô, a gente pode improvisar. Foi engraçado porque ele me passou uma puta tranqüilidade. Mas acho que por dentro ele não estava tão tranqüilo assim... Imagina só a responsabilidade: levar a imã para o altar e aquela porra do detalhezinho dá errado! Justo com ele, que nunca foi de se preocupar com detalhezinhos. Mas nós conseguimos resolver a história no a to e eu garanto que fui a noiva mais linda que já teve!

$\mathrm{Na}$ volta do casamento, Roberto foi direto para o fogão, pois faltava preparar um creme de milho verde. Mas de onde vem o dom culinário do psiquiatra?

Quando eu era criança, minha mãe freqüentemente ia à farmácia, ajudar meu pai, então eu que fazia a comida. Ela deixava pronta, mas eu esquentava. Até hoje, sou um cara que me viro na cozinha tranqüilo. Em cinco minutos faço um almoço. Se, por exemplo, alguém me perguntar. Roberto, você faz o almoço para o pessoal da editora? Eu respondo que sim e faço em meia hora, invento ospratos e tudo. Porque eu que cozinhava e cuidava da tuma.

E que turma! Pela ordem de chegada: Gilberto, Roberto, Rosely e Eduardo. Entre Gilberto e Roberto, apenas dois anos de diferença. Rosely veio cinco anos depois de Roberto e Eduardo, um ano depois de Rosely. Mas nem sempre houve comida suficiente para todos na casa da família Shinyashiki. 
Aos quatro anos, eu me lembro de uma coisa muito forte, minha mãe falando para eu não comer mais porque meu pai não tinha comido ainda. Mas há uma outra cena que também me marcou muito, aos seis anos: minha mãe chegando com a sacola da feira. Ela vinha gritando da rua: vem me ajudar a carregar a sacola! E eu olhava aquela sacola imensa, cheia de frutas, de verduras...

Por estar entre os filhos mais velhos, Roberto viveu as fases mais difíc eis da família:

De quando nasci até completar um ano de idade, a gente morava de aluguel em um bairro simples, bem pobre de Santos. Tinha a sfalto, tinha bonde. Eu não me lembro disso, mas eu sei pela história. Quando eu comecei a andar, meus pais construíram um barraco na Vila Margarida, em São Vicente. Lá eles não pagavam aluguel.

Na Vila Margarida, o ônibus passava muito longe de onde a família morava. Roberto se lembra da quentura da febre e de sua mãe o carregando no colo, andando por quase uma hora com ele nos braços até chegar à rua por onde o ônibus passava para, só então, pegar a condução e ir a o hospital.

Masfoi o dinheiro economiza do durante a temporada na Vila Margarida, que durou de três a quatro anos, que possibilitou à família comprar uma casa na extremidade desse baimo pobre. Agora já estavam perto da rua em que os ônibus passavam.

Quando eu estava com sete anos, a gente foi morar na casa da minha avó patema, em Santos. Ela tinha um terreno que valorizou, então os filhos construíram casas dentro desse terreno. Foi o pior período da minha infância. Porque a família japonesa não aceitava o casamento do meu pai com minha mãe, uma brasileira. Só que minha mãe era uma mulher que saía na porrada com homem. Quando ela fic ava invocada, ela batia nos caras. Se ela tivesse aceitado a rejeição, não tinha dado encrenca, só que ela não aceitava. Então, quando alguém falava mal dela, ela já saía gritando: vai tomar no c..., sua fofoqueira! Era briga direto. Isso deve ter sido dos 7 aos 8 anos. Pelo menos quando a gente foi morar na minha avó 
estávamos em uma situação financeira mais legal, já tinha comida, já tinha coisa legal. Mas, assim, até os cinco anos foi muito pesado.

O pai da família Shinyashiki, seu Paulo, sempre trabalhou no ramo famacêutico. Desde que ficou órfão, aos 7 anos, foi lavar vidros em famácia. De empregado, passou a sócio e, depois, a proprietánio. Mas esse não foi um processo fácil e muito menos rápido. Por isso, enquanto seu Paulo lutava para conseguir sustentar a família, dona Benedita, a mãe, dava seus pulos para reforçar o orçamento da casa.

- Minha mãe trabalhava muito quando a gente era pequeno. Todo trabalho que ela podia realizar em casa, ela fazia: lavava roupa para fora, fazia saquinhos de chá para meu pai vender na famácia, pegava encomenda de defumadores de um centro espíita... Ela tinha um monte de ervas que a gente colocava para secarno sol e, depois que estava tudo sequinho, a gente separava uma certa quantidade: um pouquinho de malva, um pouquinho de alecrim etc. E minha mãe embalava e vendia para o centro espínta. Eu me lembro do Du pequeno vendo a gente ajudar minha mãe, sentado em cima de um cobertor, dentro de uma daquelas bacias de alumínio amassadas, que ela usava para lavar e quarar a roupa. Apesar de colocar a gente para trabalhar direto, era gostoso e tinha recompensa. Quando ela recebia um dinheininho, sempre fazia um doce.

Puxa, Rosely, deve ser daí que vem a loucura do Roberto por doces. Outro dia eu estava em reunião na minha sala, com uma outra jomalista, no segundo andar do prédio da Editora Gente e, de repente, ele passou pela porta e nos viu mastigando. Deu meia volta, retomou até o batente da porta e perguntou, já entrando na sala:

Édoce?

Eu confimei e ele, sem qualquer cerimônia, pegou uma paçoquinha "tipo caseira" do saquinho. Mordeu um pedaço e fechou os olhos, repetindo aquele típico e ancestral gesto que fazemos quando nosso paladar se regozija. Ofereci mais uma e ele, rapidamente, fugiu da sala, com o lamento de que precisa controlara bamiguinha. 
Mas essa não foi a única vez que peguei Roberto pela boca. Sempre que há alguma guloseima à disposição em um dos dois potinhos de vidro que ficam em cima de minha mesa e ele entra na sala, lá vão suas mãos ágeis beliscar um docinho. Um espontâneo e bem-vindo roubo...

Agora, voltemos à farmácia de seu Paulo que, apesar de sempre estar muito lotada, não era de dar muito lucro. Afinal, o pai de Roberto não tinha o dom de ganhar dinheiro. Ele era daqueles famacêuticos de antigamente, que gostavam de dispensar toda a atenção possível aos clientes, que conversava com as pessoas, que brincava com as crianças, mesmo que o balcão estivesse pegando fogo. Porque seu Paulo cuidava de gente e não de doenças.

- Sempre havia uma fila imensa para falar com meu pai e muita gente desistia de ir lá porque sabia que ia demorar. Quem tinha tino mesmo para negócio era minha mãe. Ela era essa figura que, quando atendia na famácia, sempre brincava: Ah, eu empurrei um monte de coisa! Então, se uma freguesa entrava para comprar um grampo de cabelo, ela dava um jeito da mulher sair de lá com laquê e mais um monte de coisa!

Se a família conseguia ganhar um pouco mais de dinheiro, dona Benedita não perdia tempo: comprava uma casa, reformava — com todos lá dentro, é claro - e vendia. Aí ela pegava o dinheiro e comprava uma outra casa que custava um pouco menos, assim, sobrava um pouco de dinheiro na mão e, aos poucos, eles puderam construir certo patrimônio.

Rosely acredita que, se dependesse do pai, talvez a família Shinyashiki nem tivesse se mudado para Santos, mas dona Benedita tinha uma espécie de "comichão": queria melhorar de vida. E Santos era uma cidade ma is urbanizada, com melhores colégiose ma is oportunidades...

\section{Os donos do futuro}

Os dedos começam a tocar as cordas da guitarra. Os fios obedecem aos movimentos certeiros e a música invade a noite. É quarta-feira, 21 de setembro d 2005 , mais de 22 horas. 
No pequeno palco, em Pinheiros, na capital paulistana, ele se solta e até ensaia alguns passos de dança. Debaixo do teto azul, o som do bom e velho rock and roll dos anos 60 trepida nossos corpos. Atrás da banda, as faces felizes dos Beatles contemplam o garoto, que continua a dedilhar sua guitarra. Agora, já não tem os cabelos longos, grandes são suas responsa bilida des.

Um livro novo está prestes a ser lançado, em breve se inicia mais um ciclo de palestras pelo Brasil, são cinco filhos para acompanhar nesta viagem, uma empresa e milhões de leitores. E ele está aqui, tocando para uma equipe de reportagem que faz uma matéria sobre pessoas que têm hobbies bastante diferentes de suas profissões originais. Uma frase palpita estridente como o som da guita ra:

Já que a gente veio até aqui, vamos nos divertir!

O ouvido capta a mensagem: a vida daquele homem continua a balançar com a mesma alegria e leveza daquele garoto que tocava no cais do porto de Santos, na banda Fire Emotion. Era um grupo de jovens que se juntavam sem ao menos ensaiar uma música e conquistavam a simpatia dos espectadores pouco convencionais da região. O cais se convertia em espaço cult nas madrugadas, onde se misturavam intelectuais, estudantes, marinheirose meretrizes.

Eu me sumpreendi ao ver aquele mesmo garoto aqui, no Dinossauro's Rock Bar, tocando com a tuma de cabelos brancos. O mesmo rapaz tímido e introvertido que praticamente se escondia atrás da guitarra, que fazia do rock and roll sua vida, continua a subir no palco. Um lugar que muitos dirão não ser apropriado para um médico psiquiatra e um palestrante requisitado. Mas ele não se importa com isso, sabe que, às vezes, precisamos contrariar as expectativas ou superá-las.

Afinal, com a guitarra na mão e ao lado da bateria, ele não precisa de ma is nada. Aqui, Roberto volta a ser o "China", o garoto de Santos. Aqui, os dois são um só. Um encontro perfeito, regado a cachaça de caju e a vibrantes melodias. Aqui, o menino vira homem e o homem vive o menino.

Eu vivi minha juventude nos anos 60, não era essa coisa que existe hoje, que eu chamo de realidades superpostas. Naquela época o mundo era preto ou branco. 
Com 14 anos, comecei a tocar em uma banda de rock. Quando tinha 15 anos, já estava em uma banda que tocava em bailes, festas e boates. E naquela época existiam dois tipos de banda: as certinhas, que tocavam igualzinho, e os caras que improvisavam. Eram apenas duas bandas em Santos que improvisavam, que tiravam som da guitarra, que tocavam Rolling Stones, J immy Hendrix, não sei o quê. Uma delas era a Fire Emotion. E eu estava lá!

Para Rosely, ter um imão que tocava em uma banda e que sempre trazia músic as novas para serem ouvidas em casa era o máximo.

- Ele era um ídolo para mim. Imagina, na era do rock and roll, eu tinha um immão que tocava! Mas nessa época eu via pouco o Roberto. Porque ou ele estava na escola, ou domindo, ou tocando ou na famácia, ajudando minha mãe.

Ah, eu também estudava violão clássico. Então, ficava com um violão ou com uma guitarra na mão pelo menos 14 horas por dia. Foi um peŕodo muito intenso da minha vida: música, música, música...

Resultado: a escola ficou de lado. A criança que se esforçava a o máximo para tirar as melhores notas da escola, que tinha orgulho de mostrar o boletim a os pais, tomou-se o pior aluno do colégio.

- O único motivo que fazia minha mãe brigar com o Beto era a escola. Ela também odiava aquela calça vermelha, aquele macacão laranja, aquele cabelão enome que ele usava, mas ela não se incomodava tanto com isso.

No entanto, Rosely lembra-se que seu Paulo não compreendia tão bem a situa ção, a chava que dona Benedita deveria ser mais enérgica com o filho, o que causava discussões entre o casal.

Minha mãe tinha um lance muito forte com artista. Então, quando ela ia a um baile em que eu tocava, ela fic ava nas nuvens! E meu pai... Era engraçado isso, ele se preocupava muito comigo, que eu só tocava, não estudava, mas tinha uma parte dele que parecia dizer assim: o Beto vai a rrebentar, uma hora ele acorda...

E ele acordou no dia em que o pai começou a chorare the confessou que não sabia mais o que fazer.

— Diz para mim como posso ajudarvocê? 
Foi aí que minha vida começou a se acertar, eu parei com as drogas.

Embora o envolvimento com as drogas não tenha sido pesado, ele chegou a utilizá-las nesse tempo de rebeldia. E acha que não mergulhou nessa praia porque quando estava tocando, já "viajava" natura Imente, sem a necessida de de nenhum facilita dor.

Na percepção de Roberto, não era a penas seu Paulo que, mesmo preocupado com as peripécias do garoto, a postava no futuro do menino. Lembra-se de quando foi parar na diretoria e de que o diretor da escola, professor Edízio del Santoro, disse que ele era inteligente e criativo, mas que isso não o autorizava a fazer bagunça. Depois de falar com Roberto, o diretor virou-se para a professora que reprovara o garoto e disse: você ainda vai ter muito orgulho de ter sido professora desse menino.

Hoje eu tenho certeza de que muita gente fala: puxa, fui professora dele!

Com o fim da fase da rebeldia, Roberto prestou vestibular e veio para São Paulo, junto com Gilberto, cursar faculdade. Os dois entraram em psicologia, Roberto na Faculdade São Marcos e Gilberto na Metodista. Como a situação econômica da família estava um pouco melhor, dona Benedita achou que valia a pena comprar uma casinha em São Paulo para que os dois morassem, em vez de pagar aluguel.

— Então minha mãe comprou uma casinha no "bico do corvo", bem simples, e começou a fazer aquele mesmo esquema de refomar e vender...

Mas, depois de alguns meses, Roberto voltou para casa em um final de semana e disse que não queria mais fazer psicologia, estava decidido a prestar medicina:

—Meu pai ficou só somiso!

Rosely conta que esse era o sonho do pai: ter um filho médico. Assim, Roberto voltou para Santose recomeçou a bata lha em cima dos livros para tentar passar no concomido vestibular.

- Essa coisa de estudar violão não é que ele teve professor não. Ele foi aprendendo na raça. Pegava a revistinha, estudava a posição das mãos, falava 
com as pessoas, ouvia dicas e ia embora... Então eu tinha certeza de que ele ia conseguir passar, mesmo que fosse difícil, porque o bicho sempre foi determinado.

Rosely estava na certa, na primeira tentativa, Roberto conseguiu!

\section{Sem medo de vencer}

“É noite. Uma pequena fogueira ilumina um grupo de 12 pessoas num sítio em Vargem Grande Paulista, a 1 hora de São Paulo. Ao lado delas, o desafio: um tapete de brasas de carvão se estende porcerca de 5 metros. O grupo se une num abraço, como um time de basquete antes da prorrogação. Depois eles se separam e, sob o comando do técnico, urram dando socospara baixo, três ou quatro vezes. Estão prontos. Estão em 'alta performance'. Então se perfilam descalços em frente dasbrasase, um por um, levantam a mão direita, batem a palma na palma de seu guru, dão mais um grito de guerra e passam decididos sobre o carvão pelando, a passos largos, olhando fixamente para frente. Do outro lado, outro grito, desta vez de comemoração. Essa cena, vivida no dia 30 de agosto do ano passado pela equipe da Compro Comunicação Promocional, é o ápice do seminário de Alta Performance de Roberto Shinya shiki..."

Este é o início da maior reportagem que já saiu na imprensa brasileira sobre Roberto, intitulada "O Guru". Publicada na revista Exame, em março de 1999, a matéria rendeu bons frutos, ajudando Meg a vender mais palestras.

- O Roberto sempre foi muito perfeccionista, quando eu entrei no Instituto Gente, ele estava fazendo o treinamento para lançar o seminário de Alta Performance. Durante dois meses, duas vezes por semana, ele chamava os amigos e dava o seminário nos fundos do prédio. Com os feedbacks, ele via o que precisava melhorar.

Anderson complementa Meg:

- Ele sempre foi exigente, sempre quis ser o melhor. Tem uma frase do Ayrton Senna que ele nunca me falou, mas eu sei que acredita muito nela: o barato da vida é quando você chega ao seu limite, e quando você chega ao seu limite, você descobre que, na verdade, ele fica um pouquinho acima. Se você analisar a 
carreira do Roberto, é muito isso: o melhor terapeuta, o melhor palestrante, o melhor autor etc.

Rosely explic a essa obstinação porfazer o melhor:

- Quando alguma coisa não dá certo, ele pensa assim: o que eu preciso fazer para comigirisso? E ele vai a onde for preciso ir para aprendero que deseja.

Quando entrei na faculdade de medicina, em Bragança Paulista, eu não tinha grana, por isso fui para a cinurgia, para ganhar dinheiro. Mas eu queria ser psiquiatra. Então, comecei a fazer psiquiatria clínica, desde o terceiro ano da faculdade, em um hospital em São Bemardo do Campo. Eu segui fazendo cirurgia e também estudando vários tipos de terapias... No segundo ano da faculdade, já comecei a estudar com um cara chamado José Ângelo Gaiarsa, que na época era um revolucionánio. No terceiro ou quarto, fui estudar com um outro cara chamado Roberto Freire, que era o 'the best'. Na mesma época, comecei a fazer cursos com Rolando Toro, criador da Biodanza. E também já me envolvi com a Análise Transacional, que era uma coisa que ia virarmoda tempos depois.

Ao teminar a faculdade, Roberto fez uma palestra em um Congresso Intemacional de Análise Transacional. Ao final do Congresso, houve uma votação para a escolha da melhor a presentação.

Foi o primeiro congresso em que eu me apresentei e ganhei o prêmio de melhor palestra! Então, no meu primeiro ano de formado, já saí para dar curso na América Latina sobre Análise Transacional.

Quando se formou, ele decidiu ir estudar nos Estados Unidos que, na época, era o melhor lugar para aprender terapias. Foi estudar com o criador da Gestalt, Fritz Perls. Quanto à Análise Transacional, fez cursos com as pessoas mais importantes da área, Mary McClure Goulding, Robert Goulding e MurielJ a mes.

Aí eu criei o Instituto Gente, no Brasil, e comecei a trazer para cá os melhores terapeutas do mundo para ensinaro pessoal a fazer terapia.

Estamos em janeiro de 1985 e Roberto decide escrever um livro que fale com simplic idade sobre conceitos da Aná lise Transacional. Quer criar um texto que seja compreensível não apenas a terapeutas. De posse dos originais, percorre durante 
um mês algumas editoras, mas todas dizem que precisam de tempo para estudaro material. Acontece que Roberto quer ter o livro pronto logo: em ma io irá presidir um Congresso sobre Análise Transacional e será fantástico poder distribuir exemplares durante o evento. Decide, então, fazer uma public ação independente.

É assim que surge a Editora Gente e o primeiro livro de Roberto, "A Carícia Essencial", hoje com ma is de 1 milhão e 600 mil exempla res vend idos no Brasil desde seu lançamento. Daí em diante, não parou ma is de escrever.

Buscando alcançar mais gente, em 1992 decide largar o consultório e passa a atender somente grupos e empresas.

- Lembro exatamente o momento que ele me falou assim: Rô, eu fico preso o tempo todo no 1 por 1 , fazendo terapia de pessoas que vão e voltam com os mesmos problemas e, quando eu faço uma terapia mais forte, a pessoa fica com receio porque, muitas vezes, não quer mudar.

Ao partir para os grupos, Roberto presenciou uma crescente demanda por participação. A sede do sítio de Itapecerica da Serra, especialmente desenvolvido pela arquiteta Rosely para acomodar as pessoas durante os workshops e as maratonas tera pêuticas, não dava conta de tanta gente.

Mas a insatisfação de Roberto voltou a se manifestar. Nesse meio tempo, ele foi se aproximando cada vez ma is do universo comorativo. A partir de 1986, devido às inúmeras solicitações que recebia de diversas companhias, passou a estudar administração de empresas: foi ao Japão e, depois, cursou um MBA executivo na Faculdade de Economia e Administração da USP. Assim, começa sua carreira como palestrante.

- O Roberto a rrebentou porque, antes dele, as palestras eram como aulas, não existia essa possibilida de das pessoas se solta rem, a brirem o coração, chorar.

É assim que Anderson conta como Roberto reinventou a arte de palestrar, ainda no tempo em que era um terapeuta renomado e liderava o Instituto Gente, o centro terapêutico que funcionava na mesma pequena travessa da rua Heitor Penteado, no prédio cinza em que hoje está a Editora Gente. Ministros e famosos faziam terapia com ele. 
- Era uma época em que praticamente não existia um carro como o Audi nasruas, mas a gente via Audi parado todo dia na frente do Instituto.

Foi ali que Anderson começou a trabalhar com Roberto.

- Minha mãe era empregada da imã da Isla, gerente geral do Instituto Gente. Lá, eles estavam precisando de uma pessoa para digitar uma lista de 200 a 300 pessoas, convidadas para participar da festa de comemoração dos dez anos de lançamento do primeiro livro do Roberto, "A Carícia Essencial". Então eu fiquei em uma salinha catando milho, demorei dois dias para fazer um serviço que se faz em duashoras.

Para ajudar o garoto, que vinha de uma família simples e já tinha sido feirante, ajudante de pedreiro e entregador de mala direta, Isla the amumou uma vaga de office-boy no Instituto. Anderson começou a trabalharem 28 de agosto de 1995, no dia 1 de setembro foi registrado.

Em poucas semanas de trabalho, ele já abria o prédio do Instituto. Como fazia faculdade e tinha de sair às $17 \mathrm{~h} 30$, chegava ao local às 8 horas.

- Eu fazia os pagamentos nos bancos, era auxiliar de escritório e também ficava na recepção. Rapidamente comecei a trabalhar na área administrativa financeira. A Isla fazia essa parte, mas não tinha saco para isso. Seis meses depois, eu já era auxiliar administrativo financeiro.

Mesmo com a demanda muito maior do que a procura e com todo esse movimento em busca de trazer os melhores terapeutas do mundo para darcursos no Instituto, as finanças não iam bem. Em 1996, um consultor do Sebrae a nalisou a situação e chegou à conclusão de que a forma como o Instituto trabalhava invia bilizava o lucro.

- Os tera peutas cobravam de 2 a 3 mil dólares, dez anos atrás, para dar um curso de um final de semana.

Mas os custos não paravam por aí, havia passagens de primeira classe, pois, nomalmente, os terapeutas exigiam dois bilhetes, sem contar hospedagem, a limentação etc. 
Como os cursos já não eram baratos, a única solução seria abrir mais vagas, masnão havia a possibilidade de fazer tamanha expansão.

Quanto às sessões de terapia conduzidas por Roberto, eram rentáveis, mas signific avam muito pouco se comparado às palestras.

- Por exemplo, se uma consulta custava $\mathrm{R} \$ 2$ mil, em uma palestra ele ganhava pelo menos dez vezes mais.

Além disso, nas palestras, Roberto conseguia alcançar um público muito maior do que em seu trabalho como terapeuta, desenvolvido durante sessões, workshops e maratonas. Assim, durante todo o ano de 1996, ele conciliou as duas profissões: fez palestras pelo Brasil e continuou investindo recursos no deficitário Instituto.

Então, no final daquele ano, Roberto convidou Anderson para almoçar em um restaurante popular por quilo, pertinho da Editora, chamado Mia, que continua funcionando no mesmo lugar até hoje.

- Lembro que foi engraçado porque eu paguei o almoço! Não foi bem um almoço, foi mais uma entrevista. Ele disse que o consultor do Sebrae tinha falado muito bem de mim e que tinha tomado uma decisão: fechar o Instituto e ficar só comigo e com a Isla. E foi assim que começou nossa história, nosso pacto. Ele queria alguém que pudesse ser formado por ele para que, depois, essa pessoa o acompanhasse nas palestras. Ele falou para mim: é de você que eu preciso nessa minha nova carreira de palestrante!

Para Rosely, aquilo era uma loucura total, parartudo e fazer só palestras:

- Uma coisa é você dar terapia para um grupo de 60 pessoas, outra coisa é você ter uma hora com as pessoase fazer elas saírem transformadas.

Era como se ele se jogasse no vazio, um salto no abismo, fazer rapel sem a corda de segurança! E a frase que Rosely ouviu da boca do imão, naquele momento, ela não esquece:

Rosely, se eu não abandonar o velho, o novo não entra.

- Aí eu senti a inquietude do Roberto, ele é incapaz de fazer a mesma coisa se ele não vê que está provocando algo de bom naspessoas. 
Assim, em 1997, o homem que não pára inicia sua carreira solo como palestrante. Acompanhando Roberto por mais de oito anos durante suas apresentações pelo Brasil, Meg adorava ver as reações das pessoas:

- É uma coisa fora do comum. É ruim fazer essa comparação, mas sabe Igreja? Então, o pessoal fica daquele jeito, hipnotizado. Naquele momento, se ele falarpara todo mundo se jogarda janela, todo mundo se joga.

Masquem pensa que até hoje Roberto atua nesses palcos, engana-se...

\section{O sucesso é ser feliz}

As mãos nos botões, os pés sonhando com a bola:

- Pai, eu consegui chegarna final!

O grito é de André, um garotinho meio tímido, meio radical, de 8 anos, filho de Roberto e Cláudia Bava Shinya shiki. André está no andar de baixo da cobertura da família, em São Paulo, jogando videogame. Eu e Roberto estamos no andar de cima, lendo a penúltima versão do texto de Heróis de Verdade, livro mais recente do autor, lançado no final de 2005.

É outubro, deve ser ma is de 21 horas.

Aqui em cima, depois de subir as escadas, do lado esquerdo, há uma pequena cozinha, adiante um banheiro cuja porta é um grande espelho e, depois, o escritório de Roberto, todo branco, onde uma guitarra divide espaço com o computador e os livros da estante. À direita, uma ampla sala em que está a mesa sobre a qual estamos relendo o texto do livro e a porta que leva à piscina e à churrasqueira.

Depois de escutar o chamado do filho, Roberto responde:

- Tô trabalhando, me chama quando começaro segundo tempo.

Depois dos 45 minutos do primeiro tempo - que devem durar cerca de 15 minutos no "tempo" do videogame - André volta a chamar:

- Pai, vai começar!

Roberto então desce as escadas e eu continuo a leitura. Impossível não notar aquela cena tão simbólica. Imediatamente penso nos trechos do livro em que o 
narrador discorre sobre a importância de ser um pai de verdade, de estar ao lado dos filhos nos momentos que são especia is para uma criança - como a final de um campeonato de futebol no videogame.

- G0000000000000!!!!

Escuto os dois comemorando a cada conquista de André! Por último, a voz do pai:

\section{_Parabéns, filho!}

Minutos depois, Roberto sobe as escadas e retoma o trabalho.

Mas o campo de futebol não se vê apenas na tela do videogame. Às vezes, a própria sala em que estávamos lendo se transforma em gramado para as partidas de André e Roberto. Eles também adoram bater uma bolinha na praia, enquanto Cláudia toma sol e Marina, a caçula, de 5 anos, faz construções na a reia na companhia de a lguma a miguinha.

André gosta tanto de futebol que treina no Clube Pequeninos do Jockey. Trata-se de uma associação de futebol infanto-juvenil, fundada em 1970, que funciona na chácara do Jockey Clube. Famoso por conquistar muitos títulos e formar craques, o clube só cobra mensalidade de quem pode pagar, por isso atende a muitas crianças carentes. Assim, o local acaba promovendo a mistura de meninos fãs de futebol de todasas classes sociais da cidade.

Roberto sente-se feliz pelo filho ter a oportunidade de conviver em um grupo tão heterogêneo, afinal, é preciso aprender a lidar com a realidade dura do mundo desde cedo. Um dia, Roberto disse que André veio reclamar com o pai porque alguns garotos disseram que iam "quebrar" ele no jogo. Então, o pai disse:

Pois é filho, ou eles notam você ou nem se lembram que você existe. O que você prefere?

Ele conta isso enquanto saboreia a came assada pelo amigo Álvaro, advogado, que comanda a churrasqueira na casa de praia alugada por Roberto em J uquehy, São Sebastião, litoral norte de São Paulo. Álvaro e sua esposa são pa is de dois garotos que têm a mesma idade de André e Marina, todos estudam no mesmo colégio. 
A casa é um simples sobrado mobiliado que fica dentro de um condomínio fechado pertinho da praia. São três quartos, do is banheiros, sala de estar, cozinha e copa. Além da came assada, temos espetinhos de queijo, salada de alface e tomate, farofa e arroz. Com exceção do churrasco, tudo foi preparado pelas mãos de Luciana, a empregada que acompanha a família há um ano.

Conheci Luciana logo que entrei na Editora Gente, em uma palestra de Roberto para cerca de 220 funcionários da Dicico, uma loja de materiais de construções. O evento aconteceu no Centro de Convenções Pompéia, dia 23 de agosto de 2005. Ele levou Luciana para assistir à palestra e pediu para o pessoal da Editora ficar junto com ela até que o evento teminasse, pois então ele a levaria de volta para casa. Lembro-me de que, durante a palestra, ele mencionou o nome de Luciana para dar um exemplo sobre como a ensinara a fazer os sucos do jeito que ele apreciava.

Aliás, essa palestra na Dicico só aconteceu porque o dono da empresa é amigo de Roberto. Afinal, 2005 foi o ano em que o palestrante decidiu parar um pouco com aspalestras...

— Em novembro de 2004 ele foi à Índia e me ligou de lá falando que ia parar com as palestras em 2005. Por mais que eu percebesse que ele não ia ma is com tanta empolgação para os eventos, não acreditei que ele fosse parar. Até que em dezembro ele voltou para o Brasil e me disse que não faria o menor sentido eu continuar no Instituto, já que não teníamos muito trabalho. Só aí eu acreditei e, então, passei a trabalharna Editora.

A notícia que surpreendeu Meg não causou o mesmo espanto em Rosely, acostumada às constantes mudanças do imão.

- Apesar do absurdo financeiro que ele enfrentou por parar com as palestras, era algo que ele precisava fazer para continuar a respirar. Sabe aquela inquietude que ele teve lá atrás, quando começou a dar as palestras? É a mesma coisa. 
Rosely também menciona o doutorado que Roberto cursa atualmente na Faculdade de Economia e Administração da USP como uma das razões da decisão:

- Para se dedicar de verdade ao doutorado, ele precisava abandonar as palestras. Se não fizesse o doutorado direito, ele não seria o mesmo. Não ia conseguir se olhar no espelho.

A inquietação de Roberto chegou a Anderson no formato de duas perguntas, no final de 2004:

Você acha que eu tenho que me aposentar porque estou bem e sou respeitado? Ou preciso me reinventar e continuar a minha ca reira?

Anderson nem precisou pensar na resposta, imediatamente disse:

— Pelo amor de Deus! Você a posentado ninguém a güenta! Pa rado não dá!

Então, 2005 foi mais um ano de virada na vida de Roberto. Um ano em que ele se dedicou "apenas" ao doutorado, ao livro Heróis de Verdade e às palestras de lançamento do novo livro.

Essa mudança de rota gerou uma grande transformação no cotidiano de Cláudia e das crianças. Afinal, houve meses em que Roberto chegou a dar 32 palestras, três em um mesmo dia. Passava mais tempo longe do que perto da família, morava mais dentro do avião do que em casa.

- Daí que a gente vivia que nem namorado de novo, embora a gente já fosse uma família, porque ele viajava tanto que, quando chegava, dava sempre uma saudade, aquela sede de se encontrar. De alguma maneira esse era o lado bom dessa história.

Uma história que durou do nascimento de André, que chegou dois anos depois do casamento dos pais, até 2004, quando Roberto fez mais uma de suas viagens à Índia. Que seria ma is uma viagem entre tantas se não fosse pelo tsunami. Ao ficar sabendo da tragédia, Roberto decidiu tentar ajudar as vítimas e acabou acompanhando de perto o sofrimento de muitas famílias. Será que a decisão de parar com as palestras em 2005 foi influencia da pela viagem à Índia? 
- O tsunami foi uma experiência muito forte para ele. Mas eu acho que ele parou com as palestras porque já não tinha aquela coisa apaixonada, não fazia mais com aquele encantamento. Mas eu não acho que a decisão venha fácil. Principalmente nesse negócio, com todo o reconhecimento, com todos os pedidos... É difícil decidir parar com algo que está dando certo. Acho que ele foi decidindo por etapas, até que uma hora não teve jeito. Esses sinais - como o tsunami e outros a contec imentos - reforç aram um processo intemo já existente.

A resposta da terapeuta Cláudia diz muito sobre Roberto: ele é movido à paixão. Tanto que sempre diz que somos parecidos nesse ponto: fazemos as coisas com paixão, com intensidade.

— Ele é extremamente intenso em tudo: quando é na alegria, é na alegria, quando é na tristeza, é na tristeza, quando é na angústia, é na angústia... No amor, na paixão é assim. Tudo o que ele faz, ele faz muito intensamente. Então eu acho que não dá para fazer a vida inteira. Tem uma hora que torra. Grupos de terapia: ele passava meses, às vezes direto, emendando um workshop no outro. Uma hora você não agüenta mais ver cliente, ouvir gente falar e reclamar! Entende? Esse é muito um movimento dele. Então, se ele dá palestra, ele dá palestra até esgotar! Aí ele não quer mais...

Como nada na vida de Roberto é uma decisão definitiva - ele é capaz de mudar de idéia a cada movimento do músculo cardíaco - em 2006 ele quer retomar sua atividade de palestrante. O que não significa recomeçar a dar palestras do modo como fazia antes. O que ele quer agora é revolucionar, é fazer algo diferente a cada nova subida aos palcos, a cada nova saraivada de palmas, esse estrondoso barulho que tanto o atrai.

Mas será que se dedicar muito a uma coisa, esgotá-la e revolucionar é mesmo uma característic a comum de Roberto?

Eu preciso estar feliz. Entre tocar no Dinossauros e fazer o doutorado, eu faço os dois com intensidade. Para mim, serfelizé não ter que fazer escolhas. E é besteira lutar contra o meu ritmo. Por isso que eu acho muito legal ter essa habilidade de escritor. Sempre que a grana a perta, eu vou para o livro. 


\section{Pais e filhos, companheiros de viagem}

O livro tem uma vida própria, ele vai se revelando aos poucos, é que nem filho. E a gente tem que aceitar e respeitar um filho como ele é, e não como a gente queria que ele fosse...

Pais e filhos: relações complexas, ensinos e a prendizagens que vêm e vão. $\mathrm{O}$ pior e os melhores momentos da vida de Roberto estão relacionados às histórias vividas com seus filhos.

O pior dia foi a sexta-feira em que eu recebi a notícia de que precisava levar o Leandro a um neurologista.

Quando pedi a ele para me contar melhor essa história, ele disse para eu procurá-la em dois de seus livros, "O Poder da Solução" e "Pais e filhos, companheiros de viagem". Nos dois livros, ele conta o drama que viveu ao descobrir o problema de Leandro. Então, nada mais apropriado do que as próprias palavras de Roberto:

Um dia, recebi um telefonema avisando que o pediatra tinha solicita do uma a va lia ção neurológica do menino, porque havia sido constatado um atraso no seu desenvolvimento. O diagnóstico neurológico foi a traso médio neuropsic omuscular. Essa notícia me ating iu como um soco no peito e me chamou à rea lidade.

Começou, então, a via-crúcis: fisioterapia, terapia ocupacional, fonoaudiologia, hidroterapia - era preciso recuperaro atraso no desenvolvimento.

Ao mesmo tempo, ele foi submetido a uma série de consultas a diferentes especialistas na tentativa de diagnosticar a causa do problema. A princípio, as hipóteses eram muitas, tantas quantas os pais (eu e a mãe somos médicos) conseguiam formular. (...)

Infelizmente, os tratamentos não produziram os resultados desejados, e o sentimento de impotência foi tomando conta de nós. Por fim, uma tomografia fechou o diagnóstico: sua doença era causada por uma série de calcificações no cérebro, conseqüência de uma virose durante a gestação. 
Vánios médicos nos disseram: "Infelizmente, ele não chegará até 1 ano de idade". Até hoje não encontro palavras para descrever a dor que sentíamos naqueles primeiros meses cada vez que olhávamos nosso menino e pensávamos que em breve não o teríamos ma is conosco.

Não queńamos que ele morresse no prazo previsto pelos médicos. Redobramos, então, nossos esforços recorrendo a homeopatia, a massagens e a energização - tudo o que se possa imaginar.

Ele foi ficando mais forte. Aos poucos aumentava a certeza de que ele iria viver pelo menos alguns anos a mais do que fora previsto.

Então, com sua situação estabilizada, começaram os questionamentos. Por que isso havia acontecido justamente comigo? Eu, que sempre tinha sido um homem bom, que não sentia nenhum prazer em fazer mal a os outros!

Sentia um misto de ressentimento e frustração contra a Existência, que, segundo meu modo de ver, havia me preparado uma cilada. Entrei em depressão profunda: junto ao sentimento de que nada tinha valor na vida, expenimentava a sensação de impotência e incapacidade. Parecia não ser capaz de fazer nada certo.

Alguns meses depois, viajei para os Estados Unidos em busca de algo que me tirasse daquela permanente angústia e participei de uma série de grupos tera pêutic os residencia is.

À medida que fazia as terapias, fui descobrindo pontos que me ajudaram a esclarecer o que estava vivendo. Lembro-me especialmente de uma sessão em que falei de minha dor por ter um filho com uma doença neurológica. A terapeuta disse que sentia muito, mas que essa era uma situação real, e o que eu tinha a fazer era aceitá-la e aprender a viver com ela. Mostrou-me que a terapia lida com o ima ginário e que eu deveria ver se não existiria algo nesse aspecto para trabalhar.

Percebi então minha dific uldade de ac eitar um filho naquelas condições. $\mathrm{Na}$ evolução da sessão, tomei consciência de que, mais ainda, eu não sabia aceitaras pessoas como elassão. 
Dias depo is soprava um vento muito forte. Eu caminhava em sentido contrário ao dele, procurando avançar, e não conseguia. Tentei várias vezes. Subitamente constatei que era exatamente isso que fazia em relação ao meu filho. Lutava contra a situação, estava magoado poralgo que não saíra como havia planejado. Percebi que, assim como o vento, a vida não soprava naquela direção por estar contra mim. Simplesmente existiam fatores na natureza que a levaram a tomar determinada direção naquele dado momento.

As coisas desagradáveis não aconteciam contra mim, ac ontec iam comigo, e eu não iria resolver a situação lutando contra elas. A doença de meu filho não era conseqüência de um ato errado que eu tivesse cometido nem se tratava de uma punição. Era somente uma situação que me estimulava a crescer.

Era o momento de aceitar que ele, como todos os filhos, possuía caracteństicas próprias. O seu jeito peculiar de ser não tinha como finalidade me fazer sofrer - era, simplesmente, seu jeito de existir.

A partir daí fiz tudo para começar a conhecê-lo em vez de querer mudá-lo. Até hoje, com 22 anos, ele faz uma série de atividades pedagógicas especiais e, em certos momentos, sinto o desejo de que as coisas fossem diferentes, mas logo depois voltamos a nos entender.

Nós, pais, temos de aprender a aceitar nossos filhos e seus caminhos. Se quisermos, sempre encontra remos algo em nossos filhos que nos deixa rá insa tiffeitos.

Não tenho dúvida de que, dando-me esse filho, a Existência encontrou uma maneira de me transmitir ensinamentos profundos sobre a vida.

Ao vê-lo tão feliz no seu jeito de ser...

Aprendo a vera beleza do simples.

Aprendo a me comunicar sem palavras.

Aprendo a valorizar o pequeno:

cada pequeno gesto,

cada pequena evolução.

Pequenoscaminhos.

Aprendo a olhar meus sentimentos, 
mesmo aqueles menos admiráveis,

e a considerá-los parte de mim.

Especialmente, aprendo a aceitar que não sou tão grande como imagino e gostaria de sere que devo serpaciente para aceitar minhas limitações. ${ }^{9}$

E o melhor momento Roberto?

Puxa, eu tive muitos melhores dias, mas eu acho que foram os nascimentos dosmeus filhos.

Roberto acompanhou os cinco partos. E diz que foi obrigado a aprender a ganhar dinheiro depois do nascimento de Leandro, quando buscou incessantemente proporcionar a o filho o acesso às melhores terapias.

Agora isso também tem a ver com uma neurose minha porque os pais da Lúcia (mãe de Leandro) eram muito ricos e, se eu tivesse sido mais humilde, não precisaria ter feito tantas loucuras...

E ele fez todas as loucuras que um estudante de medicina podia fazer para ganhar dinheiro: estágios de manhã, à tarde e à noite além de, durante várias madrugadas, elaborar traba lhos para os colegas de curso. Anderson explica:

- Os judeus têm um ditado interessante sobre isso: vêm os filhos, vem o dinheiro. Foi por causa das condições que Roberto proporcionou ao Leandro que hoje ele é capaz de andar, ir direto à tomeira, pegar água, beber. Antes ele não fazia nada disso. Ele é um milagre da medicina. E eu tenho certeza de que, se o Roberto pudesse fazer alguma coisa hoje, realizar um sonho, ele faria o Lê se sentir melhor, ma is feliz e ma is a mado.

Depois de Leandro, filho do casamento de Roberto com Lúcia, médica pediatra, foi a vez de chegar Ricardo e Arthur, filhos do casamento de Roberto com Ana Maria, terapeuta. Por último, vieram André e Marina, filhos do casamento com Cláudia. São tantos filhos, que ele sempre brinca com Cláudia:

Você me escolheu porque você queria ter filhos lindos, porque você já sabia como iam ser os meus filhos! 
— Sem sombra de dúvida, esse é o papel em que ele é ma is feliz. Quando ele está com o André e com a Marina, ele vira criança também! Às vezes ele tem que aprender a parar, porque ele não é um garotinho e se deixar fica jogando futebol, jogando futebol... Mas ele é um ótimo pai. Não é aquele pai do dia-a-dia, que busca na escola, na natação. Ele não faz isso. Até que este ano ele fez mais. Masa estrutura para essas coisas precisa existir independentemente dele, porque a gente nunca sabe quando ele não vai estar. Então, as crianças não contam com ele, não esperam o pai ir buscar. Masquando ele vai, é uma festa.

Cláudia também admira a habilidade de Roberto para lidar com as peculiaridades de cada filho. Se percebe que está mais distante de um deles, ele vai lá e se aproxima daquele filho.

- Eu acho que os filhos mais velhos confiam muito nele. Embora sejam adolescentes e, é claro, briguem com ele. Mas ele é muito maduro até mesmo para ouvir as crític as e enfrentar as brigas.

Mas será que a relação que Roberto está vivendo com André e Marina é muito mais próxima do que a que ele construiu com os outros filhos?

— Não, é diferente. Porque eu acho que ele foi mais pai do dia-a-dia com os outros, durante a infância primeira deles, do que foi com os meus. Na época em que o André e a Marina nasceram, ele já estava dando muita pa lestra. Equando os outros eram pequenos, ele estava separado, então ele tinha todo um investimento no dia-a-dia dosfilhos, buscava na escola, jantava junto todas as noites em que era possível. Ele nunca se distanciou dos meninos. Claro que não tinha o acordar e o domir junto de todo dia, e eu acho que isso fez muita falta para ele e foi por isso que ele sofreu muito.

O vazio deixado pelas crianças ficava marcado na sala de jantar solitária. Anos depois da separação de Ana Maria, Roberto ainda sentia uma dor ao se deparar com a mesa abandonada. Quando estava namorando Cláudia e pediu sua ajuda para decorarum apartamento que havia alugado, disse que não queria sala de jantar. A solução foi encontrada por um arquiteto de Salvador, que

\footnotetext{
${ }_{9}$ Texto public ado no livro "Pa is e filhos, companheiros de viagem", p. 78-81.
} 
transformou o que seria um ambiente triste em uma espécie de sala de jogos, com lustre baixo e poltronas que se encaixavam embaixo da mesa redonda.

- O Roberto não viu os três primeiros filhos crescerem, uma vez ele me falou uma frase que me marcou muito: Anderson, a pior dor do mundo é você chegarà casa da sua ex-mulher, tocar a campanhia, a porta se abrir, e você observar seu filho dando aqueles dois, três passinhos de costas para você.

Ao perguntar para o Roberto se, a pesarda separação, ele conseguiu manter sua relação com os filhos inabalável, ele solta direto uma exclamação:

Ah, não tem jeito! Eu acho que eu sou um cara super presente, mesmo o Ric (Ricardo) e o Tuk (Arthur), que são maiores, eu procuro acompanhar. Mas não é a mesma coisa. Agora que estou podendo ter a expeniência de dormir e acordar com o André e a Marina, vejo que é muito diferente.

Mas parece que essa diferença na relação com os filhos é resultado também de uma outra mudança:

- Eu vejo que hoje, com o André e a Marina, ele é um pai muito mais presente: viaja mais junto com eles, brinca mais. Ás vezes eu ligo às 10 horas da manhã, em uma segunda-feira, e ele está jogando bola com o André. Antes, isso nem passava pela cabeça dele porque a agenda inviabilizava essa possibilidade.

$\mathrm{Na}$ opinião de Anderson, essa busca de Roberto por estar mais próximo da família e dos amigos tem sido ma is intensa nos últimos dois anos, tempo em que começou a aprender a curtir a vida. Aliás, para Anderson, esse é um dos principa is pontos fracos de Roberto:

- Ele aprendeu a dar o sangue, a ser o melhor, a ser o homem da casa, a trabalhar, a fazer dinheiro, a educar os filhos e se esquec eu de curtir a vida.

E note que Anderson tem autoridade para falar sobre o assunto. Nesses onze anos de convívio com Roberto, eles construíram uma relação de cumplicidade e respeito. Para Meg, que acompanhou de perto a trajetória dos dois, eles são como paie filho.

- Lá atrás, a gente teve uma vida parecida, então fomos nos identificando bastante. Mastudo começou porcausa da intuição e do faro dele. 
Filho de pai pemambucano e mãe baiana, que vieram para São Paulo naquele esquema em que a mala é um saco e o cadeado um nó, Anderson também viu a pobreza de perto na infância. Até os sete anos, morou no bairro que era tido como o mais violento de São Paulo naquele tempo, o J ardim Miriam.

- Quase todo dia, quando a gente chegava em casa, tinha um morto na calçada.

Quando almoçou pela primeira vez com Roberto, naquela conversa em que ele comunicou que ia fechar o Instituto, Anderson se lembra de que Roberto fez diversas perguntas para compreender um pouco da história daquele garoto. Até então eles mantinham uma relação mais distante, Roberto conhecia pouco sobre a família de Anderson.

- Na época, eu não tinha noção do quanto era importante minha história, do quanto meus pais me ensinaram valores funda menta is.

Valores que permitiram a Anderson agir de maneira diferente da maioria das pessoas, que costumam dizer amém a tudo o que Roberto fala. Mas Anderson nunca teve receio de discordar.

- Teve o caso de uma empresa que queria contratá-lo para fazer 10 palestras e ele não queria dar nenhum desconto. Então eu falei: tá bom, Roberto, você não dá nenhum desconto e a gente corre o nisco de perder esse negócio, mas me explica qualé a sua lógica para que eu possa aprender.

Na hora, Roberto reconheceu a destreza de Anderson:

Só por causa dessa pergunta todo mundo aqui vai ganhar um salário de prêmio!

É por essa s e outras histórias que, hoje, Anderson sente-se à vontade para dar alguns puxões de orelha em Roberto.

- Uma vez ele comprou um temo de uma marca boa, cara, e chegou na palestra com aquele temo e com um sapato americano, desses que duram 15 anos e parecem de fábrica. Eu fui falarpara ele que não combinava, e ele sempre tinha um argumento, dizia que era confortável, coisa e tal! 
Isso quando ele não colocava a calça jeans com o sapato marrom, a camisa verde e o cinto azul claro! E as gravatas vinho? Para essas também não faltavam explic ações:

É que vinho é a cor do sangue de Cristo, representa a compaixão, abre o coração das pessoas para o que você está falando...

Anderson simplesmente respondia:

— Ok, isso é legal, mas de vez em quando você pode rezar antes da palestra e pôruma gravata azul, né?

Roberto é tão desligado dessas questões materiais que só adquiriu um apartamento próprio há cerca de nove anos, quando decidiu se casar com Cláudia.

Eu moro em um puta apartamento, mas seu eu tivesse que morar em um sitiozinho, ia ser igual para mim. Eu sou arrogante pelo que sou e não pelo que tenho. E sou simples por causa de tudo o que já fiz, o que me dá uma tranqüilidade de dizer assim: se precisar voltar a dar palestras, eu volto; se precisar voltar a trabalhar com terapia, eu volto... Este ano eu vivi com $10 \%$ do que vivi no ano passado, sem problemas. O que eu acho legal é que as pessoas com quem eu convivo ta mbém não ligam para isso.

Mas tem muita gente que liga, né, Roberto. Como diz Anderson, não tem jeito, o mundo é capitalista.

- O ito anos a trás ele já tinha dinheiro, mas andava com um Versa illes ca indo aospedaços. Para ele comprar um carro novo, o Mondeo, foi uma briga! Tudo bem que ele é simples, mas um cara que está pagando $\mathrm{R} \$ 20$ mil em uma palestra não espera que o cara venha de Versailles. Não precisa comprar uma Ferrari, mas de Versailles não dá!

Engana-se quem pensa que os toques de Anderson se restringem à esfera das aparências.

- Quando eu falo que a gente discutiu e brigou muito, me refiro ao trabalho e também à personalidade. Da mesma forma que, se ele me detonava, eu 
entendia que era para o meu bem; se eu fazia o mesmo, ele também compreendia que era para o bem dele.

Anderson se lembra do dia em que Roberto resolveu chamar a atenção de um funcionário na recepção. Ele a rrasou com o rapaz na frente de todo mundo. Então Anderson esperou ele teminar e o chamou para a sala de reuniões:

- Você nunca mais faz isso com ninguém a qui na empresa!

Contando a história, Anderson se recordou que Roberto fez isso outra vez dias atrás.

— Isso é errado por definição e o Roberto fazer isso é a inda pior!

Outra atitude de Roberto que incomoda bastante Anderson é a dificuldade em pedir a opinião dosoutros.

- Ele chega para você e fala assim: faz assim e assado, tá bom? Repete para eu ver se você entendeu. Não sei se ele já fez isso com você, mas é como se ele chamasse a pessoa de imbecil!

Anderson a lertou Roberto para o quanto esse tipo de atitude inibe as pessoas de darem idéias e crescerem.

- Pode ver que, agora, nas reuniões, ele está tentando ouvir mais o que as pessoas pensam, pergunta o que elas acham, se elas têm algo a agregar.

Está buscando lidarmelhor com o lado impaciente do Roberto empresário.

\section{Você: a alma do negócio}

Domingo, 17 horas, o telefone toca na casa dos pais de Anderson. Era Roberto:

Vem para a minha casa agora que eu quero falarcom você!

Uma cena bastante similar aconteceu comigo no dia 18 de dezembro de 2005, também no fim da tarde de domingo. Roberto ligou no meu celular e perguntou:

Podemos conversaragora? Seria um bom momento...

Eu estava em casa e me amumei o mais depressa que pude para me encontrar com ele no Fran's Café, na praça Benedito Calixto, 191. Afinal, apesar 
de, nos últimos dois meses, agenda mos diversas entrevistas durante o horánio de expediente, sempre acontecia algum a traso nas reuniões marcadas anteriomente ou algum imprevisto e ele desmarcava a entrevista.

Claro que, de vez em quando, Roberto entrava na minha sala, abria um de meus potinhos de guloseimas e disparava a falar sobre sua vida. Ou então soltava frases e histórias durante nossas reuniões e depois falava:

Acho que isso já pode ajudarvocê no perfil...

Agora, voltemos à casa de Roberto, Anderson já chegou.

— Anderson, o pessoal da Editora respeita você?

— Eu acho que sim, porque eu nunca precisei usar seu nome para conseguir nada ali dentro.

- Estou com alguns problemas e gostaria que você se tomasse o gerente geral da Editora, só que é o seguinte: eu vou dar algumas metas pra você cumprir até o final do ano e, se você não cumprir, eu vou ter que dispensar você. Você topa?

— Eu topo!

Anderson estava com 21 anos e era conhecido como o braço direito e esquerdo de Roberto, por isso, não podia se a miscar, não dar certo, e retroceder. Era junho de 2000 e ele teve apenas um mês para trabalhar de perto com Roberto, trocar idéias e aprender o máximo possível, pois Roberto estava se preparando para deixar o país a caminho de Sydney, na Austrália, onde enfrentaria o desafio de cuidar do equilíbrio emocional da delegação brasileira nas Olimpíadas. $\mathrm{Na}$ volta, acabou levando a culpa pelo país não ter conquistado uma única medalha de ouro. Meg quase enlouqueceu, pois antes da viagem, Roberto estava muito confiante e disse, em algumas apresentações, que se não voltasse com certo número de medalhas de ouro, baixava o cachê.

- Você não imagina a loucura que foi, a notícias se espalhou e as pessoas ligavam para saber o que ia acontecer. Foi difícil lidar com isso mas a gente não baixou o cachê porque, se tivesse feito isso, seria o fim! 
Em entrevista à revista Istoé, em 18 de outubro de 2000, Roberto avaliou sua partic ipação nas O limpíadas:

Não ganhei um centavo para acompanhar a delegação brasileira. E fiquei muito sa tiffeito com o resultado. Eu estou feliz porque os atletas que me procuraram estão felizes. Femado Scherer, por exemplo, torceu o tomozelo 20 dias antes das Olimpíadas. Os médicos e o próprio técnico não acreditavam na possibilidade de ele competir. Ele estava superbaixo-astral. Me ligava toda a noite. Fizemos vários exercícios de mentalização e relaxamento. Mesmo sem ter o treinamento adequado, ele competiu e acabou ajudando o revezamento a ganhar medalha. Por isso eu digo que o meu traba lho foi um sucesso. Um amigo me perguntou como era viver com a imagem a rranhada. Eu prefiro uma imagem arranhada do que uma consciência a rranhada. Se não crucificassem os atletas, iniam me crucificar. Há momentos em que é ma is fácil falar que o técnico ou os atletas falharam. Mas não falharam.

Demorou mais de um ano para que as pessoas e a imprensa deixassem Sidney para trás... E enquanto Roberto enfrentava os desafios e conseqüências das Olimpíadas, Anderson enfrentava uma bata lha não menos difícil no Brasil.

Quando Anderson foi para a Editora, sua experiência administrativa se restringia ao Instituto Gente que, desde aquele tempo, era responsável por cuidar da carreira de Roberto e contava somente com quatro funcionários: uma secretária, Meg, Anderson e Benício - motorista de Roberto. Já na Editora havia 42 funcionários e toda uma rotina de trabalho completamente desconhecida por Anderson.

— Foi aí que a prendi, não a administrar, masa liderarpessoas.

No final de novembro, pouco antes de seu casamento - que aconteceu em 2 de dezembro - Anderson já tinha conseguido bater $90 \%$ de todas as metas estipuladas por Roberto.

Apesar de sempre ter ocupado o cargo de presidente da Editora, Roberto nunca tinha colocado a mão na massa, até 2000 , quem tocava tudo era Rosely. 
Assim, quando Anderson assumiu a gestão da Editora, iniciou-se um processo de aprendizado conjunto.

- Ele teve que começar a olhar balancete, uma coisa que ele nunca tinha feito antes. Nesse sentido, ele mudou muito, porque, a té então, o Roberto não tinha cabeça de empresánio, mas de terapeuta. E terapeuta é assim: planta a semente dele, se der, deu, se não der, tudo bem. Empresário não! Se não der, ele tem que vender o patrimônio dele na semana seguinte.

Durante esse processo de aprendizado, Roberto passou a ouvir mais as pessoas, para poder conhecer melhor um negócio que não era de sua total competência.

- O senso de urgência dele passou a ser muito mais aguçado.

Com todas essas transfoma ções, Roberto passou a ser ma is objetivo. Durante as reuniões, ia direto ao ponto, algo que não fazia quando era a penas tera peuta e palestrante. No entanto, isso também aumentou sua impaciência:

- A cabeça dele é como se estivesse em uma rotação adiantada. Então muita coisa ele já viu ou já sabe o caminho. Por isso ele passou a não ter ma is a mesma paciência de quando ele era terapeuta.

\section{Mistérios do coração}

Ele era uma coisa estranha em todos os sentidos, desde o jeito que se vestia até a forma de falar. Ele já era uma lenda para mim. Eu estava fazendo um curso de formação em análise transacional no Instituto Gente há um mês e ainda não o conhecia, as aulas eram ministradas por um assistente, pois ele tinha viajado à Índia.

Para mim foi um espanto completo: alguém que vai para a Índia e visita mestres? Eu achava que isso era uma história do passado, que só existia em livros de andarilhos. Meu mundo era assim: o próximo carro que você vai comprar, quanto custa pagar a faculdade. Então, naquele momento, eu acho que não cheguei a ver o homem. Eu vi apenas uma coisa totalmente diferente de mim. E fiquei extremamente fascinada com tudo aquilo. 
Praticamente todas as pessoas que estudavam comigo conheciam ele de alguma forma e contavam que ele usava bigode, mas ele voltou da Índia sem bigode. E chegou supercabeludo. Eu não lembro da roupa dele nesse primeiro dia, mas me lembro de outros dias em que ele usava coisas como uma jardineira e um chinelo. Nessa época, ele era muito desencanado. Ele fazia esse gênero... Não, acho que ele não fazia gênero, ele era assim. E como já tinha uma certa posição, podia se darao luxo de fazer o que bem quisesse. Como psiquiatra ele já era muito importante, embora eu nunca tivesse lido nada sobre ele nem ouvido falar dele no meio acadêmico que eu freqüentava, que era o curso de psicologia da PUC. Para mim, ele era um absoluto estranho, mas eu sabia que ele tinha uma importância dentro daquele meio em que eu estava acabando de entrar.

$\mathrm{Na}$ verdade, no dia em que chegou, ele não deu uma aula, ele foi contara Índia, o que ele fez e aprendeu por lá. Então, para mim, era um susto aquilo tudo porque eu não conhecia esse mundo, eu vinha de uma coisa extremamente contida e certinha. Já estava fazendo um enome esforço de fazer aquilo que eu estava fazendo: um curso, à noite, em um lugar que não era uma escola. Era tudo muito surreal. Para mim aquilo não entrava em nenhum dos meus mundos conhecidos.

Nessa época eu era praticamente casada, não era casada porque não tinha nem idade para isso, estava com 19 anos. Mas eu já namorava um cara há uns cinco anos. E era uma relação bem fechada, bem certinha. Vivia aquela vidinha regrada de namoradinho certinho. Todo dia tudo igual, uma verdadeira rotina. Então ir ao curso e quebrar essa rotina era uma coisa muito difícil pra mim, era abrir uma porta para o mundo, um risco.

E aí a minha vida mudou radicalmente depois do Instituto Gente. Ali eu descobri tudo: que eu poderia atender de verdade, que eu seria uma profissional de verdade, que não existia só a psicanálise... Enfim, o mundo se abriu completamente a partir desse momento. Ali eu comecei a me tomar Cláudia Bava Shinya shiki... 


\section{Amar pode dar certo}

— Foi tudo muito rápido, quando eu me formei, em 1990, já era esta giánia do Instituto Gente e tinha feito todas as formações que você pode imaginar. Nessa altura do campeonato, eu não tinha ma is namorado porque trabalhava todos os fina is de semana, todas as noites, inintemuptamente e, ainda por cima, fazia faculdade. Além disso, minha vida tinha mudado completamente e minha cabeça junto. Foi uma revolução completa, em todos os sentidos: valores, estrutura, visão... Então, como presente de formatura, eu pedi a meu pai que me desse uma viagem à Índia.

Era a primeira vez que Roberto ia guiar um grupo de pessoas a o místico país. Havia cinco terapeutas estagiários no Instituto e três deles embarcaram na idéia: Cláudia, Luiz Antônio e Marli.

- Nessa época, meu foco era todo esse: acertar com os pacientes, ser a melhor assistente, fazer tudo certo para nunca levarbronca.

Mas não a diantava, por mais que se esforçasse, era inevitável que a garota de 22 anos tropeçasse de vez em quando. Se levava uma bronca, reagia de maneira passional, saía chorando, pois qualquer crítica de Roberto abria feridas morta is.

- Embora me magoasse profundamente, eu agradecia muito as broncas dele, porque era algo que contribuía muito para a minha formação.

Foi preciso ir à Índia para descobrir que não era exatamente a bronca do chefe ou do professor que tanto a incomodavam, mas o homem que havia atrás de todos aqueles papéis.

- No Instituto, eu era assistente, supervisionanda, fazia alguns grupos terapêuticos, partic ipava como cliente em a lgumas maratonas etc. Uma confusão! Só quando eu fui para a índia que comecei a olhar para ele, porque aí a gente passou a ter uma convivência menos dentro dos papéis. Com essa convivência, comecei a percebê-lo e notei que aquele monte de sentimentos que eu tinha e que me incomodavam significava uma única coisa: eu estava apaixonada por ele. 
$\mathrm{Na}$ Índia, todos os dias, às 17 horas, havia um encontro com Osho, líder espintual indiano, em que ele dava uma benção em todos. Um ritual extremamente importante, pessoas esperavam horas na fila para poder acompanhar de perto a benção. Era o momento em que todos colocavam a túnica branca, enquanto que, durante os demais momentos do dia, usava-se uma túnica bordô.

Mas como uma das principais caractenísticas dos a paixona dos é romper com as regras estabelecidas, Roberto sugeriu que Cláudia e ele fossem jantar naquele dia e faltassem à benção. Sentindo um pouco de remorso, eles fugiram para o encontro em que revelaram os sentimentos que nutriam um pelo outro. $O$ beijo selou o início daquela primeira noite de amor.

No dia seguinte, ao voltarem para o convívio dos discípulos de Osho, surpreenderam-se com o clima do local. Durante o café da manhã, reinava um silêncio absoluto, uma introspecção incomum.

- Demorou algumas horas até a gente descobrir o que tinha acontecido durante a benção do dia anterior: eles informaram que Osho tinha desencamado. Foi uma coisa muito forte, pois começamos a namorar exatamente no dia em que Osho morreu: 19 de janeiro de 1990.

Como os outros do is assistentes eram a migos bastante próximos do casal, foi tranqüilo comunicar a novidade. Já haviam algumas fofocas rolando entre os estagiánios.

— Olha o jeito que ele olha para você, Cláudia! Ele se separou...

—E eu dizia: ima gina, o cara não está nem aí!

Ele era 15 anos mais velho do que Cláudia e, na cabeça da garota, ele a achava uma "garotinha imbecil e meio insignificante". Na volta para o Brasil, a filha de descendentes italianos ficou sem coragem de contar sobre o namoro a seus pais, demorou cerca de uma mês para se abrir.

- Quando eu falei que estava namorando ele, minha mãe teve um ataque, fic ou muito brava. Achou que eu estava com alguém que ia me trocar por uma de 20 anos quando eu fizesse 40. Ela tinha posições muito rígidas a respeito dele já ter passado por dois casamentos, ter três filhos. Já meu pai não ficou muito bravo, ele 
se preocupou com o significado daquilo, espantou-se um pouco e escondeu-se atrás da minha mãe, quietinho...

Seguiu-se o namoro, que foi muito difícil para Cláudia, porque aquele relacionamento era totalmente contra o que sua família queria. Ela brigava quase todos os dias em casa, saía e não podia nem dizeraonde ia.

- Minha mãe me falava que eu usava a minha casa de hotel, porque eu chegava lá para domir. E realmente era verdade. Mas toda a minha relação com o Roberto acontecia no trabalho mesmo, eu não precisava de mais. A gente ficava junto um ou outro final de semana, nessa época ele também ficava com os filhos então às vezes eu ficava junto, às vezes não. Mas a gente ia para tanta maratona junto, para tanto workshop, em tudo quanto é lugar, que nem precisávamos de mais nada. Aí em 1992, eu consegui morar sozinha, não agüentava ma is aquela pressão.

Na mesma época em que saiu da casa dos pais, Cláudia também foi embora do Instituto Gente. O grupo de estagiários do qual ela fazia parte queria ganhar mais, aumentar o percentual que recebia pelos trabalhos realizados, mas o Instituto não aceitou a reivindicação. Isso gerou um desgaste muito grande e Roberto decidiu que não queria mais aquele bando de gente lá.

-A gente foi a primeira geração de expulsos, depois tiveram outros...

Cláudia ri quando se lembra disso.

— Mas de novo eu agradeço profundamente o Roberto. Porque, embora eu tenha me sentido expulsa e a namorada tenha ficado enlouquecida, porque sofria pelos amigos e por ela própria, por outro lado, se eu tivesse ficado ali, do jeito que eu funciono, provavelmente permaneceria ali a vida inteira. Para mim teria sido muito difíc il ir embora por conta própria, eu era muito identifica da com ele e com o trabalho dele. Em a lguns grupos tera pêutic os que eu coordenava, falavam que eu parecia com ele, até fisicamente, porque você vai incorporando a voz, o tom e tudo mais. Em um trabalho muito emocional isso faz diferença. Então eu tinha um jeito dele de terapeuta, tinha fama de serbrava, de serdura, de ser uma terapeuta 
confrontativa. Por isso, foi fundamental ter saído do Instituto, senão provavelmente eu não teria feito carreira solo, teria sido etemamente uma sombra.

Qualquer outra mulher ia ficar perto de mim para pegar os restos dos meus clientes. Ela não, ela saiu e falou: quero crescer com minhas pemas. Hoje, ela tem um consultório lotado. E eu não indiquei quase nada de clientes para ela, devo ter indic a do no máximo uns 10 clientes nesses 17 anos. E ela nunca reclamou e nunca pediu que eu indic asse.

No começo da carreira solo, como acontece com a maioria das pessoas, Cláudia sofreu um bocado. Havia um grande medo de que a clínica montada por ela e pelos demais estagiários não desse certo, que houvesse uma debandada de clientes depois da saída do Instituto. Mas o grupo de terapeutas soube conduzir o processo de maneira suave e Roberto colaborou, liberando do Instituto os clientes dos estagiários. No entanto, o namoro deu uma certa balançada:

- Para mim foi muito difícil, fiquei muito brava e ressentida. Às vezes a gente discutia por causa de algum assunto do Instituto e, então, os namorados acabavam brigando por causa disso. Aí, no outro dia, um pedia desculpas para o outro e tentava ficarbem. Eu acho que para ele foi diferente porque, nessa época, havia muita soutras coisas com que ele precisava se preocupar.

Por causa do sentimento que ambos nutriam, no final, conseguiram lidarcom aquela situação. Outro momento complicado na vida do casal, que quase inviabilizou a continuação do relacionamento foi quando Roberto disse que não queria ter mais filhos, pois já tinha os filhos dele.

— Aí eu pensei: essa relação tem deadline. Eu não sei quando, como, mas eu quero ter filho, pelo menos se eu puder. Eu tratava essa questão como uma rejeição pessoal: se ele não queria ter filhos comigo, era porque ele não me amava. Eu me vi em um beco sem saída. Nessa época, eu tinha uma terapeuta que me ajudou muito porque eu não podia simplesmente teminar com ele. Isso não seria verdadeiro, eu ia impor de fora uma coisa que não condizia com meus sentimentos. Por outro lado, também não podia vislumbra rum futuro. 
Cláudia compreendia que era difícil para Roberto pensar em ter ma is filhos, eventualmente se separar de novo, sofrer de novo... Mas a compreensão não reduzia a dor que ela sentia todas as vezes em que pensava nisso. J usto ela, que tinha pago um preço muito alto por essa relação, feito grandes rompimentos. Sentia que ele não reconhecia tudo o que ela havia feito, o quanto se a miscara. No entanto, em nenhum momento pressionou Roberto.

- Isso eu aprendi logo: cobrare prender o Roberto era sinônimo de mandá-lo embora. Ele poderia fazere falartudo o que quisesse. E eu não podia falarque isso não estava bom. E nesta altura eu tinha 26 e ele, com 15 a mais, não era nenhum garotinho mandado para quem eu pudesse dizer: não gostei! E a gente sempre teve isso presente: ele tinha mais idade que eu, ele vivia outro mundo. Então eu sempre me achava imatura e comia atrás de amadurecer. E nessa hora acho que isso ajudou muito porque eu consegui não pressioná-lo. Eu sabia que, diante do meu desejo, ele ia pensarum pouco ma is no assunto.

\section{A revolução dos campeões}

Em busca de um pouco de descanso e paz, Roberto, Cláudia, Ricardo e Arthur seguiram para as serras de São Pedro, a 180 quilômetros de São Paulo. Enquanto as crianças brincavam com os monitores do hotel fazenda Fonte Colina Verde, Roberto e Cláudia deram um pulinho ao centro da cidade.

Em volta da pracinha principal, onde fica o tradicional coreto, próximo à pequena igreja matriz, as lojas de artesanato disputavam a atenção dos dois. Durante o ciclo do café, muitas famílias italianas trouxeram para cá a arte do bordado. Seduzidos pela beleza, entraram em uma das lojinhas. Cláudia se distraiu no meio dasatrações. Roberto se afastou sem que a namorada percebesse.

Depois que saíram da loja, ele entregou a ela um singelo presente, pequeno em seu tamanho, gigantesco em seu signific ado. Nas palmas das mã os de Cláudia, um minúsculo par de sapatos ganhavam a verdadeira dimensão que os pés de bebê têm diante da mãe. Nada mais precisava ser dito. O par de sapatinhos 
simbolizava muito mais do que uma oportunidade para que o desejo de Cláudia se rea lizasse, era a renovação de toda as possibilidades da relação.

Quando eu conheci a Cláudia, eu sabia que havia apenas duas coisas que ela queria e eu não: casar e ter filhos. Então, para ter ma is clareza sobre o que eu queria, eu fui tomaro daime. Na verdade, eu bebo o vegetal. Aí eu bebi e entrei no estado de consciência alterado. Então o vegetal me perguntou quais eram os melhores momentos da minha vida. E eu falei que era quando eu estava com os meus filhos. E o vegetal me perguntou: qual o problema de ter mais desses momentos?

O daime ou vegetal é um bebida sacramental, alteradora de consciência, também chamada de caapi, yagé, hoasca e ayahuasca. A bebida é produzida a partir de duas plantas nativas da floresta amazônica. Seu consumo está associado a práticas religiosas ancestrais. Acredita-se que os incas já utilizavam a bebida e que astribos indígenas da Amazônia a empregam desde 2000 a.C.

As seitas religiosas mais conhecidas no Brasil por utilizar a bebida em seus ritua is são o Santo Daime e a União do Vegetal. Assim, os efeitos da bebida estão bastante relacionados aos ritua is religiosos onde se dá o consumo. A crença é de que a bebida a umenta a possibilidade de contato com outros planos espintua is. Em 2004, após 18 anos de estudos, o Conselho Nacional Anti-Drogas do Brasil retirou, em caráter definitivo, a bebida da lista de drogas alucinógenas.

Roberto conta que faz questão de beber o vegetal quando está buscando uma resposta para questões específic as. Em trinta anos, usou o vegetal no máximo umas vinte vezes. Aliás, o lado espintual de Roberto é bastante peculiar e curioso.

Sou um promísc uo espintual, gosto dos mestres espintua is Osho e Sa i Baba, da organização Brahma Kumaris, de tudo... Porisso, tento ir à Índia uma vez por ano, sozinho, para me recarregarcom a sensação de vitalidade.

$\mathrm{Na}$ entrada de seu apartamento, logo após cruzamos a porta, do lado direito, há um pequeno altar bastante eclético. Acima do oratório de madeira nústica escura, repousa uma grande bíblia. Dentro do oratório, destaca-se o crucifixo, três imagens de santos, incluindo aí São Francisco de Assis, um pequeno 
presépio colorido que veio do Peru, gatinhos japoneses, vá rios símbolos indianos e budistas a lém de um pequeno porta-retra to antigo, com três fotos. Em uma delas, Roberto aparece junto com seu pai e, nas demais, surge com seus filhos ma is velhos.

Retomemos à nossa história de amor. Sem os impedimentos para que o casal tivesse filhos, Roberto e Cláudia já podem se casar. O casamento foi marcado para maio de 1995.

- Mas não deu certo porque a mãe do Roberto estava com câncer e a gente viu que não ia dar para casar em maio. Então, marcamos o religioso para setembro.

Os médic os diziam que minha mãe ia morrer a qualquer momento e, em uma sexta-feira, ela se levantou e disse: vocês querem me matar de fome? Ela chamou a Adelaide - a moça que cuidava dela - e pediu para fazer uma macarronada, arroz, feijão... Aí depois de uns dois dias, eu e a Cláudia contamos para ela que a gente tinha adiado o casamento porque ela estava mal. Só lembro que ela disse: vocês são uns irresponsáveis! Minha mãe era muito forte, intensa, acho que eu peguei muito isso dela.

Dona Benedita queria muito aquele casamento, dizia para Cláudia: você faz muito bem para o meu filho. Então, diante de sua cama e das dores que já a impediam de se levantar, fez-se um altar para que dona Benedita pudesse demamar suas bênçãos sobre aquele amor. Era 10 de junho de 1995 quando Roberto e Cláudia disseram sim diante do juiz de paz, aos pés da cama de dona Benedita. $\mathrm{Na}$ inesquecível cerimônia, o pequeno quarto pôde abrigar somente alguns convidados: Rosely, Ricardo, Arthure os pais, a vóse a imã de Cláudia.

Depois de dar suas benções, foi como se dona Benedita compreendesse que poderia, enfim, seguir sua sina. Em agosto, a mãe de Roberto morreu.

Quando descobriu que dona Benedita estava com câncer e precisava se intemar imediatamente para fazer uma cinurgia, Roberto recorreu ma is uma vez ao vegetal. Queria sabero significa do daquela situação. 
Eu fui beber o vegetal no sábado, minha mãe intemava no domingo para operar na segunda. Aí o vegetal falou assim: seu pai morreu de enfarte porque vocês estavam resolvidos, você não precisa conversar mais nada na hora da morte dele. Mas você tem muita coisa para resolver com sua mãe. Então, a proveite esse tempo que ela ainda tem de vida.

No domingo, Roberto se intemou com dona Benedita no hospital e ficou ali durante os sete dias que ela permaneceu no local. Mergulhou naquela relação, que saiu de lá renovada.

Em seu livro "Heróis de Verdade", Roberto relata essa história como se o vegetal fosse um mestre. É com essa habilidade de recriar suas memónias que ele consegue universalizar seus a prendizados, para poder repassá-los a os leitores sem correr o risco de ser mal interpretado. Afinal, não são todos que aceitam a validade das experiências vividas com o daime e, devido a habilidade de poetizar as situações de sua vida, Roberto consegue alcançar mais pessoas.

Mas voltemos, mais uma vez, à nossa história de amor. Não pense que ela já acabou, ainda falta o casamento religioso. Mas Roberto não tinha como se casar no religioso porque era separado. Em um domingo, enquanto Cláudia e Roberto estavam na piscina do apartamento, ele teve uma idéia para solucionar o problema:

- Pegue a lista telefônica, Cláudia, procure aí igrejas.

Então, eles começaram a ligar e perguntar:

- Casa divorciado aí?

Até que encontraram um nome que chamou a atenção: Igreja Ecumênica Universal.

- Era a nossa cara! Dava para ter budista, os a migos judeus, os discípulos do Osho, do Sai Baba, do budismo, do zen budismo... Ele ligou para, foi lá e o padre topou!

Fina Imente, o casamento religioso foi marcado para o dia 16 de setembro.

- E a gente brigava muito nessa época porque eu não entendia o que ele queria. Um dia eu entendi e acabei comprando a idéia. Ele fez um texto assim para 
o convite: depois de 5 anos juntos a gente descobriu que nosso amor é definitivo e etemo e por isso a gente quer se casar e convidarvocês... E eu via bilizei um convite muito louco: todo em papel reciclado, que na época era um parto achar, escrito à mão, com a minha letra. Escrevi o texto com uma pena, aí fizeram um fotolito, imprimiram no papel vegetal e colocaram no que seria o envelope, que era de papel de algodão. Foi a coisa que ma is deu trabalho no casamento! Antes, eu só conhecia aqueles convites de casamento tradicional, em que aparecem os nomes dosnoivose dospais.

Mais uma vez, Roberto apresentava o mundo do diferente à Cláudia .

\section{Heróis de verdade}

Perto daquela moçada de 20 e poucos anos, a garota de 14 anos, que vivia na barra da saia da mãe, vislumbrou a possibilidade de serindependente, de morar sozinha em uma cidade grande, de ter o próprio carro. Foi um final de semana inteininho ao lado daquele pessoal, em um sítio próximo à Bragança Paulista. A idéia de levá-la para lá nasceu do imão.

— Então minha mãe fez uma maletinha com as coisas que achava que eu ia precisare lá fui eu com o Roberto!

Na situação inusitada, Rosely admirou-se com a liberdade daquele pessoal. Chamou sua atenção a garota que morava sozinha, dirigia o próprio carro e deu carona a ela e a Roberto. Um novo mundo se abriu diante de seus olhos.

- Eu acho que foi intencional, afinal, por que ele ia querer uma imã pentelha junto?

Roberto sabia bem como Rosely era criada pela mãe, sempre muito protegida. Para se ter uma idéia, dona Benedita comprou uma toalha xadrez vermelha para a filha quando ela estava com cinco anose falou:

-É para o seu enxoval!

Coube a Roberto o papel de levar Rosely para um universo diferente. Um papel que lhe é muito confortá vel e conveniente. Aliás, quando comecei a estudar a possibilidade de trabalhar na Editora Gente, também passei por uma experiência 
similar. Minha função seria lapidar os textos de Roberto, mas eu não tinha a menor idéia do que isso signific ava. Tratava-se de um exercício profissional completamente novo para mim. Em um primeiro momento, me senti desconfortável. Cheguei a imaginar que havia algo de estranho naquela história, afinal, de quem seria a autoria daqueles escritos?

Decidi me amiscar e, rapidamente, percebi que meu trabalho não era colocar no papel o que Roberto seria incapaz de escrever, mas mergulhar em seus textos para identificar lacunas e oportunidades de aprimoramento. O que houve durante a produção do livro "Heróis de Verdade" foi um intenso vai-e-vem de obsenvações, um verda deiro compartilhar de idéias sobre o que se escrevia. Tudo o que eu alterava ficava marcado em letras maiúsculas coloridas para que ele pudesse rapidamente identificare opinar.

Eram tantas idas e vindas que às vezes eu achava que aquele livro nunca ia acabar. Enquanto entendesse que ainda podíamos melhorar, Roberto não parava de mudar o texto. Com o convívio, fui compreendendo melhor o que significava uma das frase que ele costuma repetir de vez em quando:

O segredo do sucesso do Roberto é ser sem talento. Ele sabe que não é bom em nada e supre isso com muito trabalho. Vai mexendo nas coisas a té elas fic arem lega is.

Com Roberto, aprendi a encarar a literatura de auto-ajuda com novos olhos e passei a compartilhar de sua loucura em acreditar que esses textos podem mudar a vida de sereshumanos.

Se eu escrever de um jeito que toque as pessoas, elas vão fazer uma reflexão sobre o papel delas no mundo, sobre o modo como estão vivendo e poderão se transformar. 


\section{Contribuições enc ontradas durante a viagem}

Siga o que é sublime para você. A vida heróic a consiste em viver a aventura individual.

J oseph Campbell

"Uma história pessoal: um dia entrei em uma Igreja após uma entrevista e, enquanto observava a arquitetura do local, uma velhinha me chamou. Perguntou a hora e pediu que eu me sentasse. Mais que depressa sentei, sentindo a necessidade que aquela pessoa tinha de falar. Mas, à medida que ela, espontaneamente, contava sua história, fui me sentindo incomodada. Eu comecei a fazer perguntas que me levavam a conhecer o que de 'fora do comum' havia na vida daquela velhinha. Quando percebi que não conseguia ouvi-la despretensiosamente, senti-me como um usurpador que, sem ter direito de penetrar na vida de ninguém, rouba histórias..."

Escrevi o texto acima em junho de 1999, quando cursava a matéria "Livro Reportagem I", em meu primeiro encontro com o professor Edvaldo Pereira Lima, durante uma aula de graduação em jomalismo na Escola de Comunicações e Artes da USP.

Achei este texto ao fazer um trabalho "arqueológico" em meu microcomputador. Quando comecei a pensar de onde tinha surgido a questão que desenvolverei na minha Dissertação de Mestrado. Era como se não houvesse uma pedra fundamental neste castelo de reflexões, como se a questão que me move agora sempre estivesse ali, presente na minha vida, especialmente nos momentos em que eu ouvia um relato.

O que eu sentia nesses momentos? Não era dor por estar diante de alguém escarafunchando detalhes da memória. Mas um sentimento de incômodo, talvez por temer o poder que o registro de histónias me delegava, talvez devido a o receio de fazer um outro ser humano sofrer com algumas recordações desagradá veis que estavam, até aquele momento, fechadas dentro da mochila colocada nas costas. 
E, por minha insistência, aquela bagagem era tirada de seu cômodo lugar. Espaços escondidos, cheios de lembranças amareladas e amassadas, eram descobertos. Neste processo de releitura da própria história, aquele ser humano acabava se deparando, inevitavelmente, com recordações que preferina jamais ter reencontrado. Mas também com prazerosas lembranças.

Provocar o reencontro de uma pessoa com as cenas de seu passado, a lgumas delas já meio esquecidas, me gerava um certo desconforto. A sensação de que eu tinha a chave do portão daspalavras na mão e de que isso me dava a a rrogância de revistara bagagem de alguns transeuntes me dava um certo medo. Medo do desconhecido que habitava aquelas mochilase também a minha.

Esse desconforto me atingia especialmente quando o levantamento de informações precisava ser mais a profundado - o que aconteceu quando produzi textos seguindo a proposta do J omalismo Literário - e eu estabelecia uma relação diferenciada com os entrevistados. Apesar das sensações desagra dá veis durante as a purações para a produção desses textos, eram esses mesmos tra balhos que me permitiam - de maneira ma is evidente - exercer minha autoria, crescer intelectual e emocionalmente e me sentir ma is humana e feliz. Assim, foi inevitável que, com o tempo, eu mergulhasse na produção de maise mais dessas na rativas, enfrentando os temores e estabelecendo um maior número de relaçõescom diferentes pessoas.

Durante esse trajeto, fui aprendendo a lidar melhor com o desconforto e a compreender as inúmeras possibilidades que existem no encontro estabelecido entre os jomalistas e suas fontes. Nesta Dissertação, pretendo mostrar de que maneira empreendi essa jomada em busca dessa compreensão.

Ressalto que meu propósito não é oferecer um modelo de abordagem, de criação de empatia ou de aproximação entre esses dois seres humanos. O que pretendo é estudar as possibilidades que existem na construção da relação entre jomalistas e suas fontes, compreender de que maneira essa oportunidade de encontro entre duas subjetividades pode ser melhor aproveitada. A hipótese é de que a relação entre jomalistas e fontes possibilita o surgimento de um campo 
intersubjetivo propício para a troca de uma série de informações que podem, inclusive, favorecer a construção de uma narrativa jomalística diferenciada.

\section{Berços de um contare de um escutar}

Quando a na lisa mos na rrativas joma lístic as que abarcam histórias de vida, nos deparamos com um trabalho de apuração de informações que requer um escutar específico: o escutar de um relato de um ciclo de vida, ou de episódios de vida, caso dos perfis; ou a inda o escutar de uma vida inteira, caso da biografia.

Uma das caracteństicas peculiares dos relatos ouvidos pelos jomalistas nas histórias de vida é que sempre se está diante de um contar que é fruto do que se sucedeu antes desse contar. E quem conta sua história a o jomalista - quer seja sobre as sensações que estão tomando conta do corpo no quase instante da fala, sobre um bombardeio que começou poucos minutos atrás ou uma guerra que terminou há anos--, sempre está falando a partir de uma percepção. Primeiro, o ser humano precisa percebera situação, o fato, a emoção, ou o que for, registrando o acontecido, para só então ser capaz de enunciá-lo. O discurso nasce a partir da percepção, é a percepção que suscita o discurso.

"Diz-se que um homem nasceu no momento em que aquilo que, no fundo do corpo matemo, não passava de um visível virtual toma-se ao mesmo tempo visível para nós e para si" (MERLEAU-PONTY, 1980, p. 92). A frase de Merleau-Ponty traz em seu ceme a reflexão do autor sobre o que é a percepção. $O$ mundo silencioso da percepção, para Merleau-Ponty, surge a partir da relação do homem com seu próprio corpo. Uma relação complexa, em que somos, ao mesmo tempo, videntes e visíveis.

O enigma reside nisto: meu como é ao mesmo tempo vidente e visível. Ele, que olha todas as coisas, também pode olhar a si e reconhecer no que está vendo então o 'outro lado' do seu poder vidente Ele se vê vidente, toca-se tateante, é visível e sensível por si mesmo. (Ibid., p. 88) 
Ou seja, você traz em seu corpo, ca ro leitor, a marca visível da sua vidência, a marca tocada de seu toque, a marca escutada de sua escuta... $E$, por ma is que você tente, jamais se olhará como olha o outro, se tocará como toca o outro, se escutará como escuta o outro... Mora em cada serhumano a impotência de "ser" o outro.

Para Merleau-Ponty, essa impotência do ser humano não é um fracasso, mas atesta sua capacidade de se ouvir por dentro e porfora, de se tocar pordentro e por fora, de se ver por dentro e por fora... A um só tempo, o dentro também é o fora. É assim que o filósofo revela a reflexividade do corpo, conceito fundamental na sua definição da percepção. Pois, se eu assisto ao outro do meu lugar, e sou incapaz de ver o que ele vê, a própria visão do outro atesta os limites da minha visão. E, exatamente por ocupar um lugar no mundo, é que posso reconhecer que cada perspectiva é única, havendo assim uma coexistência de perspectivas.

Nesse mundo solitário da percepção, como sou capaz de me comunicar com os outros? Ora, pela linguagem. O mundo silencioso da percepção solicita o mundo invisível das palavras. É pela linguagem que consigo partilhar a minha perspectiva com o outro. Por isso, minha linguagem sempre se refere a algo, mas nunca é o algo em si.

Toda expressão sempre me aparece como um vestígio, nenhuma idéia me é dada na transparência e todo esforço para fecharnossa mão sobre o pensamento que habita a palavra deixa apenas um punhado de material verbal entre nossos dedos. (Ibid., p. 133)

É como se a própria definição de linguagem carregasse em si uma espécie de memória do que deseja expressar. Isso nos leva a concluir que a plenitude da expressão nunca é conseguida. Mais uma vez, essa impotência não é vista por Merleau-Ponty como um empecilho, mascomo o que nos dá a possibilidade de nos comunic armos. Afinal, se houvesse uma expressão plena, incontestá vel, a ssim como uma percepção plena, por que precisańamos nos comunicar? se você pudesse 
ocupar o lugar do "outro" no mundo, se já soubesse as perspectivas do "outro", onde estaria a graça de ouvi-lo? Onde estaria a graça de poder compartilhar da sua perspectiva, do seu olhar, do seu sentir, enfim, da sua experiência de mundo?

Tomando como partida este pequeno resumo do pensamento de MerleauPonty, podemos pensar que, quando um jomalista esta diante de alguém que the conta uma história, está também diante de alguém que lhe conta sua perspectiva de mundo por meio da linguagem, alguém que viveu algo (não importa se de maneira física, psicológica ou metafórica) e é capaz de se pronunciara partir dessa experiência. Alguém que nos conta, em última instância, suas memónias.

Mas de onde nasce o chamado para o lembrar? Será que o que estava guardado em nossa mente, oculto até para nós mesmos, vem à tona poracaso?

Para Ecléa Bosi, "é do presente que parte o chamado ao qual a lembrança responde" (1999, p. 48). Nesse sentido, quando alguém se dispõe a narrar uma história para o jomalista, a história a ser narrada não estava de antemão pronta na mente de quem narra, mas vai se construindo no próprio contar.

Na maior parte das vezes, lembrar não é reviver, mas refazer, reconstruir, repensar, com imagens e idéias de hoje, as experiências do passado. A memória não é sonho, é trabalho. Se assim é, deve-se duvidar da sobrevivência do passado, 'tal como foi', e que se daria no inconsciente de cada sujeito. A lembrança é uma imagem construída pelos materiais que estão, agora, à nossa disposição, no conjunto de representações que povoam nossa consciência atual. Por mais nítida que nos pareça a lembrança de um fato antigo, ela não é a mesma imagem que experimentamos na infância, porque nós não somos os mesmos de então e porque nossa percepção alterou-se e, com ela, nossas idéias, nossos juízos de realidade e de valor. (BOSI, 1999, p. 55)

Ou seja, as memónias não estão de antemão prontas na mente de quem as conta, mas se constroem no próprio lembrar. É o contar das nossas experiências que nos leva à construção desse próprio contar: "Para o sujeito falante, exprimir é 
tomar consciência; não exprime somente para os outros, exprime para que ele próprio saiba o que ele visa" (Ibid., p. 134).

Compartilhando da visão de Merleau-Ponty, a qual não vê nas impotências humanas suas limitações, mas suas possibilidades, podemos compreender que é devido a essa incapacidade de recuperar o passado tal como ele foi que existe a abertura para novasleituras sobre nossas vidas.

Partindo dessa abertura para novas leituras, a qual corresponde à compreensão merleau-pontyana da coexistência de perspectivas, o professor J oão Augusto Frayze-Pereira, do Instituto de Psicologia da Universidade de São Paulo, propõe que o discurso psicanalítico seja compreendido sob um novo ponto de vista: constituindo-se como recriação da realidade a se fazer sempre. Nessa visão sobre a psicanálise, o psicanalista não é compreendido como um arqueólogo em busca dos tesouros escondidos do paciente, mas como um profissional capaz de acompanhar o paciente na criação de novas realidades, amparando-o na construção de um sentimento de realidade.

É este ponto de vista a respeito da psicanálise que, acredito, tem muito a contribuir com o jomalismo. Tal como o discurso psicanalítico e a memória, o texto jomalístico não é fruto direto do que se passou, do que se ouviu, viu, viveu, sentiu, mas uma construção a partir de instrumentos próprios do presente.

Se a té a memória não é um retrato fiel do passado, por que o jomalismo e a psicanálise o seriam? Mas será que o fato de o jomalismo não se constituir em um retra to fiel da realidade implica uma falsificação?

A função da lembrança é conservar o passado do indivíduo na forma que é mais apropriada a ele. O material indiferente é descartado, o desagradável, a lterado, o pouco claro ou confuso simplifica-se por uma delimitação nítida, o trivial é elevado à hierarquia do insólito; e no fim formou-se um quadro total, novo, sem o menor desejo consciente de falsificá-lo. (Ibid., p. 68) 
Ao que tudo indica, a questão da impossibilidade de um retrato fiel da realidade, do passado, ou do que quer que seja, não nos coloca diante de uma "falsificação" do mundo, mas diante de caracteństicas intŕnsecas de nossa realidade: multiplicidade infinita e transcendência de sentidos, de significados, de perspectivas.

Essa visão da realidade se soma às dema is idéias apresentadas no primeiro capítulo e conduzem à negação da existência de um jomalismo objetivo e ao questionamento de todo um arcabouço de conceitos e idéias positivistas que levaram à elaboração de concepções que separam sujeitos e objetos, que sentenciam a existência de "uma verdade", que trabalham com oposições estanques entre subjetivo e objetivo, realidade e fantasia, mentira e verdade, individual e coletivo etc.

Assim, a pessoa que conta algo ao jomalista para a composição de uma história de vida elabora o discurso no momento mesmo em que o fala. É um sujeito que trabalha para articular suas memórias, que interage com o interlocutor na construção do que está sendo dito. Um sujeito que, conseqüentemente, é ativo e passivo a um só tempo: ativo porque constrói um discurso e passivo porque seu relato surge a partir do a tendimento às demandas do joma lista.

Neste ponto, vamos voltar a Ecléa Bosi para evidenciar porque, no caso das histónias de vida, a veracidade é uma palavra fora de contexto: "Nosso interesse está no que foi lembrado, no que foi escolhido para perpetuar-se na história de sua vida" (p. 37). Ou seja, nas histórias de vida, o que importa é o que está sendo dito, o que foi lembrado. Não há uma verdade a ser descoberta naquelas memórias, pois a verda de se constrói no dizer.

Afinal, se consideramos que há um mundo verdadeiro e várias interpretações possíveis, ainda estaremos supondo que existe uma verdade intacta em algum lugar, conforme explica Ana Taís Martins Portanova Barros. Isso seria extremamente contraditório a tudo o que foi dito antes sobre a construção da memória e da percepção humana, que não lidam com uma realidade dada, mas uma realidade que se constrói no dizer, no sentir. Acreditar que o mundo é dado 
independentemente do sujeito, é continuar a conviver com o paradigma positivofunc iona lista.

A realidade não é algo que está aí o tempo todo, esperando ser descoberta; ela tem de ser inventada. Ela não existe sem a subjetividade, e uma vez instaurada, nunca é a mesma: depois que a percebemos, nossa percepção a altera, e viceversa, de modo a ser impossível atribuir a alguma ponta desse processo a anterioridade fundadora. (BARROS, 2003, p. 210)

Se tomarmos o mundo como à parte de nossa percepção, estaremos correndo o risco de continuar a fazer uma ciência descamada, longe do mundo sensível que se apresenta a nós diariamente.

Dizer que o mundo é, por definição nominal, objeto $X$ das nossas operações é levar a o absoluto a situação de conhecimento do sábio, como se tudo o que foi ou é nunca houvesse sido senão para entrar no laboratónio. (MERLEAU-PONTY, 1980, p. 86)

Assim, para nos lançarmos à pesquisa ao modo de Merleau-Ponty, precisamos compreender o mundo da percepção, concebendo o pensamento como corporal, "única maneira de formular perante o entendimento a união corpo e a lma" (Ibid., p. 99).

\section{Considerações metodológicas}

Agregando as contribuições teóricas de Merleau-Ponty e Ecléa Bosi, compreendemosque:

- ocupamos uma posição única no mundo e, que, graçasa isso, temos a satisfação de compartilhar nossa perspectiva de vida com outros seres humanos;

- nossas lembranças e percepções não partem de uma memória e de um mundo pré-existentes, mas se constroem no lembrar e no contar. 
Diante disso, como fazer um trabalho de campo sobre as possibilidades existentes na relação estabelecida entre jomalistas e fontes? Se ocupamos uma posição única no mundo, seria preciso eu apresentar neste trabalho a minha leitura sobre essas possibilidades. Ou seja, o mais coerente seria empreender uma pesquisa de campo em que eu pudesse me envolver de maneira direta para poderfalar a partir das minhas próprias experiências. Ao partir para campo com esse olhar direcionado para a relação, eu poderia executar um trabalho direcionado para analisa r essa questão.

É a mesma discussão trazida para a ciência pela física quântica: se desejo medir o elétron como uma onda, preciso de um aparato medidor de ondas. Se eu medi-lo com um aparato medidor de partículas, pode ser que eu chegue à conclusão de que o elétron não é uma onda.

Assim sendo, de pouco adiantaria, em minha pesquisa, ir a campo analisar como outros jomalistas lidam com suas fontes. Eu estaria buscando um aparato inadequado, pois esses outros jomalistas podem não dar à essa questão a mesma importância que eu dou, podem simplesmente ignorá-la. É claro que eu acabaria encontrando diversos indícios importantes, mas não seria uma pesquisa coerente com a linha teórica que apresentei até aqui, especialmente levando em conta as contribuições de Merleau-Ponty e Ec léa Bosi.

Acredito que a opção metodológica ma is condizente com as concepções apresentadas era a realização de um trabalho de campo em que eu fosse minha própria cobaia. Assim, partindo de minha posição única, eu poderia evidenciar as possibilidades que enxerguei na relação que estabeleci com o protagonista da história na rrada. Indo a campo com a preocupação de mergulhar na relação com a fonte, eu seria capaz de ir ma is a fundo em meu estudo.

Mas é claro que há riscos e limitações nessa escolha metodológica, por isso, faço coro com Rogério Christofoletti:

Sei que ao optar pelo caminho de ser cobaia de mim mesmo, corro os riscos que a interpretação impõe num processo de leitura. Não ignoro o fato de que os 
leitores possam considerar minha atitude - a nalisar o próprio texto para referendar minhas proposições - um tanto suspeita; que possam ver nisso um exercício fácil e pretensioso; que vejam aqui um contra-senso aos procedimentos científic os. Entendo isso, mas absorvo tais críticas em nome da opção metodológica que fiz. (2004, p. 217)

Como assegura o próprio Rogério, remexer nas próprias vísceras nos permite repensar nossas práticas de reportagem e refletir sobre o profissional que queremos continuar construindo. "Ser cobaia de si mesmo pode parecer confortável, mas traz em si muitos perigos ta mbém. Um deles: deixar-se cortar na própria came." (Ibid., p. 218)

Assim, depois de fazer minha opção metodológica, o próximo passo foi escolher a pessoa que me contaria sua história. Eis a grande dificuldade: eu não poderia fazer uma opção totalmente aleatória, levando em conta simplesmente que, em qualquer tipo de produção jomalística, há um envolvimento entre o jomalista e sua fonte. Nesse sentido, qualquer tipo de escolha que eu fizesse seria pertinente e, ao mesmo tempo, questionável.

Foi então que o fenômeno da sincronicidade10 veio contribuir com essa pesquisa. Quando estava chegando a data final para o início do estudo de campo, surgiu a oportunidade de ir trabalhar na Editora Gente com os textos de Roberto Shinyashiki. Inicialmente, não percebi a oportunidade que se escondia atrás de meu novo emprego. Apenas depois de cerca de um mês é que comecei a vislumbrar o quanto a relação que eu estabelecia com Roberto era extremamente próxima. Afinal, além de conviver com ele no dia-a-dia, eu também lidava com seus textos. Aos poucos, fui chegando à conclusão de que aquela relação era a mais próxima que eu já havia estabelecido com qualquer pessoa, excluindo-se, é claro, meus familiares, amigos e dema is pessoas de meu círculo de

\footnotetext{
${ }^{10}$ Termo criado por Carl Gustav J ung para designara aparição simultânea de dois acontecimentos, liga dos pela signific ação, mas sem relação causal. "A sincronic idade, portanto, significa, em primeiro lugar, a simulta neidade de um estado psíquico com um ou
} 
convívio pessoal. Além disso, apesar de ser extremamente conhecido, não havia sequer um perfil recentemente escrito sobre Roberto.

Resultado: elaborei um perfil a partir do ponto de vista mais próximo a que já cheguei de uma fonte. Dessa forma, ficou mais fácil ter um parâmetro de comparação dessa situação em relação a todas as demais que já vivi para, assim, ana lisar as possibilida des e os riscos existentes qua ndo um autor está muito perto de seu personagem. Trabalhar no limite máximo possível de proximidade a que já cheguei me ajudou a enxergar as disparidades desse trabalho em relação aos demais. É mais fácil distinguir as diferenças entre um doce insosso e o leite condensado, entre um afago e um tapa, entre a luz e a escuridão, entre o agudo e o grave, entre um perfume e um esgoto. Por isso, nada melhor do que trabalhar no limite.

Explícitas minhas escolhas em relação ao trabalho de campo, resta, agora, justificar o caminho teórico que percorreremos daqui em diante. Na esfera do J omalismo Literário, não encontrei nenhum estudo centrado especificamente na relação jomalista/fonte. Há, é claro, menções esparsas sobre essa questão, mas nada que se aprofunde na discussão. Por isso, foi inevitável me embrenhar por outra sesferas do conhec imento.

Nesse caso, como há uma grande bibliografia abrangendo relações estabelecidas entre terapeutas/pacientes, médicos/pacientes, professores/alunos, precisei fazer um recorte teónico. Para isso, fiz uma indaga ção bastante condizente com o perspectivismo de Merleau-Ponty: quais concepções teóricas podem ser adotados para me ajudar a compreender a relação que construí com a pessoa que me contou sua história? Ou seja, utilizei um critério de seleção teórico bastante simples, que também pode ser explícito por meio da seguinte pergunta: há nessa teoria estudada algo que ilumina meu trabalho de campo?

A partir das luzes que enxerguei em um levantamento bibliográfico inicial, selecionei as abordagens teóricas que me pareciam mais iluminadoras e as momentâneo e, em certa s circ unstâncias, ta mbém vic e-versa" (J UNG , 2005, p. 19). 
apresentarei, a seguir, em separado umas das outras. O principal elo que une essas abordagensé a questão do inter-humano, do caráter que une uma subjetivida de à outra. No próximo capítulo, farei a síntese teóric a dessas contribuições.

\title{
Contribuições de Martin Buber
}

\begin{abstract}
Quando, seguindo nosso caminho, encontramos um homem que, seguindo o seu caminho, vem a o nosso encontro, temos conhec imento somente de nossa parte do caminho, e não da sua, pois esta nós vivenciamos somente no encontro. Martin Buber
\end{abstract}

Martin Buber é conhecido como o criador de uma verdadeira filosofia do diálogo. Para Buber, a relação, o diálogo, é fundamental para a compreensão da existência humana. Segundo ele, lidamos com o mundo de duas maneiras: pela experiência e pela relação. "O mundo como experiência diz respeito à palavraprincípio Eu-lsso. A palavra-princípio Eu-Tu fundamenta o mundo da relação" (1979, p. 6).

Nesse sentido, quando agimos a partir da palavra-princípio Eu-Isso, consideramos o que se apresenta a nós como um objeto, comparável a outros objetos. Algo que pode ser ordenado, descrito, decomposto objetivamente. Aliás, nada pode ser integrado na soma de conhecimentos a não ser na qualidade de um Isso.

Por outro lado, quando estamos no plano da palavra-princípio Eu-Tu, estamos no plano da relação.

Quem está na relação participa de uma atualidade, quer dizer, de um ser que não está unicamente nele nem unicamente fora dele. Toda atualidade é um agir do qual eu participo sem poder dele me apropriar. Onde não há participação, não há atualidade. Onde não há apropriação de si não há atualidade. A participação é 
tanto mais perfeita quanto ma is o conta to do Tu é ma is imediato. (BUBER, 1979, p. 7374)

Para Buber, o domínio da relação é também o domínio da subjetividade, onde o Eu se conscientiza simultaneamente de seu vínculo e de sua separação em relação ao Tu. O momento da relação é único, pois é como se nada mais existisse diante de nós, tudo o mais vive na luz daquele Tu e os sentimentos simplesmente acompanham essa relação, que não se realiza na alma, mas entre o Eu e o Tu. "O Tu se a presenta a mim. Eu, porém, entro em uma relação imediata com ele. Assim, a relação é, a o mesmo tempo, escolher e ser escolhido, passividade e atividade" (Ibid., p. 89).

Essas duas maneiras diversas de lidarmos com o mundo (Eu-Tu e Eu-Isso) são processos que se altemam. Para Buber, a melancolia e a grandeza de nosso destino é que cada Tu deve tomar-se irremediavelmente um Isso. Pois só o Isso é descritível, decomponível, classificável... Só o Isso nos pemite a existência do conhecimento, da obra, da imagem, do modelo.

Assim, a contemplação autêntica do Tu é sempre breve, pois o outro se revela a mim no segredo da ação mútua para, depois, se tomar um Isso. "Cada Tu, a pós o término do evento da relação deve necessariamente se transformar em Isso. Cada Isso pode, se entrar no evento da relação, tomar-se um Tu" (p. 38).

Para explicar essa constante passagem da palavra-princípio Eu-Isso para EuTu e vice-versa, Buber recorre a uma imagem simbólica bastante esclarecedora: “O Isso é a crisálida, o Tu a borboleta. Porém, não como se fossem sempre estados que se altemam nitidamente, mas, amiúde, são processos que se entrelaçam confusamente numa profunda dualidade" (p. 20).

É no face-a-face do Eu-Tu que o ser se revela, mas toda a resposta amarra o Tu ao mundo do Isso. "Somente o silêncio diante do Tu, o silêncio de todas as línguas, a espera silenciosa da palavra não formulada, indiferenciada, pré-verbal, deixa ao Tu sua liberdade..." (p. 46) Somente quando duas subjetividades passam 
do plano do Eu-Tu para o plano do Eu-Isso, dá-se a experiência e pode-se dizeralgo a respeito do que foi vivido.

Assim como a melodia não se compõe de sons, nem os versos de vocábulos ou a estátua de linhas - a sua unidade só poderia ser reduzida a uma multiplicidade por um retalhamento ou um dilaceramento - assim também o homem a quem eu digo Tu. Posso extrair a cor de seus cabelos, o matiz de suas palavras ou de sua bondade, devo fazer isso sem cessar, porém ele já não é mais meu Tu. (p. 9-10)

Todas essas colocações de Buber nos remetem a pensar que, na elaboração de uma histónia de vida, quer seja ela um perfil ou uma biografia, é extremamente favorável a ocorrência de um encontro do tipo Eu-Tu entre o jomalista e a pessoa que lhe conta sua história. A partir dessa relação, em que a compreensão do outro atinge um plano indefinível, corre-se um menor risco de que o texto resultante reduza esse Tu a um mero objeto. Afinal, mesmo depois que a relação Eu-Tu cessa, permanece uma semente desse encontro em cada um desses sujeitos. Semente essa que irá geminar o futuro texto, mesmo sendo necessário, para se descrever esse Tu, lidar com ele na forma de Eu-Isso.

No caso das entrevistas que realizei com Roberto, Cláudia e Anderson, senti que esse processo Eu-Tu aconteceu. Tanto que, ao fim de cada uma dessas conversas, a sensação que eu tinha era de que o tempo havia parado. Independentemente do que acontecia à nossa volta - estive com Roberto em um ba rulhento Fran's Café, com Cláudia em seu silencioso consultónio de psicoterapia, com Anderson em um movimentado restaurante - era como se nada mais existisse além de nós.

No entanto, por não depender a penas da vontade dos sujeitos, há casos em que a vivência Eu-Tu poderá não acontecer. Percebi que o processo que se deu com Marga ret e Rosely foi um pouco diferente, embora as dua sentrevistas tenham acontecendo nomalmente e ambas terem sido muito receptivas. Mas não senti que um encontro tão profundo se deu. A meu ver, isso não trouxe grandes prejuízos 
ao perfil, tendo em vista que Marga ret e Rosely não eram as personagens principa is da história que escrevi.

Para Buber, por mais que nos esforcemos no estabelecimento de uma relação, há sempre algo de incontrolável e misterioso que pode levarou não a este acontecimento: "O Tu encontra-se comigo por graça; não é através de uma procura que é encontrado" (p. 12). Ou seja, o jomalista precisa a prender a conviver com o inefável durante a apuração, no momento de lidar com os outros seres humanos que lhe contarão sua s histónias.

Outra contribuição importante de Buber para a compreensão do encontro humano está no conceito de reciprocidade: "Relação é reciprocidade. Meu Tu atua sobre mim assim eu atuo sobre ele. Nossos alunos nos formam, nossa sobras nos edificam (...) Nós vivemos no fluxo torrencial da reciprocidade universal, irremedia velmente encerrados nela “ (p. 18).

É no interior da relação Eu-Tu que o eu verdadeiramente se realiza. É aí que os seres se revelam um ao outro e se confimmam por meio da linguagem autêntica, de um diálogo genuíno.

O mestre ajuda os discípulos a se encontrarem e, nas horas de depressão, os discípulos ajudam o mestre a reencontrar-se. O mestre inflama as almas dos discípulos; e eles o rodeiam e iluminam. O discípulo pergunta e, pela forma de sua pergunta, evoca, sem o saber, uma resposta no espíito do mestre, a qual não teria nascido sem essa pergunta (BUBER, “Histórias do Rati", p. 25, Apud BUBER, 1979, p. XXXIX)

Nesse sentido, quando um jomalista faz uma pergunta ou uma colocação a uma fonte, muitas vezes evoca uma resposta da fonte que jama is teria nascido sem aquela pergunta. O processo inverso ta mbém acontece: uma colocação da fonte evoca no jomalista algo que ele jama is pensa ria sem aquela intervenção. É por isso que, por mais que exista uma pauta pré-estabelecida, a verdadeira matéria nasce quando um Eu se encontra com um Tu. É aí que o processo de compreensão se dá: neste imprevisível momento chamado encontro. "Essas duas subjetivida des têm de 
conhecer-se mutuamente para que dessa interação resulte a lgo novo, vivo, que traga à tona uma descoberta, uma revelação que dependa exclusivamente desse encontro" (YAKHNI, 2001, p. 23).

Durante a apuração de uma matéria, somos acostumados a pensar que é apenaso jomalista que descobre algo, que somente a ele é dada essa dádiva, que ele é o senhor desse processo e o mantém sob total controle. Nos esquecemos de que, por se relacionar com outros seres humanos, a lém de ser impossível ter total controle sobre o que acontecerá durante a apuração, estabelecemos uma relação recíproca, em que o outro também pode ser levado a fazer descobertas sobre sua própria história.

Durante a entrevista com Cláudia, em determinado momento, comento sobre os comentánios, os puxões de orelha, as dic as que Roberto dá às pessoas que trabalham com ele, no intuito de que elas se desenvolvam, e pergunto se ele também faz isso na vida pessoal. O início da resposta de Cláudia é extremamente signific ativo: "Olha, deixa eu pensar... Dessa forma eu nunca tinha olhado. É, não sei, assim... Eu acho que faz sim. Eu acho que faz sim. E isso é uma das causas das dificuldades que a gente tem porque como ele já é pai há mais tempo..."

Ao dizer que nunca havia olhado para aquela questão da maneira como the apresento, Cláudia nos mostra o quanto uma relação entre jomalista e fonte pode gerar descobertas não apenas nesse profissional que vai a campo em busca de compreensão, mas também nas pessoas que interagem com ele durante essa trajetónia.

Assim, o texto que o jomalista produz a partir do encontro com a fonte nasce, na maior parte das vezes, de uma descoberta mútua estabelecida por essas duas subjetividades. Uma descoberta que só se tomou possível porque aqueles dois seres humanos se encontraram.

Em sua Dissertação de Mestrado, Sarah Yakhni afima que, do ponto de vista dialógico, "o sentido aparece entre nós e as coisas". Maria Teresa Cruz corrobora com essa idéia ao afima que "a obra literária não pode ser completamente identificada com o texto ou com a realização do texto, mas sim, na realidade, 
residir a meio caminho entre ambos"11. Parece que, assim como a obra literária, o sentido da produção jomalística também não está nem no joma lista, nem na fonte, mas nesse meio do caminho. Levando-se em conta todas as pedras que existem em todosos meios de caminho...

A própria maneira como um jomalista se relaciona com sua fonte, leva-o à vê-la sob uma determinada perspectiva: presenciando cenas e mantendo contato com pessoas que, se o jomalista lidasse com aquela fonte de uma outra forma, não seria possível. Ou seja, ao conviver com Roberto sob a perspectiva de uma funcionária da Editora Gente, presenciando-o em uma das esferas de seu cotidiano, acabei observando cenas e construindo relações com pessoas como Anderson, Margaret, Rosely e Cláudia. Se eu não convivesse com ele naquele a mbiente, eu a té poderia entrevistar essas mesmas pessoas, mas passaria a ocupar uma posição diferente em relação a elas. Iria entrar em contato com Roberto sob uma outra perspectiva, que me levaria a enxergá-lo de uma maneira diversa a que o enxerguei. Nem ma is nem menos verdadeira, a penas diversa.

A vida da gente, os textos, as leituras são eventos únicos, que não se repetirão com a mesma cor, sabor, odor, som e textura. Os sentidos emergem em um momento único de encontro, em que fatores complexos se coadunam para formar aquela vida, aquele texto, aquela leitura. Cada perfil é resultado desse momento único de encontro que não se repetirá.

... os momentos de encontro com o Tu se manifestam como episódios singulares, líico-dramáticos, sem dúvida, de um encanto sedutor, mas que, no entanto, nos induzem perigosamente a extremos que debilitam a solidez, já provada, e deixam atrás mais questões que satisfações, abalando nossa segurança. Eles não são só inquietantes, mas indispensáveis. (BUBER, 1979, p. 38)

Para Buber, a relação Eu-Tu nos remete, inevitavelmente à relação com o transcendente, na medida em que, no contato com cada Tu, somos tocados por

11 "A estética da recepção e a crítica da razão impura". Revista de Comunicação e 
um sopro da vida etema. "A relação com o ser humano é a verdadeira imagem da relação com Deus" afima Buber. No encontro Eu-Tu, a lgo acontece no homem...

Às vezes parece um sopro, às vezes, como se fora uma luta, pouco importa: acontece. Ao sair do ato essencial da relação pura, o homem tem em seu ser um mais, um acréscimo sobre o qual ele nada sabia antes e cuja origem ele não saberia caracterizar cometamente. (Ibid., p. 126)

Acredito que esse "algo" também pode acontecer no genuíno encontro de um jomalista com a pessoa que Ihe conta sua história. Afinal, depois de ouvimos uma história que nos foi contada em um momento de autêntico encontro, sentimos que ganhamos algo, paira uma gratidão em nossos corações. Ao mesmo tempo, ganhamos um certo peso, pois somos agora portadores de 'algo' que nos modificou e que nos mobiliza a seguir adiante, seja para que nos transformemos, seja para que esse "algo" se transmita a outras pessoas. Sentimos a necessidade de continuar nossa viagem...

\section{Contribuições de Merleau-Ponty}

Um pintor como Cézanne, um artista, um filósofo devem não somente criare exprimir uma idéia, mas ainda despertar as experiências que vão enraizar em outras consciências. Se a obra é bem sucedida, tem o estranho poder de transmitir-se por

si. Seguindo as indic ações de um quadro ou de um livro, tecendo comparações, tateando de um lado e de outro, conduzido pela confusa clareza de um estilo, o leitor ou o espectadoracaba por reencontrar o que se the quis comunicar. Merleau Ponty

Linguagem. Lisboa, Centro de Estudos de Comunic ação e Linguagens. Junho, 1986. 
Um dos conceitos fundamenta is de Merleau-Ponty em sua fenomenologia da percepção é a reflexividade do corpo. Conforme já foi dito, esse conceito pode ser compreendido como um verdadeiro enigma do corpo, que é ao mesmo tempo vidente e visível. Em decorência dessa concepção, pode-se admitir que cada perspectiva é única, pois eu sou visivelmente incapaz de ocupar o lugar de outra pessoa no mundo. Maso reconhecimento da reflexividade do corpo nos traz outras implic ações.

Visível e móvel, meu corpo está no número das coisas, é uma delas; é captado na contextura do mundo, e sua coesão é a de uma coisa. Mas já que vê e se move, ele mantém as coisas em círculo à volta de si; elas são um anexo ou prolongamento dele mesmo, estão incrustadas na sua came, fazem parte da sua definição plena, e o mundo é feito do próprio estofo do corpo. Estes deslocamentos, estas antinomias são maneiras diversas de dizer que a visão é tomada ou se faz no meio das coisas, de lá onde um visível se põe a ver, toma-se visível por si e pela visão de todas as coisas (MERLEAU-PONTY, 1980, p. 89)

Nesse sentido, ao enxergar meu corpo e o mundo como sendo feitos do mesmo estofo, é como se eu assegurasse às coisas as mesmas caractenísticas que há em mim. Quando vemos as coisas que estão fora de nós, elas também nos vêem. Assim como as coisas que vemos parecem ser inerentes a nós, também nós somos inerentes às coisas que nos vêem. É como se a nossa própria existência estivesse entre as coisas. Um entre que se constrói nesse estranho sistema de trocas que nosso corpo estabelece com o mundo.

É esse entre que me perturba. É ele que faz os conteúdos todos se misturarem a ponto de não sabermos mais o que é nosso e o que é do outro. O entre é mágico. É nele que as transformações acontecem. É nele que a vida se recria. É o entre que causa guerrase que pode trazera paz.

O outro me coloca no entre, pois o entre é um convite para que um pouco do outro entre em nós e para que um pouco de nós entre no outro. Eu e o outro construímosjuntos esse espaço da relação a que denominamos entre. 
O entre é onde nasce as reportagens. E talvez seja onde nos construímos desde sempre...

Mas para chegamos ao entre, precisamos, antes de mais nada, ter essa experiência assustadoramente maravilhosa de sair do confortável lugar onde moramos e percorrer algumas léguas a té um outro espaço, desconhecido e, por isso mesmo, nem tão confortável assim em um primeiro momento. Espaço onde podemos trocarcom o outro, onde podemos promover o encontro.

Se um de nós não estiver disposto a construir esse entre, nós não seremos capazes de nos encontrar. Permaneceremos fechamos em nossos casulos, ruminando nossas confortáveis ou desc onfortáveis impressões de mundo. Esta remos estáticos, impossibilitados de viajar, proibidos de ir e voltar.

Talvez o ma is difícil na construção do entre não seja seus movimentos inicia is e seu durante, mas o seu depois, o retomo. Voltar a si mesmo para lidar com tudo o que houve no entre é muito trabalhoso. Pois já não somos os mesmos depois desse encontro, não podemos mais lidar com nossas próprias questões como lidávamos antes. Nos tomamos um pouco outros para nós mesmos. E isso sempre me assustou e me moveu. Porque ao me descobrir assim, coisa que sempre fui mas que nunca havia percebido, me assusto. No encontro com o outro, afloram questões que sempre estiveram em mim, adomecidas. E é sempre difícil se reconhecer outra, mas também é fantasticamente maravilhoso. É difícil pois há um medo do que poderei encontrar em mim mesma, muito mais do que o que poderei encontrar no outro. Não é o outro que me assusta, maso que ele desperta em mim... Pois o outro se toma meu espelho:

O espelho aparece porque eu sou vidente-visivel, porque há uma reflexividade do sensivel; ele a traduz e reduplica. Graças a ele, o meu exterior se completa, tudo o que eu tenho de mais secreto passa a esse rosto, esse ser plano e fechado que meu reflexo na água já me fazia suspeitar (Ibid., p. 93). 
Para explicar melhor a metáfora do espelho, Merleau-Ponty recorre a uma cena belíssima mostrada por Schilder no livro "The Image and Appearance of the Human Body": “... fumando cachimbo diante do espelho, sinto a superfície lisa e ardente da madeira não somente lá onde estão os meus dedos, mas também nesses dedos gloriosos, nesses dedos apenas visíveis que estão no fundo do espelho" (Ibid., p. 93).

Ou seja, assim como o visível de meu corpo é colocado para fora de mim diante do espelho, também "o invisível de meu corpo pode investir outros corpos que vejo" (p. 93). Indo a lém: da mesma forma que posso transferir meu invisível a outros corpos, outros corpos também podem transferir seus invisíveis para o meu. Assim, "meu corpo pode comportar segmentos extraídos dos dos outros" (p. 93). E os outros corpos comportam segmentos extraídos do meu.

Conclusão: o homem é espelho para o homem. Por isso que me sinto tão atraída por perfis, pois neles há a possibilidade de se estabelecer uma relação próxima diante do entrevistado, uma relação que me coloca no entre, que me leva a me enxergar por meio do outro: "Quanto ao espelho, ele é o instrumento de uma universal magia que transforma coisas em espetáculos, os espetáculos em coisas, eu no outro e o outro em mim" (Ibid., 93).

Todas essas colocações nos remetem à essência da relação que estabeleço com as pessoas que me contam suas histórias. O que fica em mim dessas histórias e transmito ao leitor é o que há naquele ser humano que faz eu me enxergar mais nitidamente. Afinal, diante da infinita complexidade humana, preciso construir meu relato a partir de uma seleção de cenas, situações, frases, descrições etc. Inconscientemente, essa seleção se dá de acordo com o que aquele ser humano ressoa em mim.

É por isso que é impossivel existirem duas matérias idênticas por ma is que os autores dessas matérias sejam colocados diante das mesmas informações. Essas informações são recebidas por cada um de maneira diversa, tocam cada um de um jeito diferente. 
Mas então será que todos esses relatos são falsos? Volto a recorrer a MerleauPonty: “... foi a própria obra que abriu o campo de onde ela aparece numa outra luz, é ela que se metamorfoseia e se toma a seqüência, as reinterpretações intermináveis de que ela é legitimamente suscetível não a transformam senão nela mesma" (p.102).

A obra, exatamente por ser infinita, tal como o como, pode se abrir a inúmeras interpretações, cada uma delas abarcando um aspecto desse infinito. Isso vale para as leituras de mundo que nós, jomalistas, fazemos. Mesmo sendo contraditórias, se essas leituras nasceram de uma relação genuína estabelecida entre o jomalista e a pessoa que lhe contou sua história, elas se complementam. Cada leitura, a seu modo, evidencia uma perspectiva daquele ser humano que se apresentou a jomalista. Uma perspectiva que só foi possível de ser enxergada por aquele jomalista, por meio de seu corpo e mente. Uma perspectiva que nasceu a partir do que o tocou, do que ele enxergou de si no outro.

Mas cada perspectiva é capaz de revelar o todo, poisé arrancada do todo. Por isso as pessoas podem parecer como pessoas nas matérias, mesmo sem que sejamoscapazes de mostrar todasas suas perspectivas.

Por exemplo, só pude escrever o perfil sobre Roberto destacando a faceta de um "homem que não pára" porque essa caracteństica intrínseca de meu personagem sempre me chamou a atenção natural e espontaneamente. Mas é claro que havia muitas outras características que eu poderia ter explorado como ceme de um perfil sobre Roberto. Acontece que foi essa característica, visível não apenas a mim, que me captou ma is fortemente. Porque algo em mim reagiu diante dessa característica. Houve uma ressonância intema ao que acontecia no exterior.

Diante dessa impressão inicial, fui a campo. Durante o convívio com Roberto e a escuta de diversas pessoas de seu entomo, essa impressão foi se consolidando. Eu nunca precisei perguntar para ele, de maneira objetiva:

- Você é um homem que nunca pára? 
Não foi necessánio. Indiretamente, ele e as pessoas de seu convívio diziam isso. Na maior parte das vezes a essência de um personagem se faz ver nas entrelinhas de seu discurso e dos discursos dos outros sobre ele. A essência de um perfil ta mbém está no entre. É construída na relação, não estava lá, dada desde o primeiro momento. Não fui eu que descobri o "homem que não pára", mas foi durante o processo de meu encontro com Roberto que esse homem nasceu.

Mas essa frase, "o homem que não pára", não surgiu após todo o perfil estar pronto, depois de uma análise acurada das caracteństicas de meu personagem. Essa frase apareceu logo nas primeiras linhas do perfil e, aos poucos, foi se revelando para mim sua verdadeira dimensão e o quanto aquela frase permeava todo o texto. Seus múltiplos significados justificavam que aquela construção de palavras permanecesse no topo do que se diz sobre esse personagem ao longo de sua história. E foi só no dia que terminei o perfil que me deparei com uma anotação perdida em meuscademos de campo. Uma frase que Roberto disse a seu médico, Rolando Zani:

—Você sabe que a coisa ma is difíc il é eu fic ar parado, né?

Ou seja, Roberto havia me respondido objetivamente a questão que nunca Ihe fiz. Mesmo que, durante o processo de criação do perfil, eu não tenha me deparado com essa frase solta em meu cademo, ela já estava inscrita dentro de mim. Encontrá-la foi apenas a confimação de algo que já havia se construído em mim. Diante dessa constatação, é inevitável não recorrer a o pensamento do esteta ita lia no Luigi Pareyson.

\section{Contribuições de Luigi Pareyson}

... quando a obra é conseguida, refazendo-se o caminho às a vessase rememorando a a ventura, ele (autor) compreende que só podia fazera obra

daquele modo. 
Luigi Pareyson a fima que o artista cria a partir de um encontro com o mundo e com a matéria e, é a partir desse encontro, que o artista forma e, neste fazer, cria seu modo de fazer e sua legalidade. Ou seja, ao mesmo tempo que cria a obra, o artista cria ta mbém seu modo de fazer e as leis que regem essa construção.

Para ele, a leitura da obra de arte "trata-se não de inventar mas de executar; não de criar mas de recriar; não de darvida mas de despertá-la" (PAREYSON, 2001, p. 203). Assim, a contemplação de uma obra não é uma condição de abandono, inércia, um estado de passividade e esquecimento de si, mas sim o cume de um processo de diálogo do leitor com a obra, de um processo de interpretação "feito de perguntas e respostas, de perguntas que se souberam fazer e de respostas que se souberam captar" (Ibid., p. 207). A contemplação é o prêmio e a recompensa de um esforço.

Como "a obra é indivisível do processo de sua produção, que a precede no tempo" (p. 196), também o intérprete deve considerá-la sob este ponto de vista e "resgatá-la de sua a parente imobilidade para concebê-la no movimento de onde nasceu" (p. 207). Assim, é necessário que os espectador realize a execução da obra para que possa ter acesso à ela, chegando à sua interpretação e à sua ma is completa fruição. Executar e interpretar são atos contíguos para Pareyson, uma vez que, por meio deles, os espectadores realiza m a obra, captando a própria vida pela qual a obra querviver.

Para Pareyson, "a obra exige execução precisamente porque está acabada e perfeita" e "a execução é o único modo de viver da obra" (p. 163). A poesia e a música não existem em sua rea lida de artística em uma página; a pintura não existe em sua realidade artística em uma sala escura. Elas se realizam ao serem lidas, tocadas, olhadas; são dirigidas ao outro, para alguém que as leia, toque e olhe. Alguém que as execute, enfim.

Nesse aspecto, fica a dúvida: a execução da obra segue a subjetividade arbitrária do leitor? A obra se reduz às suas execuções? Superando essa aparente 
dicotomia entre originalidade da obra e subjetividade do leitor, Pareyson aponta para a relação entre obra e execução: "há, a um só tempo, identidade e transcendência: a execução é a própria obra e, ao mesmo tempo, não é senão uma execução dela" (pág.164). Visto que a obra transcende sua s execuções, não podemos reduzi-la a elas. Quanto ao subjetivismo arbitrário, há um engano, porque, na execução bem rea lizada, a lei não é a vontade do executor, mas precisamente a própria obra.

Pareyson aponta também o equívoco de se considerar a multiplicidade das interpretações como erro ou como algo que desvalorize o conhecimento interpretativo. Para ele, a riqueza desse conhecimento, oriundo sim da subjetividade do intérprete, consiste na possibilidade de distintos aspectos da obra serem abordados e isso sempre por meio de processos interpretativos diversos. Afinal, a personalidade é "o único órgão de que o intérprete dispõe para penetrar na obra e colhera sua realidade" (p. 234).

O alcance do intérprete à obra é possível graças à relação de congenialidade ${ }^{12}$ que se estabelece entre obra e leitor, este último envolvendo-se com sua personalidade inteira. Nos dizeres de Pareyson, temos que a interpretação ocorre quando se instaura uma simpatia, uma congenialidade, uma sintonia, um encontro entre um dos infinitos aspectos da forma e um dos infinitos pontos de vista da pessoa: interpretar significa conseguir sintonizar toda a realidade de uma forma através da feliz adequação entre um dos seus aspectose a perspectiva pessoal de quem olha. (p. 226)

É por meio da congenialidade que se estabelece a relação de identidade entre a obra de arte e sua interpretação, sempre lembrando o aspecto inexaurivel dessa última. A unicidade é própria da obra, enquanto a multiplicidade é uma caracteństica da interpretação. A obra, por sua completude, é inexaunivel e sempre permite novas interpretações. Esse caráter múltiplo, infinito do processo

\footnotetext{
${ }^{12}$ De acordo com o Dicionário Aurélio, congenial significa "conforme à índole, ao gênio de alguém, próprio por natureza, nascido ou produzido junto de".
} 
interpretativo, não indicaria uma revelação aproximada da obra, mas antes um perfil inteiro dela. Enqua nto ilumina a obra, a interpretação a possui efetivamente.

A congenialidade trata-se de uma sintonia, um encontro, uma "feliz adequação" entre obra e intérprete. Segundo Pareyson, "a obra fala a quem sabe interrogá-la melhor e a quem se põe em condições de saber escutar sua voz: ela espera ser interrogda de um certo modo para responder revelando-se" (p. 173). O autor afima que "o ideal perfeito de executor é saber escolher bem os próprios autores, saber desfrutar até o fundo as próprias a finidades eletivas, e estender, o mais possível, o âmbito da própria congenia lidade." (p. 237).

Lembrando o trecho em que Pareyson escreve sobre a inspiração: "Na verdadeira arte, a inspiração nunca é tão determinante que reduza a atividade do artista a mera obediência, e o trabalho nunca é tão custoso que suprima a espontaneidade" (p. 195), podemos, do mesmo modo, intuir que: uma interpretação nunca é tão deteminante que reduza a obra a mera obediência ao olhar do sujeito que a interpreta, e o trabalho de interpretação nunca é tão custoso para chegar à obra que suprima a espontaneidade e pessoalidade do sujeito que a interpreta. "A interpretação é sempre, ao mesmo tempo, revelação da obra e expressão do intérprete, e, por isso, objetiva e pessoal a uma só vez, tanto mais fiel quanto mais livre e tanto mais original quanto mais verdadeira" (p. 235).

Enquanto o artista parte do desconhecido (da inexistência de obra) para uma forma (a obra em si), o leitor parte de uma foma (a obra que se apresenta) para o desconhecido (a interpretação que vai se dar). Podemos, assim, compreender que ambos, artista e leitor, agem de acordo com o princípio da formatividade. Assim, a interpretação também é "um tal fazer que, enquanto faz, inventa o porfazere o modo de fazer" (p. 26).

O professor João Augusto Frayze-Pereira, do Instituto de Psicologia da USP, tece paralelos e aproximações entre a estética e a psicanálise. Para ele, é possível compreender a psicanálise de maneira original se pensamos que o trabalho do psicanalista é similar ao de um espectador diante de uma obra de arte. Afinal, o psicanalista pode contemplar seu paciente tal como um espectador contempla 
uma obra de arte. Seguindo a idéia de Frayze-Pereira, acredito que também podemos compreender a relação joma lista/fonte de maneira original se pensa mos que o jomalista pode ser comparado com um espectador, basta que ele olhe para a pessoa que lhe conta sua história como se fosse uma obra de arte.

Quando um jomalista constrói uma história de vida, para que seu trabalho atinja níveis de excelência, é preciso, em essência, chegar a uma interpretação sobre a pessoa de quem se escreve. Levando em consideração a maneira como Pareyson entende o processo de interpretação de uma obra de arte, para interpretar uma pessoa, o jomalista deve fazer um esforço para resgatar essa pessoa de sua aparente imobilidade e concebê-la no movimento de onde nasceu. O jomalista precisa aprender a interrogar sua obra de arte e a escutá-la não de uma maneira mecânica e padronizada, mas da maneira que aquela pessoa espera ser interrogada, para que, assim, ela possa se revelar. Nesse sentido, o jomalista é um etemo aprendiz, pois cada pessoa espera ser interrogada de um certo modo. Só assim é possível captar aquela vida da maneira pela qual ela quer viver.

Uma pessoa não existe na rea lidade jomalística a té encontra rum autor que a saiba interpretar. Um autor que saiba direcionar um de seus infinitos pontos de vista para o encontro de uma das infinitas caractenísticas dessa pessoa. É a feliz adequação entre a perspectiva pessoal do autor e as características da pessoa que possibilita o surgimento de uma autêntica história de vida. É quando se instaura a congenialidade, a simpatia, a sintonia entre duas subjetividades que nasce a histónia que vai ser narrada.

Parafraseando Pareyson, o ideal perfeito de um autor de uma história de vida é saber escolher bem as próprias pessoas que Ihes contarão suas histónias, saber desfrutar a té o fundo as próprias a finidades eletivas, e estender, o mais possível, o âmbito da própria congenialidade. Quando isso acontece, o autor desfruta de uma fantástica liberdade literária, podendo colocar no texto suas impressões pessoais sem receios, pois viu, na prática, o quanto essas impressões são 
compartilhadas com muitas outras pessoas que convivem com aquela personagem.

E o ma is interessante é que não há a penas uma interpretação possível sobre uma pessoa, mas infinitas. No entanto, esse caráter múltiplo do processo interpretativo não indica uma revelação falha sobre a pessoa pois, apesar de não ser possivel a preender todas as facetas de um ser humano, a interpretação de um autor é capaz de revelar efetiva mente essa pessoa se consegue lançar luzes sobre ela. Afinal, tal como uma obra, por sua completude, uma pessoa é inexaunivel e sempre permite novas interpretações. Por isso, uma histónia de vida é sempre, ao mesmo tempo, a revelação da pessoa que está sob foco e a expressão de um autor. A um só tempo, objetiva e pessoal, “tanto mais fiel quanto mais livre e tanto mais orig inal quanto ma is verdadeira".

\section{Contribuições James W. Pennebaker}

If you can get people talk or write about their problems, their health improves. James W. Pennebaker

“Por que as pessoas ao redor do mundo procuram contar suas histórias? Existe algo de urgente para ser confessado? É saudável divulgar nossos pensamentos e sentimentos mais profundos?" Com essas perguntas o professor de psicologia da Universidade do Texas, James W. Pennebaker começa seu livro Opening Up - The Hea ling Power of Expressing Emotions.

Ao longo de suas pesquisas, o professor tem acumulado evidências que sugerem que, ao transformar em linguagem as experiências de nossa vida, efeitos positivos podem ser percebidos em nossa mente e como. De acordo com Pennebaker, quando alguém fala sobre suas questões em um grupo, por exemplo, diz que se sente bem e que aprendeu com isso. Depois de confessar um crime, a mente e o corpo de um criminoso mostram estar relaxados. Quando uma pessoa 
percebe uma ligação entre um evento psicológico e um problema de saúde recorrente, sua saúde melhora.

Esses fenômenos estão relacionados com a retração ou a liberação psicológica exercida por uma pessoa em relação a acontecimentos de sua vida e às sensações produzidas. A pesar de muitos estudos ainda esta rem em anda mento, o professor resume as princ ipa is desc oberta s nos seguintes tópic os:

- A inibição demanda um tra ba lho físico, ou seja, inibir a tiva mente um pensamento, um sentimento ou um comportamento exige um trabalho fisiológico de nosso organismo.

- A inibição afeta não só a saúde a longo prazo como também produz efeitos danosos em fatores biológicos imediatos do organismo como pressão sanguínea, tra nspira ção, respira ção, batimentos ca rdía cos, tensão muscula retc .

- A inibição influencia nossas habilidades mentais. Ao não falar sobre significativos pensamentos e sentimentos associados a um evento, nós não pensamos sobre esse acontecimento de maneira integrativa. Quando não transformamos esses pensamentos e sentimentos em linguagem, somos impedidos de entender e assimilar um evento.

Em contrapartida, várias pesquisas do professor indicam que, ao encarar os sentimentos e os pensamentos associados a um acontecimento, há uma imediata redução nos níveis de estresse de nossos organismo e se, ao longo do tempo, as pessoas continuarem a agir dessa maneira, há uma diminuição geral em todos os níveis de estresse do como. Além disso, encarar sentimentos e pensamentos nos força a repensar os eventos sobre os qua is falamos. E quando passamos algo para uma linguagem, seja ela escrita ou falada, podemos entender melhor nossas experiênciase, finalmente, deixá-las para trás.

Durante a apresentação dos inúmeros resultados obtidos em suas pesquisas, que vão desde estudos com criminosos diante de a parelhos detectores de mentiras até pessoas que escrevem sobre experiências traumáticas como abuso sexual e a morte de um companheiro, Pennebaker pondera que as experiências realizadas em laboratório são eventos únicos. Ou seja, as pessoas que participam dessas 
pesquisas são colocadas em uma situação em que podem divulgar tudo sobre a vida sem qualquer receio das conseqüências. Em muitos casos, essa situação é muito mais segura do que falar com um amigo, com um psicoterapeuta, ou com um parente, por exemplo. E acrescento: mais seguro também do que falar com um joma lista. Embora reconheça essas diferenças entre a vida real e a situação criada em laboratório - muito mais favorável para que as pessoas se abram -, o professor se impressiona com o grau em que os participantes falam livremente sobre suas questões.

People seem to have an underlying urge to confess. Inhibition is not pleasant for most of them. Although many have been holding back their personal secrets for months or years, they are still eager to disc uss them. Wether there is a true biological need to confess is certainly debatable. In any case, people are open to disclosing sides of themselves that are potentially humiliating, shameful, or downright illegal. (PENNEBAKER, 1997, p. 56)

Faço coro com Pennebaker: também me impressiono com a facilidade que as pessoas falam sobre questões íntimas para um jomalista, com todas as implicações que há neste caso como, por exemplo, a publicação dessas informações. É muito comum, durante a apuração de uma história de vida, quando se estabelece uma relação de confiança entre jomalista e fonte, nos deparamos com situações em que, depois de revelar algo sobre sua vida, o protagonista volta atrás e pede ao jomalista que não coloque no texto determinada informação. Isso não aconteceu durante a produção do perfil de Roberto.

Masjá vivi uma situação assim, durante a elaboração do perfil de Obeny, um doceiro de São Paulo. São casos em que a fonte se envolve de tal forma naquela relação que acaba se esquecendo, em alguns momentos, de que está diante de um jomalista e não de um amigo. Nessas situações, o jomalista precisa estar ciente de que, em uma história de vida, o objetivo é compreender o ser humano que está diante de nós e não denunciá-lo. Se soubemos lidar com as palavras de maneira adequada, é possível até mesmo dizer ao leitor que algo não pode ser dito. Isso 
sem ofendermos e nos indispormos com a pessoa que nos relatou sua história. Afinal, é preciso ter em mente que a narrativa pertence ao autor, mas a história ao protagonista. No caso do perfil de Obeny, tentei resolver a questão da seguinte forma:

Prove dessas palavras, sabendo que são nutridas por uma vida que não pode se revelar por completo. Nenhuma vida cabe por inteira no papel, na panela. Há também que se escolher quem está pronto para receber o que temos para doar. Muitos ainda precisam de um preparo, pois não compreenderiam a doçura do que Ihes é dito. Portanto, é preferivel revelar somente o que é do ser, isso despertará outros seres. ${ }^{13}$

Em outros casos, a pesar do protagonista não nos dizer nada sobre a não publicação de determinado fato, o próprio jomalista percebe que seria constrangedor divulgar certa informação. Isso é comum em relatos de histórias traumáticas. Aqui, cabe ao jomalista e a fonte decidirem qual o melhor caminho seguir, lembrando que há sempre uma solução possível, sem a necessidade de deixar de informar o leitor nem de ferir os sentimentos da pessoa que nos contou sua história. Durante a escrita do perfil de Ivani, uma cobradora de ônibus, encarei essa dúvida: exponho totalmente a protagonista ou escrevo a narrativa de um jeito em que a situação traumática vivida fique implícita? A dúvida se dissipou quando o professor Edvaldo Pereira Lima me deu uma grande dica: tenha delicadeza, coloque-a em primeiro lugar. Resolvi seguir a dica:

- Isso é coisa de vagabunda!

O pai estava furioso, gritava feito um doido. Ivani só conseguia chorar. Ela tinha acabado de chegar da academia e ele, que nunca havia se importado com o sonho da garota - sequer fazia questão de saber que ela tinha um sonho - decidira

13 "Navegante de açúcares e afetos", perfil produzido no segundo semestre de 2003 para a disciplina Jomalismo Literário Avançado e Histórias de Vida: Uma Proposta Tra nsd isc iplinar. Disponível em: http://www.textovivo.com.br 
acabar com a "sem-vergonhice" de Ivani de uma vez por todas. Parecia querer a garota só para si. E ai dela se voltasse a pisarnaquele lugar, ele era capaz de matála e já aproveitaria para acertar as contas com a mãe, que vivia escondendo os desa tinos das filhas...

Acostumada às ameaças e às cenas de violência cotidianas, Ivani vivia agora um drama diferente. As pancadas que ele costumava dar doíam menos do que aquele impedimento. Ela nunca sofreu tanto como naquela noite, em que viu o sonho estático no chão. A desilusão foi tão grande que os pés não tiveram a coragem de ir à academia dizeradeus. ${ }^{14}$

O fato é que os estudos de Pennebaker nos levam a pensar o quanto falar sobre nossas vida pode ser importante e até mesmo saudável. Ao transpor em linguagem sentimentos e pensamentos a respeito de uma situação, Pennebaker diz que alteramos a maneira como representamos e compreendemos aquele acontecimento.

Voltando à frase dita por Cláudia durante a entrevista para o perfil de Roberto - em que diz que nunca havia olhado para aquela questão da maneira como lhe apresento -, penso no quanto o trabalho de apuração de uma história de vida coloca o jomalista diante de um papel que vai muito além da produção de uma leitura possível do mundo. Ao estabelecer um relacionamento próximo com uma fonte, estamos promovendo também uma releitura sobre aquela vida que nosé contada e, porque não, ta mbém relendo nossa própria vida.

Ao longo das produções dessas histórias, fui percebendo que, cá e acolá, surgem frases similares à dita por Cláudia. Algumas falas de meus entrevistados demonstram o quanto a produção desse tipo de narrativa mexe com a vida, a mente e, levando em consideração as pesquisas de Pennebaker, o corpo das pessoas:

- "Nunca pensei sobre isso dessa forma".

- "Falando agora, parece tão fácil mas, na época, foi muito difíc il".

14 "A dançarina da metrópole", perfil escrito para a Tese de Doutorado de Andrea Pacetta de Amuda Botelho. 
- "É a primeira vez que estou pensando a respeito desse assunto, a qui, com você."

Ao trazer à tona situações, imagens, sensações, entre outras tantas recordações, vividas há muitos anos ou há alguns segundos, somos realmente capazes de percebê-las de um outro jeito. Nasce uma nova perspectiva sobre algum aspecto da vida da gente, o que acaba, na maioria das vezes, lançando-nos para a abertura de portas que, antes, estavam trancadas. E, atrás de cada porta, há sempre mais e mais a ser descoberto.

Para Pennebaker, a linguagem é também uma ferramenta que simplifica nossas experiências. Quando contamos várias vezes uma mesma história para diferentes pessoas, percebemos que, inicialmente, existem muitos detalhes: sons, emoções, pensamentos tomam conta de nossa mente e estão presentes na forma como falamos sobre aquela situação. Ao longo do tempo, aquela experiência vai se tomando mais concisa, com um claro começo e fim. "The act of repeatedly telling about our experience resulted in both an organization to the event and a summarizing of it" (Ibid., p. 97).

No perfil de Roberto, percebi o quanto as histónias que ele conta sobre sua infância e demais situa ções de sua vida são extremamente concisas. A maioria das cenas que reconstruí no texto foram baseadas nos relatos das outras pessoas que ouvi: Rosely, Cláudia, Anderson e Margaret. Talvez seja porque uma das principa is característic as de Roberto, tanto nas palestras quanto nas reuniões da Editora e em seus livros, é exatamente narrar histórias de sua vida. Ele usa sua própria vida como matéria-prima. Ao contar e recontar suas histórias, ele as toma cada vez mais organizadas e concisas. O próprio Roberto conta que seu imão mais velho, Gilberto, certa vez comentou que, ao ouvir Roberto falar sobre fatos da infância em suaspalestras, quase não os reconhece.

Outro aspecto interessante em relação às recordações que temos de nosso passado: Pennebaker cita um estudo que mostra o quanto as pessoas casadas se tomam depositánias das memórias de seus cônjuges. Por exemplo, se a esposa tem mais facilidade para lidarcom as finanças, provavelmente ela será a pessoa que se lembrará de quando o casal comprou a primeira casa e demais situações 
relacionadas à vida financeira. Por outro lado, pode serque o marido tenha maior facilidade para se lembrar dos filmes a que o casal assistiu.

Pensando nisso, é fundamental que o autor de uma história de vida, durante a elaboração de um relato sobre uma pessoa casada, tente conversar com o companheiro de seu personagem. O objetivo não é confrontar as versões de um fato entre os cônjuges, mas obter o maior números possível de detalhes sobre acontecimentos vividos pelo casal. Por mais que tenham passado pela mesma experiência, cada um se lembrará disso de uma maneira diferente.

Com relação às conseqüências benéfic as de falar sobre nossos sentimentos e pensa mentos, Pennebaker a fima que não são a penas os eventos tra umátic os que precisam ser confronta dos. Apesar das emoções e acontecimentos que nos trazem euforia, alegria, orgulho e felicidade estarem nomalmente associadas à boa saúde, ele afima que isso depende do que fazemos com essas experiências positivas e os sentimentos por elas gerados. "As with traumas, positive events should be talked about and openly expressed. Actively holding them back is yet another form of inhibition - with all the attendant health risks" (Ibid., p. 124).

Assim, é inevitável pensar o quanto, historicamente, a maioria das culturas tem buscado desenvolver mecanismos que permitem às pessoas falar sobre seus sentimentos e pensamentos mais profundos de uma maneira segura. Para o professor, "people have formed social institutions that encourage confession because they have a need to disclose and understand the intimate sides of themselves" (p. 181). Por isso, os ritos de confissão estão intimamente ligados ao predomínio de sistemas de crenças religiosas, polític as etc. Tribos, religiões e grupos políticos que encorajam publicamente a confissão garantem que seus seguidores end ossem entusiastic a mente seus valores.

Ou seja, a o estabelecer um relacionamento com as pessoas que lhes contam suas histónias, o jomalista pode ocupar um espaço especialmente importante, atendendo a uma demanda ancestral que os seres humanos têm por contar suas histórias. Um espaço que, na contemporaneidade, com o enfraquecimento das instituições, parece ser cada vez ma is nec essá nio ser preeenchido. 


\section{Hora do desembarque}

E é nesse sentido que se dão as viagens, isto é, como experiência propriamente dita, como abertura indetermina da a o outro, a o porvir, que exige do viajante distanciamento não porque este se desloca entre lugares distantes, masporque se autodiferencia e transforma seu mundo. 15 João Augusto Frayze-Pereira

É essa viagem da abertura indeterminada ao outro que os jomalistas poderiam estabelecer com as pessoas que Ihes contam suas histórias. Uma experiência que esfumaça as posições deteminadas de sujeito e objeto, de ouvinte e contador. Encarada como "complexa autodiferenciação", a relação estabelecida é troca de experiências e de "lugares":

- o jomalista que ouve, às vezes, se transforma no contador que enuncia um disc urso. Além de suas próprias memórias emergirem, na medida em que escuta o outro, ele também recompõe o que ouviu para fazer perguntas e estar certo de que compreendeu o dito. Indo mais longe, na própria maneira de se relacionar com o contador, o joma lista carrega seu passado, seu presente e, por que não, o futuro...

- a fonte que enuncia, às vezes, se transforma no ouvinte que escuta atento a o questionamento, que silencia para pensar, para descansar, para falar aquilo que não consegue (ou não quer) marcar com palavras. Em última a nálise, o conta dor é ta mbém um ouvinte de suas próprias histónias.

$\mathrm{Na}$ interação constante entre essas duas subjetividade, pode acontecer muito mais do que uma simples coleta de informações. Duas existências podem ser relidas, revistas, repensadas, recordadas. Há, aqui, um terreno propício para transformações, as quais não se restringem ao domínio jomalista-fonte, podendo alcançar a té mesmo o leitor do texto fruto desse processo...

\footnotetext{
15 FRAYZZ-PEREIRA, J oão Augusto. Sobre o trá gic o, ma is a inda. In: A viagem: da litera tura à psic a nálise, p. 12-13.
} 
"O narrador conta o que ele extrai da experiência - sua própria ou aquela contada por outros. E, de volta, ele a toma experiência daqueles que ouvem sua histónia"16. A experiência vivida que se dá durante a relação estabelecida entre jomalistas e fontes é o que deve guiar as palavras futuras do jomalista. Ele, ao colocar essa experiência em palavras, toma-a conhecida para osoutros e também para si.

Para que isso aconteça, a atitude dos jomalistas na apuração de informações para a elaboração de uma história de vida precisa ser diferenciada. 0 jomalista não deve buscaro pretenso distanciamento "objetivo" da pessoa que the conta sua história, mas, a c contrário, uma proximida de que permita compreensão. Um compreender que não se restringe ao relato que the chega aos ouvidos, que também engloba toda a radiância de vida que se coloca diante de seus poros.

É a tentativa do impossivel: olhar a vida que se apresenta como se fosse nossa própria vida, como se pudéssemos viver sob a pele do "outro". E a rea lização do possível: olhar a vida que se apresenta com compaixão, assumindo que se está disposto a "sofrer junto" com aquela pessoa - "com" quer dizer companhia e paixão, sofrer -, lembrando-se que isso implica que haverá também o compartilhar de inúmeros somisos. O que só é possível se o autor não agir com distanciamento: "Narrar é também sofrer quando aquele que registra a narrativa não opera a ruptura entre sujeito e objeto" 17

Pennebaker explica que, da mesma forma que há efeitos sobre o nosso organismo quando falamos sobre sentimentos e pensamentos relacionados a acontecimentos de nossa vida, existem também efeitos sobre o organismo de quem escuta essas histónias. "Being confronted by someones else's trauma can be na emotional burden. Indeed, listening to accounts of traumatic experiences may pose a health risk" (Op. Cit., p. 117). Por isso ele explica que psicólogos e profissiona is que atuam em atividades que ajudam outras pessoas costumam passar um ou mais anos sob a supervisão de um profissional experiente. Esse período

\footnotetext{
16 Marilena de Souza CHAUÍ, Os trabalhos da memória. In: Memónia e Sociedade, p. 14.

17 Marilena de Souza CHAUÍ, Os trabalhos da memória. In: Memónia e Sociedade, p. 13.
} 
de supervisão serve para que as pessoas aprendam a lidar com as histórias que ouvem e os segredos que the são confidenciados. Mas ele reconhece que os psicólogos são muito pouco treinados na arte de ouvir os problemas dos outros. Imagine então os jomalistas...

Acredito que para que possamos desenvolver melhor a capacidade dos joranlistas de ouvir as histórias das pessoas precisańa mos realizar um trabalho ma is amplo com os estudantes de jomalismo. Levar às salas de aula a prática de confrontar os sentimentos e os pensamentos que nós temos quando nos relacionamos com outros seres humanos. Discutir abertamente o signific ado de se deixar tocar e ser tocado pelas histórias de uma outra pessoa. Nesse caso, não se trata de treinar os estudantes com técnicas pré-concebidas, mas de levá-los a compreender a profunda experiência do Eu-Tu. Fazê-los perceber que o pressuposto para que possamos estabelecer uma relação genuína é a reciprocidade.

Sarah Yakhni, em sua Dissertação de Mestrado "Eu e o Outro no Filme Documentánio: uma Possibilidade de Encontro", diz: "O fato do realizador se colocar de maneira integrada frente ao outro instaura a possibilidade de reciprocidade, no sentido de se estabelecer um vínculo que tenha como base a confiança mútua e uma abertura para a entrega" (p. 27). Na citação, o realizador é o jomalista e sua atitude é realmente muito importante para que um vínculo genuíno com a fonte possa ser estabelecido. O jomalista precisa se colocar como um parceiro de sua fonte, como um autêntico participante daquele diálogo.

Não adianta apenas estar receptivo para a presença do outro, ou deixá-lo à vontade dentro da situação colocada pela filmagem, é preciso estar plenamente presente e disposto a sair de si, face ao outro e ao mundo, numa atitude de abertura, de deixar se manifestar em seu próprio centro dinâmico (YAKHNI, 2001, p. 29) 
Ou seja, precisamos ter coragem e estar dispostos a também compartilhar um pouco de nossa vida com aquela pessoa que compartilha um pouco de sua vida com a gente. Lembro-me de que, no iníc io de minha entrevista com Anderson, ele me fez uma série de perguntas sobre minha trajetória profissional, minha família, meus sonhos. Apesar de trabalharmos na mesma empresa, nunca tivemos a oportunidade de estabelecer um contato pessoal mais próximo. Por isso, tentei reponder a sua perguntas da maneira mais aberta e sincera que pude, pois compreendi o quanto era importante aquelas palavras para que pudéssemos estabelecer um verdadeiro vínculo. Em muitos casos, é a partir de um bate-papo assim que as pessoas se revelam diante de nós e somos surpreendidos por relatos que jama is imaginaría mos ouvir da boca daquele ser humano.

In our lives, we faced a number of upsetting events that we want to discuss with someone. Divulging our deepest feelings can forge a powerful and lasting bond with others. Several experiments, for example, suggest that when one person disc loses a secret to another, the other person often reciprocates. The interpersonal cycle of self disclose, according to social psychologists Irwin Altman and Dalmas Taylor, works much like the therapeutic dance between therapist and client. If neither person is rebuffed during the dance, the nature of disclosures become more intimate over time. Once the cycle is in place, the two people will have established a stable and trusting relationship that will provide an outlet for disclosure in case of future traumas (PENNEBAKER, 1997, p. 115).

Sarah e Pennebaker nos dão algumas pistas que visam auxiliar na criação dessa dança interpessoal, vale a pena lembrar-se daspalavras de Buber. não basta procurar, pois um encontro se dá pela graça. Ou seja, por mais que nos esforcemos, isso não é uma garantia de que um encontro se dará. Na visão de Sarah:

A abordagem dialógica requer uma mudança de comportamento frente ao outro no sentido de se desfazer de expectativas e noções preconcebidas à seu respeito e caminhar em direção ao que Buber aponta como o principal pressuposto para o 
surgimento de uma conversação genuína - que cada um veja seu parceiro como precisamente é, descobrind o o outro enqua nto totalidade, unicidade e concretude, sem abstrações que o reduzam. (p. 25)

Para Pennebaker, as pessoas ficam mais à vontade para falar se sentem segurança em seus interlocutores, se percebem que não serão julgados ou criticados pelo que falarem. Quando fiz meu Trabalho de Conclusão de Curso com Dulcinéia, uma ex-presidiária, lembro-me claramente do que ela me disse na última entrevista:

Foi aí que eu vi que o seu traba lho era legal: o que você estava querendo era o lado mais humano. Você não estava preocupada exatamente se eu continuava roubando ou tinha deixado de roubar, não era com isso que você se preocupava. Você queria sabero lado humano: como eu estava me sentindo com o que eu tinha passado. Independente de eu estar trabalhando ou não. Independente de qualquer coisa. Isso é legal (...) E o que eu percebi em você é que você estava a fim de trabalhar a parte humana, resgatar esse lado humano, que se perde mesmo, que as pessoas a niquilam, pisam em cima. Deus me livre sair por aí falando que eu sou expresa, imagina! Porque eles enxotam a gente mesmo, um puta preconceito. Se você veio pra isso, pra trabalhar esse meu lado humano, então, é um trabalho super legal. 18

Tanto essa questão do não julgamento é importante que Pennebaker ressalta o quanto é comum semos supreendidos em um avião por um passageiro que passa a nos revelar seus segredos mais íntimos. Taxistas, cabeleleiros, prostitutas, bamens e demais profissionais convivem diariamente com essa realidade. 0 professor afima que, a o estar livre de qualquer recriminação, a pessoa acaba se sentindo à vontade para se soltar, pois sabe que provavelmente não haverá qua lquer consequência na quelas revelações.

18 Depoimento de Dulcinéia Pozo a Denise Casatti em abril de 2001. 
Nesse sentido, é inevitável que nós, jomalistas, tenhamos de lidar com o incômodo de semos jomalistas. A não ser que façamos uma opção por não revelamos a nossa identidade - o que, acredito, deve ser uma atitude tomada apenas em situações em que essa é a única a ltemativa que temos para obter uma informação socialmente relevante -, precisaremos levar em conta que, dependendo da nossa fonte, o estabelecimento de vínculo será ma is dific ultoso. De acordo com Pennebaker, os comentánios de uma pessoa podem ser afetados pelas expectativas de seu ouvinte. Dependendo da audiência, as pessoas podem consciente ou inconscientemente mudar a maneira como explicam e interpretam seus sentimentos e pesamentos.

Além disso, as motivações de uma pessoa para nos revelar seus sentimentos, pensamentos e segredos nem sempre são "puras". Muitos interesses podem estar por trás de uma revelação. Mas é claro que isso também vai depender do tipo de contato que o jomalista estabelecer com a fonte. Se houver, como diz Pareyson, uma congenialidade, é bem pouco provável que aconteça algum tipo de manipulação. Aliás, quando há um encontro Eu-Tu, a manipulação é uma palavra fora de cogitação...

A questão que se coloca agora é: como construir uma narrativa da contemporaneidade que reflita esse encontro com o outro? Como diz Ana Taís Martins Portanova Barros, o desafio é "construir uma narrativa complexa, emancipatória, que não deslize para a arrogância de um repórter que dita verdades sobre o mundo, nem no falso objetivismo de querer reproduzir o mundo, mas que reflita a relação homem/mundo, isto é, o imaginário (p. 159).

A meu ver a narrativa mais coerente com essa nova perspectiva de jomalismo e da relação com o outro, é aquela que seja capaz de abarcar o conceito de formatividade de Pareyson. Ou seja, uma narrativa que surja do contato do jomalista com as palavras (a matéria-prima com que lidamos) e com as pessoas que narram suas histórias a ele e, a partir desse encontro, ele escreva de um modo que, enquanto escreve, invente seu modo de fazere sua legalidade. É só assim que uma história de vida ganha a cara do personagem que a inspira. 
Assim, se ele é leve, espontâneo, sensível, brincalhão, como o Roberto, o texto também deve, de alguma maneira, refletir essas caracteństicas, pelo menos em a lgumas passagens. Isso, sem deixar de lado o estilo na rrativo do autor.

Mas essa "cara" do texto surge naturalmente se mergulharmos na história e compreendermos a fundo o personagem. No "diário de bordo" que criei durante essa viagem que empreendi a esse outro ser humano chamado Roberto, escrevi, no dia 29.12:

A sensação boa do parto. Antes, angústia, dúvidas, insegurança. Dá medo ver aquele tanto de informação desorganizada, disforme. Mas quando coloco a mão na massa é como se aquilo tudo fosse, aos poucos, ganhando uma vida própria. As conexões começam a surgir quase que naturalmente. Há todo um trabalho mental e consciente de seleção das informações, mas há também alguns processos inconscientes acontecendo. Algumas idéias que simplesmente caem como uma luva sobre o papel. O difícil é começar, parece que há um embate intemo, quase como uma gestação que não quer chegar ao fim, ao témino, mas depoisque esse momento de parto se inicia parece que algo é disparado em minha mente e as coisas se desenrolam de um jeito muito mais fácil e leve e prazeroso. Espero que o processo continue assim, fluido, feliz e cheio de aprendizado.

Parece que este trecho explica um pouco o meu modo de produção, um tanto difícil de ser explicado, já que é um modo que surge no fazer. E como nenhum ser humano é igual ao outro, nenhum modo de fazer uma histónia de vida pode ser igual a o outro. Cada história de vida nos motiva a utilizar detemina dos recursos. Se falamos sobre um personagem que nos conta tudo em forma de diálogo, acabamos incomorando isso ao texto. Se lidamos com alguém como Roberto, acabamos sendo levados a um verdadeiro bate-papo com o leitor e com os personagens a o longo do texto.

Mas o que acho mais importante, independentemente do estilo que seja adotado, é sempre deixar muito clara a posição que nós, jomalistas, ocupamos na narrativa. E isso pode ser feito de inúmeras formas. No caso do perfil de Roberto, 
optei por deixar nossa relação transparecer ao longo do texto, vou mesclando minhas experiências, às cenas que presenciei e às histórias que ouvi.

Por isso, julguei adequado, nesta Dissertação, em que falo sobre relações, produzir o perfil de Roberto. Trata-se de um texto que traz em si próprio a narrativa de inúmeras relações. Por isso, foi natural que, dentro do perfil, eu também deixasse o leitora parda relação que estabeleci com Roberto, do nosso convívio na Editora, dascenas que presenciei. Foi a maneira que encontrei, nesse caso, de levaro leitor a compreender a minha posição para que ele pudesse se colocar diante de nós! De todos nós que somos personagens no texto.

O que fiz, no texto sobre Roberto, foi englobar relatos dos bastidores do perfil no próprio perfil. Mesclei meu making of à narrativa. No entanto, há muitas outras maneiras de ser transparente com o leitor, de mostrar a ele como a apuração foi feita, o lugar que o jomalista ocupa na narrativa, enfim... Uma delas é fazer o making of da narrativa em separado. Essa é uma técnica bastante incentivada pelo professor Edvaldo Pereira Lima. O que há de mais importante nessa técnica é que ela faz o jomalista pensar sobre sua própria produção, faz o jomalista refletir sobre seu modo de fazer.

Na minha opinião, essa é a questão-chave para que os jomalistas possam de fato esta belecer relações ma is próximas com as pessoas que contam suas histórias a eles. É só por meio da auto-reflexão que deixamos de ter medo de ir ao encontro do outro, que rompemos as barreiras que nos fazem fic ar presos em nossos casulos. Pois quando refletimos sobre a nossa produção, percebemos que não há nada mais maravilhoso do que o encontro com o outro, que não há nada de "errado" nisso.

O que é anti-ético é nos escondemos atrás da falsa idéia da objetividade. O que faz o jomalismo ficar cada dia mais doente, sem forças para reconstruir seus pilares, é o não se confrontar com os sentimentos e pensamentos que o permeiam. Está na hora de semos mais saudáveis, de lidarmos melhor com nossos próprios sentimentos e pensamentos para poder lidar melhor com o outro e ta mbém com os textos que surgem desses encontros. É essa a viagem que precisamos empreender. 
O jomalismo é uma atividade de contínuo mergulho na alteridade. Isso significa comunicação de ser humano para ser humano. A pretensão de explicar o real se esvai, ficando a angústia de compreender o desejo mítico do outro. A reportagem daí nascida não servirá para explicar o mundo, e sim para dizer um pouco do seu mistério. (BARROS, 2003, p. 211) 


\section{Referências Bibliográficas}

BARROS, Ana Ta ís Martins Porta nova. Sob o nome de real: ima ginários no jo ma lismo e no cotidiano, 2003. Tese (Doutora do em Ciências da Comunicação) Universida de de São Paulo. São Paulo.

BOSI, Ecléa. Memória e sociedade: lembrança de velhos. São Paulo: Companhia das Letras, 1999.

BUBER, Martin. Eu e Tu. São Paulo: Cortez \& Mora es, 1979.

CAMPBELL, J oseph. O poder do mito. São Paulo: Palas Athena, 1990.

CANC UNI, Néstor García. Do primitivo ao popular. teorias sobre a desigualda de entre as culturas. In: As c ulturas populares no capitalismo. Sã o Pa ulo: Bra siliense, 1983.

CHRISTOFOLEIII, Rogério. A medida do olhar objetividade e a utoria, 2004. Tese (Doutorado em Ciências da Comunic ação) Universidade de São Paulo. São Paulo.

CRUZ, Maria Teresa. A estética da recepção e a crítica da razão impressa. Revista de Comunicação e Linguagens, Lisboa, n. 3, Centro de Estudos de Comunic ação e Linguagem, jun. 1986.

DEIIENNE, Marcel. Os mestres da verdade na Grécia Arcaica. São Paulo: Jorge Zahar Editor, 1988.

FRAYZ⿱一⿻上丨-PEREIRA, J oão Augusto. A tentação do ambíguo: sobre a coisa sensível e o objetivismo científic o: estudo e crítica. São Paulo: Ática, 1984.

Olho d'água: arte e loucura em exposição. São Paulo:

Esc uta, 1995.

GOSWAMI, Amit. A janela visionánia: uma guia para a iluminação por um físico quântic o. São Paulo: C ultrix, 2003.

GRECO, Milton. A aventura humana do real ao imaginário. São Paulo: Cultrix, 1987.

J UNG , C. G. Sincronic idade. Petrópolis: Editora Vozes, 2005.

KON, Noemi Moritz. A viagem: da literatura à psicanálise. São Paulo: Companhia das Letras, 2003.

LEENHARDT, J acques; PESAVENTO, Sandra J. (Orgs.). Disc urso histórico \& narrativa literária. Campinas: Editora da Unicamp, 1998. 
LE GOFF, J a cques. "Memória-História”. In: Encic lopédia Einaude. Volume 1, Portugal, Imprensa Nacional-Casa da Moeda, 1984.

UMA, Edvaldo Pereira. Página ampliadas: o livro-reportagem como extensão do jomalismo e da literatura. São Paulo: Manole, 2004.

A inteligência da complexidade. São Paulo, Peirópolis, 2000.

Peirópolis, 1998.

(Org.). Criatividade e novas metodologias. São Paulo: Editora Fundação

J omalismo Literánio no cinema. Portal TextoVivo - Narrativas da

Vida Real. Disponível em: www.textovivo.com.br. Acesso: 10/01/2005

Registros breves para uma histónia futura. Portal TextoVivo -

Narrativas da Vida Real. Disponível em: www.textovivo.com.br. Acesso: 25/09/2005

Nanativa nos J omais: A Experiência Americana (parte 2). Portal TextoVivo - Na rrativas da Vida Real. Disponível em: www.textovivo.com.br. Acesso: $19 / 11 / 2005$

LUDUVIG, Mônica Martínez. Jomada do herói: a estrutura narrativa mítica na construção de histórias de vida em jomalismo. 2002. Tese (Doutora do em Ciências da Comunicação). Universida de de São Paulo. São Paulo.

MEDINA, Cremilda de Araújo. Entrevista, o diálogo possível. São Paulo: Ática, 1990.

Paulo: Summus, 2003.

A arte de tecer o presente - narrativa e cotidiano. São

"Jomalismo e Epistemologia da Complexidade". In: MEDINA, C. (org.) Novo Pacto da Ciência. Anais do 10 Seminánio Transdisciplinar. São Paulo: ECA-USP, 1991, pp.193-205

MERLEAU-PONTY, Maurice. Fenomenologia da percepção. São Paulo: Martins Fontes, 1999.

Abril Cultural, 1980.

. Textos selecionados (Coleção Os Pensadores). São Paulo:

MITC HELL, J oseph. O segredo de J oe Gould. São Paulo: Companhia das Letras, 2003.

MODERNEL, Renato. A notícia como fábula: o entrelaçamento da ficção com a realidade no texto jomalístico, 2004. Dissertação (Mestrado em Ciências da Comunic ação) Universidade de São Paulo. São Paulo.

MORIN, Edgar. A sociologia do Microssocial ao Macroplanetánio. Lisboa, Public ações Europa-América, 1998 
NOVAES, A. et al. O Olhar. São Paulo: Companhia das Letras, 1988.

PAREYSO N, Luigi. Os problemas da estética. São Paulo: Ma rins Fontes, 2001.

PATRíC IO, Pa tŕc ia. Tirando o manual do automático: do mapa objetivo ao temitónio transubjetivo nos caminhos do Jomalismo, 2002. Dissertação (Mestrado em Comunic ação Social) Universidade de São Paulo. São Paulo.

PENNEBAKER, James W. Opening up: the healing power of expressing emotions. Nova York: The Guilford Press, 1997.

REA, Silvana. Transformatividade: a proximações entre psicanálise e artes plásticas: Renina Katz, Carlos Fajardo, Flávia Ribeiro. São Paulo: Annablume/Fapesp, 2000.

RESTREPO, Luis C a rlos. O direito à temura. Petrópolis: Vozes, 2000.

REZTNDE, Antonio Muniz de; G ERBER, Ignácio. A psicanálise "atual" na interface das “novas" ciências. São Paulo: Via Lettera Editora e Livraria, 2001.

SAIANI, Cláudio. Jung e a Educação: uma a nálise da relação professor/aluno. São Paulo: Esc rituras Editora, 2003.

SANTOS, Boaventura de Souza. Introdução a uma ciência pós-modema. Rio de J aneiro: Graal, 1989.

THOMPSON, Paul. A Voz do Passado. Rio de J aneiro: Paze Terra, 1992.

VARGAS, Raul Hemando Osorio. A reportagem literánia no limiar do século 21: o ato de reportar, os jovens narradores e o Projeto São Paulo de Perfil, 1998. Dissertação (Mestrado em Ciências da Comunic ação). Universidade de São Paulo. São Paulo.

VILAS BOAS, Sergio. Biografia \& Biógrafos: jomalismo sobre personagens. São Paulo: Summus, 2002.

. Perfis e como escrevê-los. São Paulo: Summus, 2003.

. J omalistas-biógrafos: uma expressão de intercâmbios. Portal

TextoVivo - Na rrativas da Vida Real. Disponível em: www.textovivo.com.br. Acesso: $14 / 08 / 2005$

WOLFE, Tom. Radical chique e o novo jomalismo. São Paulo: Companhia das Letras, 2005.

TALESE, Gay. Fama e Anonimato. São Paulo: Companhia das Letras, 2004. 
YAKHNI, Sarah. Eu e o Outro no Filme Documentánio: uma possibilida de de encontro, 2001.Dissertação (Mestrado em Multimeios). Unicamp. Campinas. Disponível em: http://bocc.ubi.pt/pag/yakhni-sarah-eu-outro-documentario.html. Acesso: 2/12/2005. 